This report has been reproduced directly from the best available copy.

Available to DOE and DOE contractors from the Office of Scientific and Technical Information, P.O. Box 62, Oak Ridge, TN 37831; prices available from (615) 576-8401, FTS 626-8401.

Available to the public from the National Technical Information Service, U.S. Department of Commerce, 5285 Port Royal Rd., Springfield, VA 22161.

This report was prepared as an account of work sponsored by an agency of the United States Government. Neither the United States Government nor any agency thereof, nor any of their employees, makes any warranty, express or implied, or assumes any legal liability or responsibility for the accuracy, completeness, or usefulness of any information, apparatus, product, or process disclosed, or represents that its use would not intringe privately owned rights. Reference herein to any specific commercial product, process, or service by trade name, trademark, manufacturer, or otherwise, does not necessarily constitute or imply its endorsement, recommendation, or favoring by the United States Government or any agency thereot. The views and opinions of authors expressed herein do not necessarily state or reflect filose of the United States Government or any agency thereot. 
ORNL/TM-10071/R3

Dist. Category UC-520

Engineering Technology Division

\section{COST ESTIMATE GUIDELINES FOR ADVANCED NUCLEAR POWER TECHNOLOGIES}

J. G. Delene

C. R. Hudson II

Date Published - May 1993

This document contains information of a preliminary nature. It is subject to revision or correction and therefore does not represent a final report.

Prepared by the

OAK RIDGE NATIONAL LABORATORY

Oak Ridge, Tennessee 37831 managed by

MARTIN MARIETTA ENERGY SYSTEMS, INC.

for the

U.S. DEPARTMENT OF ENERGY

under Contract No. DE-AC05-840R21400 


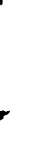




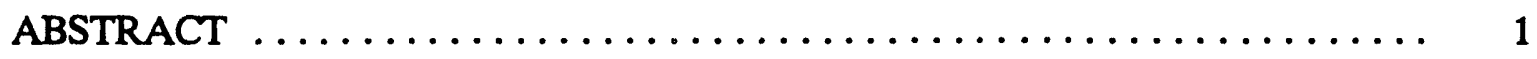

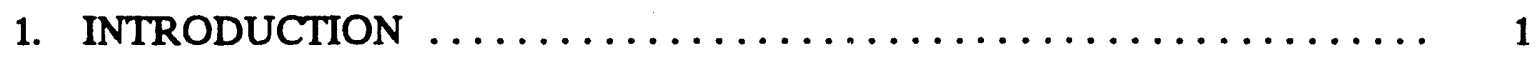

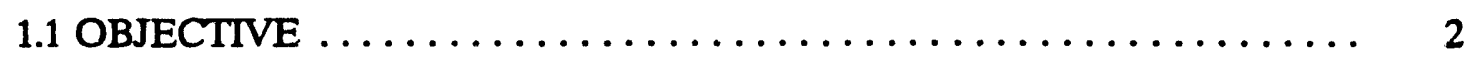

1.2 DEFINITION OF TERMS $\ldots \ldots \ldots \ldots \ldots \ldots \ldots \ldots \ldots \ldots \ldots \ldots \ldots \ldots \ldots$

2. BASE CONSTRUCTION CAPITAL COST GROUND RULES $\ldots \ldots \ldots .99$

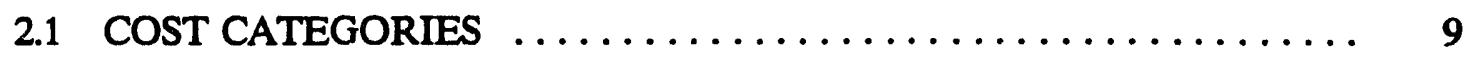

2.2 GENERAL GROUND RULES $\ldots \ldots \ldots \ldots \ldots \ldots \ldots \ldots \ldots \ldots \ldots \ldots$

2.3 SPECIFIC COST-ESTIMATING ASSUMPTIONS ............ 12

2.4 EEDB COST ACCOUNT DEFINITIONS $\ldots \ldots \ldots \ldots \ldots \ldots \ldots \ldots, 23$

2.5 BASE CONSTRUCTION CAPITAL COST DOCUMENTATION ...... 28

2.6 DEVELOPMENT AND PROTOTYPE COST DOCUMENTATION ... 34

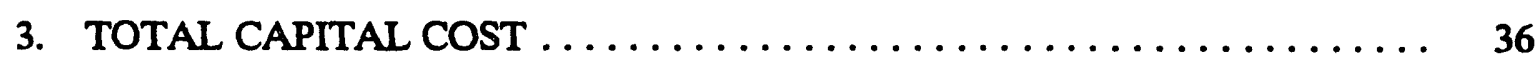

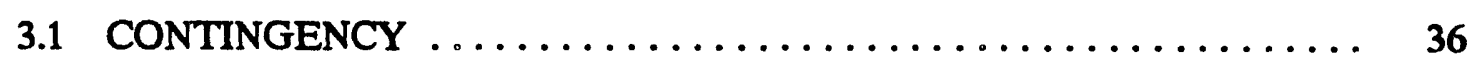

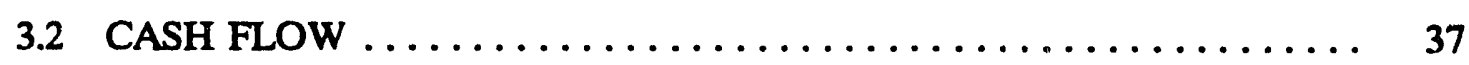

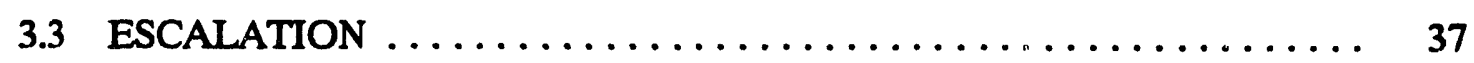

3.4 INTEREST DURING CONSTRUCTION $\ldots \ldots \ldots \ldots \ldots \ldots \ldots \ldots, 38$

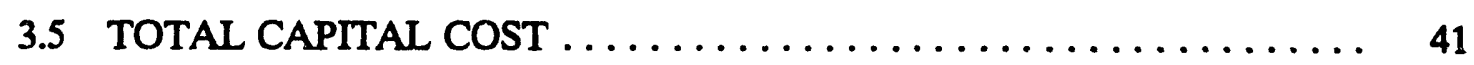

4. BUSBAR GENERATION COST $\ldots \ldots \ldots \ldots \ldots \ldots \ldots \ldots \ldots \ldots \ldots \ldots \ldots \ldots \ldots \ldots$

4.1 GENERAL ASSUMPTIONS AND METHODOLOGY ......... 43

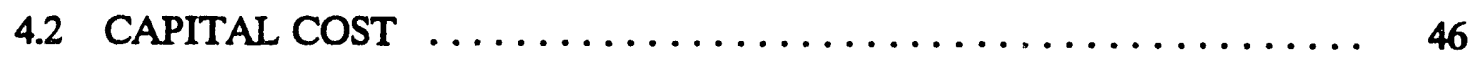

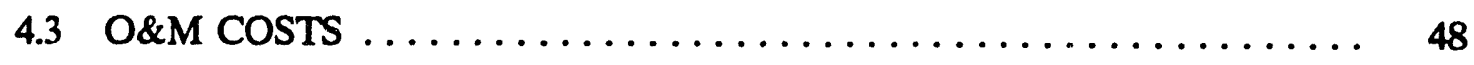

4.4 FUEL COSTS .................................. 54

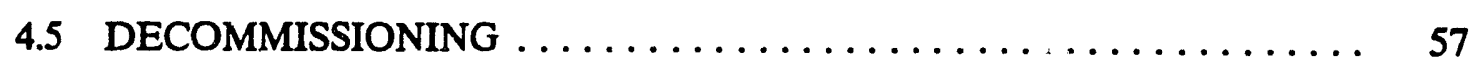

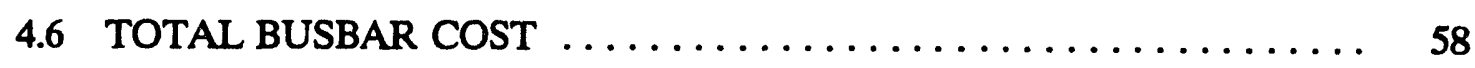

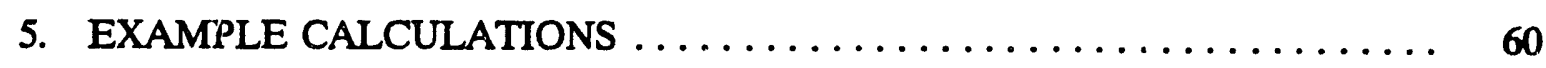

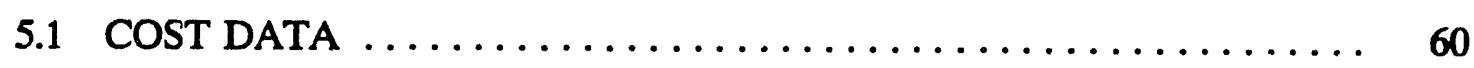

5.2 COST CALCULATION FOR A 600-MWe PULVERIZED COAL (PC) PLANT $\ldots \ldots \ldots \ldots \ldots \ldots \ldots \ldots \ldots \ldots \ldots \ldots \ldots \ldots \ldots \ldots \ldots \ldots, 63$ 
Page

5.3 COST CALCULATION FOR A 500-MWe COMBINED CYCLE COMBUSTION TURBINE PLANT $\ldots \ldots \ldots \ldots \ldots \ldots \ldots \ldots \ldots, 67$

5.4 COST CALCULATION FOR A TWO UNIT 600-MWe PC PLANT ... 71

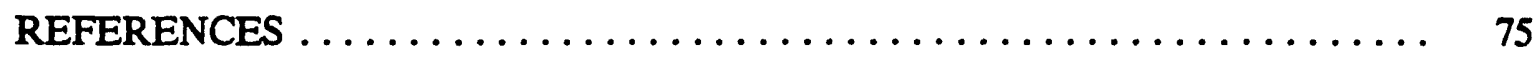

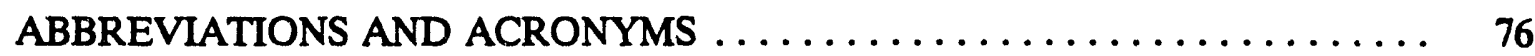

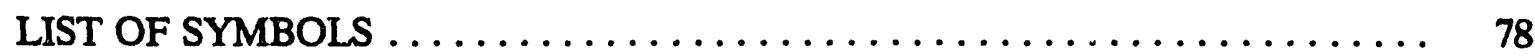

APPENDIX A. EEDB CODE OF ACCOUNTS FOR LIQUID-METAL REACTOR (LMR) CONCEPT $\ldots \ldots \ldots \ldots \ldots \ldots \ldots \ldots, \quad 80$

APPENDIX B. EEDB CODE OF ACCOUNTS FOR HIGH-TEMPERATURE GAS-COOLED REACTOR (HTGR) CONCEPT ......... 105

APPENDIX C. EEDB CODE OF ACCOUNTS FOR AN ADVANCIED LIGHT WATER REACTOR (ALWR) CONCEPT ............ 111

APPENDIX D. LISTING OF SAMPLE FOAK TASKS $\ldots \ldots \ldots \ldots \ldots \ldots \ldots, 133$

APPENDIX E. SITE-RELATED ENGINEERING AND MANAGEMENT

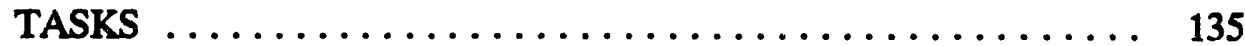

APPENDIX F. EEDB PROGRAM DESCRIPTION OF A STANDARD HYPOTHETICAL EAST/WEST CENTRAL SITE FOR NUCLEAR POWER PLANTS $\ldots \ldots \ldots \ldots \ldots \ldots \ldots \ldots, 136$

APPENDIX G. CONVERSION FROM NOMINAL TO CONSTANT DOLLARS ........................... 142

APPENDIX H. MOST LIKELY, EXPECTED AND CONTINGENCY COSTS ................................. 153 


\title{
COST ESTIMATE GUIDELINES FOR ADVANCED NUCLEAR POWER TECHNOLOGIES
}

\begin{abstract}
To make comparative assessments of competing technologies, consistent ground rules must be applied when developing cost estimates. This document provides a uniform set of assumptions, ground rules, and requirements that can be used in developing cost estimates for advanced nuclear power technologies.
\end{abstract}

\section{INTRODUCTION}

Several advanced power plant concepts are currently under development. These include the Modular High Temperature Gas Cooled Reactors (MHTGR), the Advanced Liquid Metal Reactor (ALMR) and the Advanced Light Water Reactors (ALWR). One measure of the attractiveness of a new concept is its cost. Invariably, the cost of a new type of power plant will be compared with other alternative forms of electrical generation. This report provides a common starting point, whereby the cost estimates for the various power plants to be considered are developed with common assumptions and ground rules. Comparisons can then be made on a consistent basis.

This is the second update of these cost estimate guidelines. ${ }^{1,2}$ Changes have been made to make the guidelines more current (January 1,1992) and in response to suggestions made as a result of the use of the previous report. ${ }^{2}$ The principal changes are that the reference site has been changed from a generic Northeast (Middletown) site to a more central site (EPRI's East/West Central site) and that reference bulk commodity prices and labor productivity rates have been added.

This report is designed to provide a framework for the preparation and reporting of costs. The cost estimates will consist of the overnight construction cost, the total plant capital cost, the operation and maintenance (O\&M) costs, the fuel costs, decommissioning costs and the power production or busbar generation cost. While providing a generic set of assumptions and ground rules, this document does not provide scenarios or assumptions specific to the 
individual concepts, nor does it provide reporting requirements. Thus, these guidelines may be used in a variety of studies when supplemented with concept specific data.

Power plant capital costs in this report will be developed using the U.S. Department of Energy (DOE) Energy Economic Data Base ${ }^{3}$ (EEDB) Program Code of Accounts that has evolved from the NUS Corporation Code of Accounts ${ }^{4}$ through modification and expansion over two decades.

The utilization of the EEDB Code of Accounts will allow for comparisons between the advanced concept cost estimate and costs of other plants reported in the EEDB format. The levelized busbar generation costs will be developed using the methodology presented in the U.S. DOE Nuclear Energy Cost Data Base (NECDB). ${ }^{5}$ All costs will be developed using the methods and tax provisions in the Tax Reform Act of 1986.

These ground rules will be updated as necessary to provide and maintain a common and consistent cost basis. The DOE Office of Nuclear Energy (NE) is responsible for approving changes to this document. Requested changes should be made in writing to Department of Energy Assistant Secretary for Nuclear Energy, Office of Advanced Reactor Pr.ugrams, Washington, D.C. 20545.

\subsection{OBJECTIVE}

Cost estimates for the development, design, construction and operation costs of future power plants involve a great deal of uncertainty. In order to manage the cost estimating task for the advanced nuclear power plant concepts, a number of simplifying assumptions should be made. These include:

- Nuclear plant licensing reform, recently enacted, allows one-step licensing and certification of a standard plant design.

- The Nth-of-a-kind (NOAK) plant is assumed to be built by the same vendor/architectengineer team as the first commercial plant and is identical to the first commercial plant. The plants will be deployed on separate sites.

- An adequate site exists to build a plant (See Appendix F.)

- Adequate project financing is available for all phases of the development, design, construction and operation of the subject plant.

- No provision should be made for acts of God, war, or labor strikes. 
The cost estimate Guidelines are intended to provide a consistent comparison between the advanced reactor technologies. The cost estimates are intended to be reasonable estimates rather than to envelope the ultimate cost in an uncertain environment. The total capital cost estimate should represent the median cost, based on the guideline assumptions where there is an equal probability of the ultimate cost being higher or lower than that cost.

\subsection{DEFINITION OF TERMS}

The following definition of terms will provide the background necessary for understanding and interpreting the present guidelines.

Base construction cost. The base construction cost is the most likely plant capital cost based on the direct and indirect costs only. This cost is lower than the total capital cost because cost elements such as cuntingency, interest, and escalation are NOT included. The specific cost items omitted are listed in Table 1.1.

Table 1.1. Preferential and discretionary items excluded from base construction costs

\begin{tabular}{l}
\hline Allowance for funds used during construction \\
Escalation \\
Contingency (including allowance for \\
indeterminates) \\
Owner's discretionary items \\
Switchyard and transmission costs \\
Generator step-up transformer \\
Initial fuel supply \\
\hline
\end{tabular}

The direct costs are those costs directly associated on an item-by-item basis with the equipment and structures that comprise the complete power plant. The indirect costs are expenses for services applicable to all portions of the physical plant, such as Architect Engineer $(\mathrm{AE})$ home office engineering and design, $\mathrm{AE}$ field office engineering and services, construction management (CM), and taxes. Reactor manufacturer (RM) home office engineering and services are also included in a separate account (see Sect. 2.3, Item 16). 
Building block. A building block is a combination of one or more reactor modules and associated electrical generation equipment and structures that represent the smallest unit for commercial electrical generation. Building blocks may be duplicated for capacity expansion.

Busbar costs. Total levelized power generation costs for electricity produced by a power plant. It includes costs associated with the capital investment, operation and maintenance of the power plant, fuel costs, and the cost of decommissioning the plant at the end of life.

Common plant facilities. Common plant facilities are those systems, structures, and components that are required to support the operation of a first building block at a new plant site and include such facilities as administration building, provisions for refueling, general warehouse, water supply, general fire systems, etc. These common plant facilities may be sized sufficiently so as to be shared by other building blocks added subsequently.

Constant dollars. Constant dollar cost is defined as the cost for an item measured in dollars that have a general purchasing power as of some reference date. As inflation is generally associated with the erosion of the general purchasing power of the dollar, constant dollar analysis factors out inflation.

Construction Module. A construction module is a free standing, transportable preassembly of a portion of the plant. A construction module may be a preassembly of a single system or portion thereof or may contain elements of all the systems that exist in a given location in the plant. A construction module may contain parts of the building structure. A construction module would typically be assembled in a factory, shipped to the plant site and installed in the plant.

Contingency Allowance. The contingency allowance is an adder to the base construction cost to obtain a median cost estimate (see Appendix $\mathrm{H}$ ). Contingency provides an allowance for cost uncertainties. It includes an allowance for indeterminents and should be related to the level of design, degree of technological advance, and the quality/reliability level of given components (see Sect. 3.1). Contingency cost does not include any allowance for potential changes from external factors such as changing government regulations, major design changes, catastrophic events, labor strikes, extreme weather conditions, varying site conditions, or project funding (financial) limitations. 
Escalation rate. The rate of change of a cost. This rate can be greater or less than the general inflation rate as measured by the Gross Domestic Product Implicit Price Deflator.

Equipment. Generally, equipment includes all manufactured items ordered by RM or AE. Such items may be procured on a design and build contract from qualified vendors, wherein design responsibility belongs to the seller (vendor) or is maintained by the buyer (RM or AE) on a "build-to-print" basis. All piping 2-1/2-in. and larger nominal pipe size is an equipment item with the exception of galvanized pipe; storm, roof, and floor drainage; and sanitary piping, which are site material.

Equipment module. An equipment module is a skid-mounted, factory assembled package which includes (but is not limited to) equipment, piping, instrumentation, controls, structural components, and electrical items. Module types include Box Modules, Equipment Modules, Structural Modules, Connection Modules, Electrical Modules, Control System Modules and Dressed Equipment Modules. These Modules are applicable to both the Nuclear Island and Balance of Plant.

Factory (manufacturing facility) FOAK costs. These first of a kind (FOAK) costs include the development of manufacturing specifications, factory equipment, facilities, startup, tooling and setup of factories that are used for manufacturing specific equipment for the concept. These costs may be minimized if existing facilities are used for module production, which might not be dedicated or even its primary use application (e.g. a shipyard or other factory which builds modules for other industries).

First commercial plant costs. The first commercial plant is the first plant of that type that is sold to an entity for the purpose of commercial production of electricity. The costs include all engineering, equipment, construction, testing, tooling, project management, and any other costs that are repetitive in nature. Any costs unique to the first commercial plant which will not be incurred for subsequent plants of the identical design will be identified and broken out separately as FOAK plant costs. The learning for this first plant will reflect its first commercial plant status and not be the average over a larger number of plants.

FOAK plant costs. First-of-a-kind costs necessary to put a first commercial plant in place which will not be reproduced for subsequent plants. Such costs include $R \& D$, standard plant design, NRC certification of standard design and any prototype and other such FOAK costs. 
Force account. Force account involves the direct hiring and supervision of craftsmen to perform a construction activity by a prime contractor as opposed to the prime contractor hiring a subcontractor to perform these functions.

Industrial grade construction. Industrial grade construction means construction practices which conform to generally accepted commercial requirements such as those required for fossil-fired plant construction.

Inflation rate. The rate of change in the general price level as measured by the Gross Domestic Product Implicit Price Deflator.

Large monolithic plant. A large monolithic plant is defined as a power plant consisting of a single, large nuclear steam supply system (NSSS) having a power output at least two and possibly four times as large as a typical modular building block. In some instances, a plant of this size is referred to as an integrated plant.

Materials. Basically, materials include field-purchased (site material) and/or bulk items such as lumber, concrete, structural steel, and plumbing items. Prefabricated pipe is an equipment item. All other piping, less than 2-1/2-in. nominal pipe size, is a materials item with the exception of pipe for cryogenic fluids, which is an equipment item. Also all wire and cable and raceways are material items, including those in building service power systems.

Multi-block plant. A power plant consisting of multiple building blocks is referred to as a multi-block plant.

Nominal dollars. Nominal dollar cost is defined as the cost for an item measured in as-spent dollars and includes inflation. Nominal dollars are sometimes referred to as "current" dollars, "year of expenditure" dollars, or "as spent" dollars in the literature.

Nominal cost of money. The nominal cost of money is the percentage rate used in calculations involving the time value of money containing an inflation component. It explicitly provides for part of the return on an investment to be solely for the purpose of keeping up with inflation.

Nth-of-a-kind (NOAK) plant costs. The NOAK plant is the nth-of-a-kind or equilibrium commercial plant of identical design to the first commercial plant. NOAK plant costs include all engineering, equipment, construction, testing, tooling, project management, and any other costs that are repetitive in nature and would be incurred if an identical plant 
were built. The NOAK plant also reflects the experience of prior plants leading to the NOAK plant (see Sect. 2.3, Item 6).

Nuclear safety grade. Nuclear-safety grade construction means construction practices which satisfy the requirments of 10CFR50, Appendix B.

Prototype facility and test costs. Costs specific to any prototype plant required. These include prototype-specific design, development, lizensing, construction, testing, and operation of the prototype to support the standard plant design certification.

R\&D costs. Costs associated with material, component, system, process and fuel development and testing performed specifically for the particular advanced concept.

Reactor module. A reactor module is a single reactor and that portion of the nuclear island which is duplicated with the addition of each reactor, able to generate thermal heat as an integral part of a building block of power production.

Real cost of money. The real cost of money is the percentage rate used in calculations involving the time value of money when the inflation component has been removed. Calculations using the real cost of money assume that the dollar maintains a constant value in terms of purchasing power, and, thus, no return on an investment is needed for inflation.

Single-block plant. A stand-alone commercial power plant consisting of a single building block and all necessary common plant facilities is referred to as a single-block plant. This is the smallest unit of capacity normally sold to a customer.

Standard plant design costs. Costs associated with the engineering and engineering support functions for the design of the standard plant.

Standard plant NRC curtification costs. Costs associated with licensing related activities performed to establish the design or licensability of the standard plant, including the design and analysis of prototype tests necessary for certification, coordination with NRC and preparation of documents required to obtain NRC certification of the standard plant design.

Standard fuel facility design costs. These costs include the design and engineering of facility and equipment, proof testing of equipment and licensing for any concept. Standard fuel facilities may be either integral to the power plant, central or both.

Technology development costs. See R\&D costs. 
Transition period. The period starting with the first commercial plant and extending to the NOAK plant.

Transition period plant-specific capital costs. The capital costs for the transition plants. These costs exclude any FOAK costs and include costs for manufacturing of factory equipment, site construction, site-specific engineering, and home office construction support. The transition in costs from the first to NOAK commercial plant and the effects of serial manufacturing and construction should be documented.

Total capital cost. The total capital cost is an all inclusive plant capital cost developed for the purpose of calculating the plant busbar electricity cost. This cost is the base construction cost plus contingency, escalation, and interest-related costs.

Total overnight cost. The total overnight cost is the base construction cost plus applicable contingency costs. It is referred to as an overnight cost in the sense that time value costs (interest during construction and escalation) are not included. Total overnight cost is expressed as a constant dollar amount in reference year dollars. 


\section{BASE CONSTRUCTION CAPITAL COST GROUND RULES}

\subsection{COST CATEGORIES}

The estimated costs will be reported in eight independent categories as defined in Sect. 1. These are:

1. Technology Development (R\&D) costs

2. Standard plant design costs

3. Prototype facility and test costs

4. Standard plant NRC certification costs

5. Standard fuel facility R\&D, design, test and certification costs

6. Factory FOAK costs

7. First commercial plant costs

8. NOAK plant costs

If desired, the costs for plants in the transition from the first commercial to the NOAK plant can be given also. In any event, the transition in costs from the first commercial to NOAK commercial plant and the effects of serial manufacturing and construction should be documented.

Costs are to be expressed in constant reference year dollars. All Technology Development (R\&D), standard plant design, and NRC certification, prototype and other onetime costs necessary before the first commercial plant can be built, and any one-time costs for the first commercial plant are included in categories 1-6. All categories may not be applicable for a given concept (e.g. a prototype plant may not be needed for all advanced concepts). A sample listing of these first plant tasks is given in Appendix D. All costs in categories $1-6$ should be reported in only one category and should not be amortized into the first commercial or subsequent plants except as reflected in site-delivered equipment costs from a dedicated factory (see Sect. 2.2, Item 8). The timing of all expenditures should be identified. Fuel cycle facility construction and operating costs are discussed in Sect. 4.4.

The specification of the costs into categories $1-7$ and their time distributions allows these estimates to be combined as appropriate and allows the total expenditures for a concept up through the first commercial plant to be shown as a function of time. If the transition plant costs and NOAK plant costs are included, the costs and time distributions may be 
combined as appropriate for a given plan of commercialization and allows the total expenditures for a concept to be shown as a function of time.

Distributions of costs in each category are to be presented in a way which is consistent with the way they were estimated. Power plant capital costs must be given in the EEDB format.

All values in the eight categories are defined as costs to the buyer and include supplier profit margins. Representative margins (markup) of $15 \%$ for NSSS equipment suppliers and $7 \%$ for BOP suppliers are to be used. Vendor prices are to be based on quotations or margins consistent with the economic parameters for industrial organizations given later in the guidelines.

\subsection{GENERAL GROUND RULES}

This section describes the ground rules to be followed in developing the base construction capital cost for the advanced concepts.

1. The EEDB Code of Accounts will be the structure used for cost estimates and cost accumulation. The EEDB Code of Accounts is an evolutionary expansion and modification of the NUS 531 Code of Accounts. Sample EEDB Code of Accounts for the advanced liquid metal reactor (ALMR), the modular high-temperature gas-cooled reactor (MHTGR), and a light water reactor are given in Appendices A, B, and C, respectively.

2. Detailed cost estimates will be reported in constant January 1 dollars for the year specified by DOE-NE. Current studies should be reported in constant January 1, 1992 dollars.

3. The cost estimates will reflect the plant requirements and design as detailed in the Design Requirements, System Design Descriptions (SDDs), and other formal design documentation. Individual system boundaries will be as defined in the SDDs.

4. The base construction cost estimates will be developed so that they are the most likely cost for a particular EEDB cost entry without any allowance for funds used during construction (AFUDC) (interest), escalation, or contingency allowance as defined in

Sect. 3. The cost estimates shall be based on quantities of commodities/materials and 
equipment together with unit costs (see Table 2.2). The installation costs shall be based on quantitites, installation rates (see Table 2.3) and labor rates (see Table 2.1).

5. Assumed use of any government-owned or -operated facility shall be costed at full cost recovery, including all direct costs, related indirect costs, depreciation, and any other related general and administrative costs. Inquiries regarding prices and charges to be assumed for specific materials and services shall be made to the Office of Advanced Reactor Programs, DOE-NE.

6. All construction and installation costs may reflect a separated construction concept whereby nuclear-safety grade and Seismic Category 1 construction are separated from conventional industrial (nonnuclear-safety) construction. All costs of equipment, materials, storage, quality assurance $(\mathrm{Q} / \mathrm{A})$, quality control $(\mathrm{Q} / \mathrm{C})$, and labor productivity for the non-nuclear safety areas will reflect conventional industrial practice. The portions or fractions of the plant constructed under each construction grade shall be documented.

7. As an aid in establishing system-to-system boundaries for costing purposes, the following general guidelines are set forth:

a. The cost estimate for a system, equipment, facility, or structure shall include those costs associated with fabricating, installing, and/or constructing the particular item described in the SDDs or Building and Structures Design Descriptions (BSDDs).

b. For costing purposes, the boundaries of a system, facility, or structure are as defined in the SDDs or BSDDs and in the piping and instrumentation diagrams (P\&IDs).

c. The cost for all electrical power terminations, including connectors, shall be borne by the electrical power system. For the trace heating system, the interface with the electrical power system is the individual heater controllers. For building service power and lighting systems, the interface with the electrical power system is the individual power lighting panel.

d. The expense for terminating instrumentation and control cabling and wiring with the exception of control system fiber optic cabling shall also be included in the electrical power system. This includes terminations with individual sensors as well as providing electrical interconnections between panels, cabinets, consoles, data processing units, controllers, etc. The expense for terminating the control system fiber optics shall be included with the control system. 
e. Costs for routing and laying or pulling wire and cable in ducts, conduits, and trays shall be included in the electrical power system.

f. The costs for attachments to structures (e.g., anchor bolts and auxiliary steel) shall be borne by the equipment item requiring the support. Embedments are included in the costs of structures.

8. If the NOAK plant utilizes a dedicated factory for producing construction modules for the NSSS and/or balance of plant (BOP), the amortization of the factory cost over the production life must be included in the NOAK plant cost. The bases for site-delivered cost assumptions should be reported and should include factory construction cash flow, capitalization and amortization assumptions (e.g., number of units assumed for factory capital cost recovery).

\section{SPECIFIC COST-ESTIMATING ASSUMPTIONS}

The following assumptions will be used in developing the base construction cost estimates.

1. Assumptions on the organizational structure to be used in developing the cost estimate are as follows:

a. Overall project management will be provided by a utility or other entity engaged in the direct production of commercial electricity.

b. A single RM and a single AE contractor will be employed to design NSSS and other plant equipment, to design plant buildings and structures, to prepare all technical documentation and reports, and to support construction activities.

c. A single construction manager (CM), which may also be the $\mathrm{AE}$ contractor, will be responsible for construction activities.

d. These assumptions do not exclude a single vendor/supplier entity that would supply and construct commercial facilities.

2. The following assumptions apply to costing the first commercial plant:

a. The costs for this plant should not include any of the costs included in category 1-6 given in Sect. 2.1 except as reflected in site-delivered equipment costs from a dedicated factory. If there are exceptions to this, these are to be clearly identified. 
b. Any learning included in the costing of the plant should reflect that the plant is a first plant. An average learning or cost for a series of plants is not acceptable for the first commercial plant cost estimate.

c. The cost estimate will include the cost for all site-specific licensing or prelicensed sites. A generic plant design approval should be assumed.

d. Plant costs include all engineering, equipment, construction, testing, tooling, project management costs, and any other costs that are repetitive in nature and would be incurred in building an identical plant. A sample listing of repetitive engineering and management tasks is presented in Appendix $\mathrm{E}$.

3. The following assumptions apply to costing the NOAK plant:

a. Design is identical to the first commercial plant.

b. The plant site is enveloped by the reference site conditions.

c. No product improvements are incorporated; that is, the first commercial plant design is frozen.

d. Equipment manufacture and plant construction are performed by the same contractors as for the first plant.

e. There are no changes in NRC regulations or major codes andi standards subsequent to the first plant time frame.

f. The cost estimate will include the cost for all site-specific licensing or prelicensed sites. A generic plant design approval should be assumed.

g. Plant costs include all engineering, equipment, construction, testing, tooling, project management costs, and any other costs that are repetitive in nature and would be incurred in building an identical plant. A sample listing of repetitive engineering and management tasks is presented in Appendix E.

4. Labor rates for craftsmen employed to assemble equipment at any on-site fabrication shop will be the same as construction crew rates.

5. All plant construction will be accomplished by force account with exception of those tasks subcontracted by the AE. Costs for all tasks, including subcontracted tasks, must be reported as equipment cost, material cost, and labor hours and cost.

6. Reductions in factory equipment costs due to learning effects may be recognized. Unless a different value is substantiated and documented, the estimator shall use a $94 \%$ unit 
learning curve (percentage for each item doubling) for estimating individual factory equipment items. The $94 \%$ unit learning curve is a composite curve and includes both labor learning and material cost discounts (see item 18). For costing equipment items for the NOAK plant, all concepts must assume that the NOAK plant is that unit whose manufacturing first places the cumulative net production of that type of plant at or in excess of $4500 \mathrm{MW}(\mathrm{e})$. The base or starting point for cost reduction due to learning will be equipment items for the first unit of equipment manufactured for the first commercial power plant. The cost for a given equipment item for the NOAK plant should reflect the cumulative production history for that item as determined by the cumulative item requirements necessary to satisfy the NOAK unit definition above. The learning curve reductiol. shall apply only to items which are not commercially available, off-the-shelf items. Unless a different value is substantiated and documented, the estimator shall use $\mathbf{9 7 \%}$ learning curve for field labor on the same site and $98 \%$ from site to site.

7. It will be assumed for the estimates that all engineering information, including specifications and drawings, will be released for construction in time for efficient planning and performance of the work and further that all equipment, material, and labor resources are available as required.

8. It will be assumed that the baseline construction requires no premium time (overtime) work to recover from schedule delays. Costs for possible schedule recovery overtime will. be reflected in the contingency cost (see Sect. 3.1). The use of premium time for normal baseline construction over and above a $40-\mathrm{h}$ week should be identified.

9. It will be assumed that funding is available as required to support uninterrupted design, testing, construction, installation, checkout, and plant startup.

10. The industrial non-nuclear-safety portion of each plant is designed and erected to the same standards as a conventional fossil-fuel power plant. Only the nuclear-safety-grade structures and equipment require the more elaborate procedures, documentation, and $\mathrm{Q} / \mathrm{A}-\mathrm{Q} / \mathrm{C}$ overview. Any on-site fuel manufacturing, handling, and reprocessing facilities will be assumed to be nuclear-safety-grade.

11. Site conditions for each plant are similar to those at a hypothetical East/West Central site as described in Appendix F: 
a. An adequate pool of qualified craft labor is available.

b. There are no unique nuclear or conventional licensing restrictions that would affect plant design, construction, or operation.

c. Estimates cover work within the plant security fence and include the water intake systems and structures.

d. Soil and subsurface conditions are such that no unusual problems are associated with soil-bearing capacity or rock removal, major cut and fill operations, and dewatering.

12. Site land (Account 20) shall be based on the estimated site area, including any buffer zones (500 acre minimum) and a cost of $\$ 10,000$ /acre. It is to be assumed that the total land cost is incurred at the same time as the decision is made to build a plant.

13. Cost items to be excluded from the base construction cost estimate were listed in Table 1.1.

14. The assumptions to be used for the estimates of the Engineering and Home Office Services for all plants are defined in Appendices D and E.

15. Engineering and Home Office Services includes the AE costs for design, engineering, procurement, cost engineering, $Q / A-Q / C$, reproduction services, etc. (Account 92). Any module fabricator costs for engineering, Q/A etc should be separately shown.

16. Nonrecurring engineering and home office services costs of the RM are assumed to be zero for the first commercial and NOAK plant. Any applicable recurring RM engineering costs should be identified.

17. Composite wage rates (base rate plus fringes) to be used for the site in 1992 dollars are given in Table 2.1 and the cost of major materials is given in Table 2.2.

18. There should be no reduction in field material prices based on quantity discounts. For factory produced modules, an equipment learning curve of $94 \%$ was specified (see item 6). The $94 \%$ factor includes provision for volume discounts on materials. If labor and material learning is estimated separately, the material price discounts for high volume items should be limited to $10 \%$ for NOAK plants. There should be no such discounts for first commercial plants. 
16

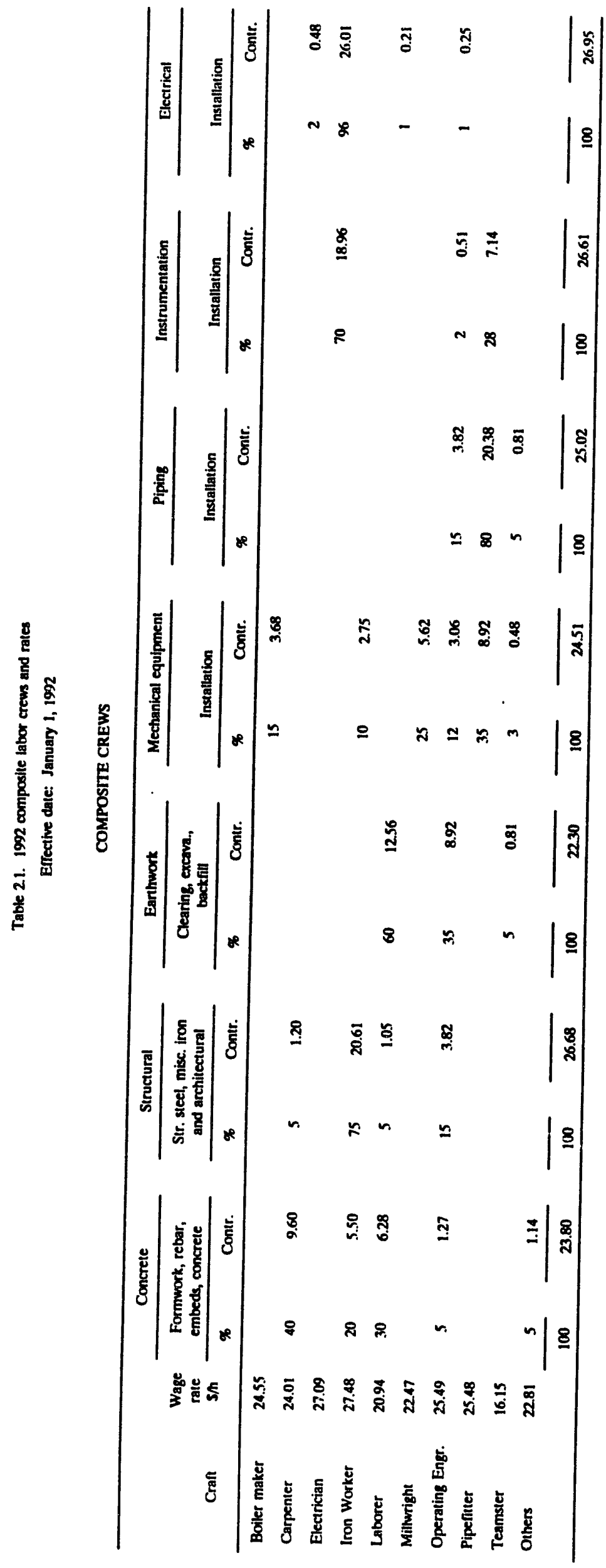


Table 2.2. Cost of Major Materials - Bulk

Effective Date: January 1, 1992

\begin{tabular}{|c|c|c|c|}
\hline Commodity & $\begin{array}{l}\text { Unit of } \\
\text { measure }\end{array}$ & $\begin{array}{c}\text { Nuclear } \\
\mathbf{S}\end{array}$ & $\begin{array}{c}\text { Non-nuclear } \\
\mathbf{S}\end{array}$ \\
\hline \multicolumn{4}{|l|}{ STRUCTURAL COMMODITIES } \\
\hline Formwork & SF & 2.00 & 1.85 \\
\hline Decking & SF & 5.00 & 3.00 \\
\hline Reinforcing steel & TN & 700.00 & 450.00 \\
\hline Embedded metal & LB & 2.50 & 1.50 \\
\hline Concrete & CY & 90.00 & 60.00 \\
\hline Structural steel & TN & $3,100.00$ & $1,400.00$ \\
\hline Miscellaneous steel & TN & $6,000.00$ & $3,000.00$ \\
\hline \multicolumn{4}{|l|}{ PIPING COMMODITIES } \\
\hline 2 in. and under screwed pipe & LF & 26.00 & 21.00 \\
\hline 2 in and under CS welded pipe & LF & 36.00 & 26.00 \\
\hline 2 in. and under $C M$ welded pipe & LF & 50.00 & 38.00 \\
\hline 2 in. and under SS welded pipe & LF & 50.00 & 38.00 \\
\hline 4 in. CS sch 40 (0.237 in.) spooled pipe & LF & 88.00 & 38.00 \\
\hline 4 in..$M$ sch $40(0.237$ in.) spooled pipe & LF & 175.00 & 100.00 \\
\hline 4 in. SS sch 40 (0.237 in.) spooled pipe & LF & 210.00 & 125.00 \\
\hline 12 in. CS sch 80 (0.688 in.) spooled pipe & LF & 400.00 & 360.00 \\
\hline 12 in. $C M$ sch 80 (0.688 in.) spooled pipe & LF & 810.00 & 750.00 \\
\hline 12 in. SS sch 80 (0.688 in.) spooled pipe & LF & $1,260.00$ & $1,210.00$ \\
\hline 20 in. CS sch 120 (1.50 in.) spooled pipe & LF & $1,100.00$ & $1,040.00$ \\
\hline \multicolumn{4}{|l|}{ ELECTRICAL COMMODITIES } \\
\hline 2 in. dia. rigid steel exposed conduit & LF & 7.50 & 5.00 \\
\hline 4 in. dia. non-metallic duct bank conduit & LF & 3.60 & 2.90 \\
\hline 24 in. $\times 3$ in. aluminum cable tray & LF & 16.20 & 10.80 \\
\hline $\begin{array}{l}600 \text { volt power and control cable } \\
\text { (Avg. } 5 \mathrm{C}, \# 12 \text { ) }\end{array}$ & LF & 2.10 & 1.70 \\
\hline $\begin{array}{l}600 \text { volt instrumentation cable } \\
\text { (Avg. } 2 \mathrm{Pr} \text {., Shld, \#18) }\end{array}$ & LF & 1.10 & 0.90 \\
\hline $\begin{array}{l}\text { 5-15 kV power cable } \\
\text { (Avg. } 3 \mathrm{C}, \# 250 \text { ) }\end{array}$ & LF & 5.50 & 4.40 \\
\hline 600 volt connections & EA & 2.00 & 1.00 \\
\hline 5-15 kV connections & EA & 95.00 & 65.00 \\
\hline
\end{tabular}


Table 2.3. Bulk Commodity Unit Hour Installation Rates (man hours/unit)

\begin{tabular}{|c|c|c|c|}
\hline Commodity & $\begin{array}{c}\text { Unit of } \\
\text { measure }\end{array}$ & Nuclear & Non-nuclear \\
\hline \multicolumn{4}{|l|}{ STRUCTURAL COMMODITIES } \\
\hline Formwork - substructure & SF & 0.64 & 0.48 \\
\hline Formwork - superstructure & SF & 1.12 & 0.84 \\
\hline Decking & SF & 0.16 & 0.12 \\
\hline Reinforcing steel - substructure & TN & 32.00 & 24.00 \\
\hline Reinforcing steel - superstructure & TN & 40.00 & 30.00 \\
\hline Embedded metal & LB & 0.11 & 0.08 \\
\hline Concrete - substructure & $\mathrm{CY}$ & 2.00 & 1.50 \\
\hline Concrete - superstructure & $\mathrm{CY}$ & 4.00 & 3.00 \\
\hline Structural steel & TN & 64.00 & 14.40 \\
\hline Miscellaneous steel & TN & 120.00 & 72.00 \\
\hline \multicolumn{4}{|l|}{ PIPING COMMODITIES } \\
\hline 2 in. and under screwed pipe & LF & 3.46 & 1.30 \\
\hline 2 in. and under CS welded pipe & LF & 5.18 & 1.94 \\
\hline 2 in. and under $C M$ welded pipe & LF & 8.06 & 3.02 \\
\hline 2 in. and under SS welded pipe & LF & 10.37 & 3.89 \\
\hline 4 in. CS sch 40 (0.237 in.) spooled pipe & $\mathbf{L F}$ & 5.70 & 2.14 \\
\hline 4 in. $C M$ sch 40 (0.237 in.) spooled pipe & LF & 13.71 & 5.14 \\
\hline 4 in. SS sch 40 (0.237 in.) spooled pipe & LF & 11.40 & 4.28 \\
\hline 12 in. CS sch 80 (0.688 in.) spooled pipe & LF & 13.41 & 5.03 \\
\hline 12 in. $C M$ sch 80 (0.688 in.) spooled pipe & LF & 29.02 & 10.88 \\
\hline 12 in. SS sch 80 (0.688 in.) spooled pipe & LF & 26.82 & 10.06 \\
\hline 20 in. CS sch 120 (1.50 in.) spooled pipe & LF & 42.62 & 15.98 \\
\hline \multicolumn{4}{|l|}{ ELECTRICAL COMMODITIES } \\
\hline 2 in. dia. rigid steel exposed conduit & LF & 1.26 & 0.58 \\
\hline 4 in. dia. non-metallic duct bank conduit & LF & 0.35 & 0.16 \\
\hline 24 in. $\times 3$ in. aluminum cable tray & LF & 2.88 & 1.32 \\
\hline 600 volt power and control cable & LF & 0.13 & 0.06 \\
\hline
\end{tabular}


Table 23. (continued)

\begin{tabular}{llcr}
\hline \multicolumn{1}{c}{ Commodity } & $\begin{array}{c}\text { Unit of } \\
\text { measure }\end{array}$ & Nuclear & Non-nuclear \\
\hline 600 volt instrumentation cable & LF & 0.11 & 0.05 \\
$5-15 \mathrm{kV}$ power cable & LF & 0.54 & 0.25 \\
600 volt connections & EA & 0.88 & 0.41 \\
5-15 kV connections & EA & 20.80 & 9.40 \\
& & & \\
INSTRUMENTATION & & & \\
Control panel & LF & 96.00 & 36.00 \\
Field-mounted instrument & EA & 12.80 & 4.80 \\
Instrument tube & LF & 0.96 & 0.72 \\
\hline
\end{tabular}


Table 2.4. Commodity definitions

\begin{tabular}{ll}
\hline \multicolumn{1}{c}{ Description } & \multicolumn{1}{c}{ Commodity content } \\
\hline FORMWORK & $\begin{array}{l}\text { Supply, preparation, assembly, installation, removal and disposal of forming } \\
\text { material. Commodity starting point assumes that forms are wooden and } \\
\text { reused. }\end{array}$ \\
DECKING & $\begin{array}{l}\text { Supply, preparation, and installation of metal decking used to form } \\
\text { concrete slabs. Decking is assumed to be galvanized steel, and remains in } \\
\text { place after concrete is set. Area take-off is exact, and material cost } \\
\text { includes overlap, and waste, corrugated filler, spotwelding, and other } \\
\text { installation aids as needed. }\end{array}$
\end{tabular}

REINFORCING STEEL

EMBEDDED METAL

CONCRETE

STRUCTURAL STEEL

MISCELLANEOUS STEEL

PIPING COMMODITIES

ELECTRICAL CONDUIT

CABLE TRAY

ELECTRICAL AND INSTRUMENT CABLE
Supply of straight bars or vendor-bent bars of reinforcing steel, including necessary materials for supports and field joints. Weight take-off or estimate is for rebar only. Material cost includes supports, joints and related additional material.

Supply, preparation and installation of embedments, including nelson studs or other weldments as needed.

Supply, delivery and placement within the site of mixed structural concrete, with nominal 3000 psi compressive strength. Assumed mixed in a dedicated on-site batch plant. Values include heat control or ice addition, patch and sack, curing mixes, hardeners, expansion and construction or seismic joint materials, if needed.

Supply, preparation, installation, alignment, and bolting or welding of prefabricated painted steel shapes and structures. Includes column base plates, grouting, touch-up painting, etc.

Supply, preparation, installation, alignment, and bolting or welding of prefabricated painted steel shapes, structures, and components. This commodity includes stairs, platforms, hand railings, toe plate, door and opening frames, grating, checker plate, etc.

Piping commodities include pipe, fittings, hangers and supports, installation, alignment and tack-welding (when appropriate), welding, and post-weld heat treatment if necessary. Installation includes non-destructive esting, flushing, and hydrotesting. Piping excludes the material cost of valves, but includes the installation labor for valves. Separate commodities are used for insulation, vacuum jacketing, heat tracing, and painting. Piping 2 in. and smaller is predominantly supplied as straight run material and field fabricated or on-site pre-fabricated. Larger piping is predominantly shop prefabricated and supplied to the tield as spoolpieces. Only joints needed to allow shipping and installation are installed in the tield.

Supply and installation of electrical conduit, including hinges, supports, attachments, fittings including installation devices such as pull boxes.

Supply and installation of electrical cable tray, including hangers, supports, connecting pieces, barriers, covers, etc.

Supply and installation of electrical conductors, including tray ties and other installation aids. Excludes conduit, tray, and terminations. Electrical terminations include cable end preparation and supply and installation of connectors, lugs, boots, taps, ferrules, clamps, etc. 
19. Bulk commodity unit hour installation rates are given in Table 2.3 for nuclear and non-nuclear construction practices. Bulk commodity definitions are given in Table 2.4. The data in Tables 2.2-2.4 were obtained from actual architect/engineer cost experience. ${ }^{6}$ Material $\mathbf{u}^{-}:$: rates were obtained from an aggregate of current commodity vendor data. Labor installation rates were developed by applying a productivity factor to estimating standard rates. Nuclear productivity factors were developed from a set of early nuclear projects, which did not undergo the upset and turmoil of the post-TMI backfitting experience. Non-nuclear installation rates were developed from current fossil power project experience. While these data values may not be the absolute best that can bi: achieved under the licensing and construction environment described by thesie groundrules, they represent a data set sufficient for the preparation of consistent conceptual cost estimates. The bulk commodity unit costs (Table 2.2) and installation rates (Table 2.3) do not comprise the complete set of such information needed to cost a plant design. Any exception to the labor rates, commodity prives and installation manhours shown on Tables 2.1, 2.2, and 2.3 shall be justified.

20. Crpital costs shall be separated into two categories related to whether the equipment/construction is nuclear-safety-grade or industrial non-nuclear-safety-grade. The plant design contractor (RM's and AE's) shall determine the boundaries of the nuclear-safety-grade and industrial non-nuclear-safety grade areas. Costs within each category will be reported in EEDB format as illustrated in Appendices A, B, and C.

21. Although included and reported in the overall plant estimate, costs of common plant facilities will, in addition, be identified at the two digit account level and listed separately in EEDB format as discussed above.

22. In cases where equipment items or piping are combined with structural members to produce a factor $y$-assembled equipment module, a work sheet documenting each module should be prepared. The work sher: will identify by three-digit EEDB account the applicable items and costs that comprise the module. For each three-digit account, the work sheet will provide the equipment and material costs, shop and field labor hours and costs, factory overhead and profit, freight, and total module cost. In addition, the text must describe the approach used to estimate each of the cost items. In regard to the total plant cost estimate, three-digit level costs for items that are part of a factory 
module must remain in the EEDB account that represents that particular item i.e., costs for structural portions of a module should be ieported in Account 21 and equipment/ piping costs should be reported in the relevant system account (Accounts 22-26). ${ }^{3}$ The total factory cost, including shop labor and materials, should be recorded as factory equipment costs in the EEDB cost estimate format. Field labor to install a module should be recorded as site labor in the EEDB estimate format. Labor costs to produce and/or install a module may be prorated among the related three-digit EEDB accounts, if necessary. The basis for cost-related assumptions regarding the module factory must be documented. Such assumptions include factory location, factory labor rates, labor unit productivity, factory overhead, and module shipping cost assumptions. The wage rates for factory craft workers should be based on the field craft labor data for the factory site. Any adjustments to the labor rates to reflect the factory environment must be fully supported in the cost estimate report.

23. For large equipment items and modules, the site delivered traniportation costs are to be identified as a line item.

24. For large factory equipment items such as the reactor vessel and internals, steam generators, heat exchangers, etc., supporting cost data by component must be available for review. The supporting data will include factory material cost, material weights, factory man-hours, recurring cost, and total cost for each equipment item.

25. The heat rejection system will be designed for the site conditions as described in Appendix F such that the turbine exhaust pressure will be at or below the design value $01 \%$ of the time.

26. The estimator will use cost information relevant to the reference date (January 1, 1992 for current studies) where pcssible. If such information is not available, costs in terms of another reference year may be adjusted, where applicable, using appropriate cost indices. Examples of such adjustment factors using both the Gross Domestic Product Implicit price deflator ${ }^{7}$ and the Handy-Whitman cost index ${ }^{8}$ for Nuclear Production Plant Electric Utility construction costs (North Central region) are given in Table 2.5. 
Table 2.5. Escalation adjustment factors

\begin{tabular}{cccccccc}
\hline & & \multicolumn{5}{c}{ Nuclear plant cost adjustment factors } \\
\cline { 3 - 7 } & $\begin{array}{c}\text { Implicit } \\
\text { price }\end{array}$ & \multicolumn{5}{c}{ EEDB account number } \\
\cline { 3 - 7 } Initial & $\begin{array}{c}\text { priction } \\
\text { year }\end{array}$ & 21 & 22 & 23 & 24 & 25 & Total \\
\hline 1987 & 1.203 & 1.120 & 1.197 & 1.162 & 1.277 & 1.167 & 1.178 \\
1988 & 1.165 & 1.072 & 1.108 & 1.106 & 1.242 & 1.119 & 1.111 \\
1989 & 1.118 & 1.050 & 2.072 & 1.056 & 1.073 & 1.074 & 1.066 \\
1990 & 1.073 & 1.020 & 1.031 & 1.067 & 1.059 & 1.039 & 1.028 \\
1991 & 1.030 & 1.004 & 1.014 & 1.010 & 1.022 & 1.013 & 1.010 \\
1992 & 1.0 & 1.0 & 1.0 & 1.0 & 1.0 & 1.0 & 1.0 \\
\hline
\end{tabular}

- Cost escalation factors from initial year to January 1, 1992.

'January 1 of dates shown.

Increase from 4th quarter of previous year until 4th quarter of 1991, Source: Ref. 7.

Source: Ref. 8. Nuclear Production plant Electric Utility construction cost index for North Central region.

\section{EEDB COST ACCOUNT DEFINITIONS}

\subsection{Direct Cost Accounts}

Direct costs include those construction and installation costs directly associated with the operating plant structures, systems, and components. At the two digit level of detais, the direct cost accounts include: land and land rights (20), structures and improvements (21), reactor plant equipment (22), turbine plant equipment (23), electric plant equipment (24), miscellaneous plant equipment (25), and the main condenser heat reject system (26). Each account is divided into equipment, site labor and site material costs as described below.

\subsubsection{Equipment Costs}

Equipment costs include the costs for all design, analysis, fabrication, documentation preparation, predelivery testing, and follow-up engineering performed by equipment vendors; materials for all plant equipment; equipment; transportation and insurance expenses; provision of shipping fixtures and skids; warranties; preparation of maintenance and operations manuals and handling instructions; delivery of startup and acceptance test equipment; on-site unloading and receiving inspection expenses; and overhead expenses. 
All plant equipment items, whether directly associated with the power generation systems or the facility systems, such as heating and ventilation, are included in this category.

For the equipment fabricated and/or assembled at an on-site fabrication facility, all the associated costs are included as equipment costs, including the fabrication and/or assembly costs and the costs to move the equipment within the facility to its on-site receiving or storage point. The on-site labor related to installation of shop fabricated modules should be included in the field labor and not as factory equipment. Field labor rates should be used for any onsite fabrication facility.

\subsubsection{Site Labor Cost}

The site labor portion of the construction and equipment installation costs includes all on-site activities related to permanent plant structures, systems, and equipment required for all aspects of power plant operation.

The direct costs of all work crews and foremen to excavate, backfill, erect, and finish structures and to place and install equipment, piping, wiring, modules, etc. are included.

Labor rates for this work include base rates, fringe benefits, and any travel or subsistence allowances.

All direct construction and installation costs are on a force account basis (see Sect. 1.2).

For this estimate, the costs associated with installing equipment items for both NSSS and BOP systems include the labor to transport the equipment from on-site storage or the on-site fabrication facility to the final resting place as well as the labor to align the equipment, physically attach it to the supporting structure and test it. In addition, the labor costs for providing mechanical hookups and electrical connections between interfacing systems will be included.

\subsubsection{Site Materials Cost}

Site materials include all materials purchased in the field and/or bulk items such as paint, concrete, rebar, welding rod, formwork, etc. All piping, less than 2-1/2-in. nominal pipe size, is a materials item with the exception of pipe for cryogenic fluids. Also all wire, cable, and raceways except the control system fiber optic cabling are material items, including those in building service power systems. The control system fiber optic cabling shall be included with the control system equipment. 


\section{Indirect Cost Accounts}

The indirect cost accounts include those construction support activities required to design and build the structures and systems described in the direct cost accounts. At the twodigit account level of detail, the indirect cost accounts collect the costs for construction services, home office engineering and services, field office engineering and services and owner's cost. A bottoms up estimate for indirect costs is recommended. The cost estimate procedure should be fully documented by the estimator.

The following subsections provide a description of the indirect costs by three-digit EEDB accounts.

\subsection{Construction Services Costs (Account 91)}

Construction services (Account 91) includes costs for CM-related activities associated with construction as indicated below:

Temporary construction facilities (Account 911). This subaccount includes temporary structures and facilities, janitorial services, maintenance of temporary facilities, guards and security, roads, parking lots, laydown areas, and temporary electrical, heat, air, steam and water systems, general cleanup, etc.

Construction tools and equipment (Account 912). Construction tools and equipment include rental and/or purchase of construction equipment, small tools and consumables (fuel, lubricants, etc.), as well as maintenance of construction equipment.

Payroll insurance and taxes (Account 913). These expenses include insurance and taxes related to craft labor (direct and indirect including guards and janitors), such as social security taxes and state unemployment taxes, workmen's compensation insurance, and public liability and property damage insurance.

Permits, insurance and local taxes (Account 914). Consistent with other EEDB-type estimates, builders all-risk insurance will be the only cost included in Account 914. Payments to federal, state, and local governments for taxes, fees, and permits are to be included in Account 942 because they are plant specific.

\subsection{Engineering and Home Office Services Costs (Account 92)}

Engineering and home office services are site specific and include all AE management, engineering design, licensing and associated support activities. The costs for these services 
include salaries, direct payroll-related costs (DPC), overhead loading expenses, and fees for these services. This cost element includes activities as given below.

Reactor Module Engineering and Services (Account 920). These costs include site specific reactor module engineering and licensing (both field and home office), procurement and expediting activities, estimating and cost control, engineering planning and scheduling, reproduction services, and expenses associated with the above functions. These costs may be included in the cost of the NSSS package but should be broken out separately.

AE Engineering and home office expenses (Account 921). These costs include AE engineering and design (both field and home office), procurement and expediting activities, estimating and cost control, engineering planning and scheduling, reproduction services, and expenses associated with performance of the above functions (i.e., telephone, postage, computer use, travel, etc.).

AE Home office quality assurance (Account 922). This account includes the services of home office QA engineers and staff personnel engaged in work on the project. Services include reviews, audits, vendor surveillance, etc. as required for design and construction of the nuclear safety-related portion of the facility.

AE Home office project management (Account 923). These services include those of the construction manager and his assistants. Services of construction planning and scheduling, construction methods, labor relations, safety, and security personnel are utilized as required.

\subsubsection{Field Supervision and Field Office Services Costs (Account 93)}

Field Supervision and Field Office Services (Account 93) includes costs for CMrelated activities associated with on-site management of construction, site $Q / A$, startup and test, and the supporting costs for these functions as indicated below. Costs of these services include salaries, DPC, overhead loading, relocation costs of key personnel, and fees.

Field office expenses (Account 931). These expenses include costs associated with purchase and/or rental of furniture and equipment (including reproduction), communication charges, postage, stationery, other office supplies, first aid, and medical expenses.

Field job supervision (Account 932). This management function includes the resident construction superintendent and his assistants; craft labor supervisors; field accounting, 
payroll, and administrative personnel; field construction schedulers; field purchasing personnel; warehousemen; survey parties; stenographers; and clerical personnel.

Field OAVC (Account 933). These services include those of personnel located at the job site engaged in equipment inspection, required documentation of safety-related equipment, inspection of construction activities, and construction training meetings.

Plant startup and test (Account 934). These services are associated with preparation of startup and plant operation manuals and test procedures, direction and supervision of testing of equipment and systems as the plant nears completion, and direction of startup of the facility. Costs of any craft labor required for startup and testing activities are included in the appropriate direct-cost line items.

\subsection{Owners' Cost (Account 94)}

Owners' cost (Account 94) includes the costs of the owner for activities associated with the overall management and integration of the project and other costs not included in the direct capital costs incurred prior to start of commercial operations as follows:

Management, engineering, integration, and OAVOC (Account 941). These expenses include cost of owner's staff for project management, engineering, integration, licensing, control, and QAVQC. It also includes supporting home office services such as estimating, planning and scheduling, and purchasing, as well as payment for outside supporting service directly associated with siting, building and startup of the plant.

Taxes and insurance (Account 942). These expenses cover all owner's nuclear and other insurance premiums, state and local taxes and sales taxes on purchased materials and equipment incurred during the course of the project, an's permits, licenses, and fees. Builder's all risk insurance is included in Account 914.

Spare parts and initial supplies (Account 943). This account includes the initial stock of supplies, consumables and spare parts needed for testing and startup operations and the plant inventories of fluids (water, lub oils), fuels (excluding nuclear fuel) and chemicals. Office furniture, communication equipment, transportation vehicles, laboratory equipment, house keeping gear, and other utility specific equipment are also part of this account. A good Reliability Centered Maintenance (RCM) program should be assumed and spare parts costs should reflect standard plants and modular plants and use of spare parts pools as applicable. Special coolants are not included here but in account 946. 
Staff Training and Startup (Account 944). The costs of the initial staffing and training of maintenance, operating, supervisory and administrative personnel are included in this account. This includes the preparation of all training materials and instruction costs, the salaries of the operating and the maintenance staff assigned to the plant prior to the plant acceptance, and their associated material and service expenses.

General and Administrative (G\&A) (Account 945). This includes administrative and general salaries plus related expenses, labor and certain regulatory expenses, outside services not applicable to other owner accounts, and public relation activities.

Capital equipment (Account 946). This item includes costs for any special coolants such as sodium, helium or heavy water for the initial loading of the plant systems.

It is preferred that owner's cost be estimated directly by consideration of the contents of each subaccount. If such an estimate is not possible, it is recommended that total owner's cost (Account 94) be estimated as $15 \%$ of the sum of the total direct and other indirect costs plus the cost of any special coolants.

\subsection{RM Home Office Engineering and Services (Account 95)}

This account includes all the costs of RM services and support that are over and above the normal charges included in the cost of an NSSS package (EEDB Account 220A).

\section{BASE CONSTRUCTION CAPITAL COST DOCUMENTATION}

Specific reporting requirements will be determined by DOE Program Management. The following documentation guidelines represent possible reporting requirements.

\subsection{Cost Reports}

As determined by DOE, separate cost estimates for the first commercial and NOAK plant may be required. Each separate cost set will be documented, separating the nuclear island costs from the balance of plant costs, using the EEDB tabular format and Code of Accounts according to the format in Table 2.6. Typical Code of Accounts for the ALMR, MHTGR and LWRs are provided in Appendices A-C. In addition to tabular cost data, a complete text description of the methods and assumptions used in developing the costs shall be submitted with the cost data. As discussed in Sect. 2.3, documentation on factory-produced 
equipment modules should include a work sheet for each different module. Examples of how the factory module costs fit into the EEDB code of accounts should be given. A suggested work sheet format is provided in Tatle 2.7.

\subsection{Plant Bulk Commodities Data}

To make commodity comparisons with competing plant concepts, the commodities listed below shall be reported as indicated at the two-digit EEDB level. Additional account detailed breakdowns should be retained by the proponent for review by DOE.

- Formwork [square feet (SF)] - Both wooden and metal forms are included.

- Structural steel [tons (TN)] - All structural steel is included regardless of whether it is used in modules or is field erected for both safety or nonsafety class structures.

- Reinforcing steel [tons (TN)] - The quantities for cadwelds and wire fabric are not included.

- Embedded steel [tons (TN)] - All embedded steel is included regardless of whether it is used in safety or nonsafety class structures.

- Structural concrete [cubic yards (CY)] - The costs for removable concrete plugs and for curbs and walks are not included. All structural concrete is included regardless of whether it is used in safety-class or non-safety-class structures, whether it is in internal or external walls, or whether it is in floor or elevated slabs.

- Concrete fill [cubic yards (CY)] - All fill concrete is included regardless of its location or purpose except when included as part of a module.

- Piping [linear $\mathrm{ft}(\mathrm{LF})$ ] - The following subcategories are required:

CS, SC, $<2$ 1/2-in. pipe

SS, SC, $<21 / 2$-in. pipe

CS, SC, $\geq 2$ 1/2-in. pipe

SS, SC, $\geq 2$ 1/2-in. pipe

CM, SC, $\geq 2$ 1/2-in. pipe

CS, NNS, <2 1/2-in. pipe

SS, NNS, <2 1/2-in. pipe

CS, NNS, $\geq 21 / 2$-in. pipe

SS, NNS, $\geq 21 / 2$-in. pipe

CM, NNS, $\geq 2$ 1/2-in. pipe 


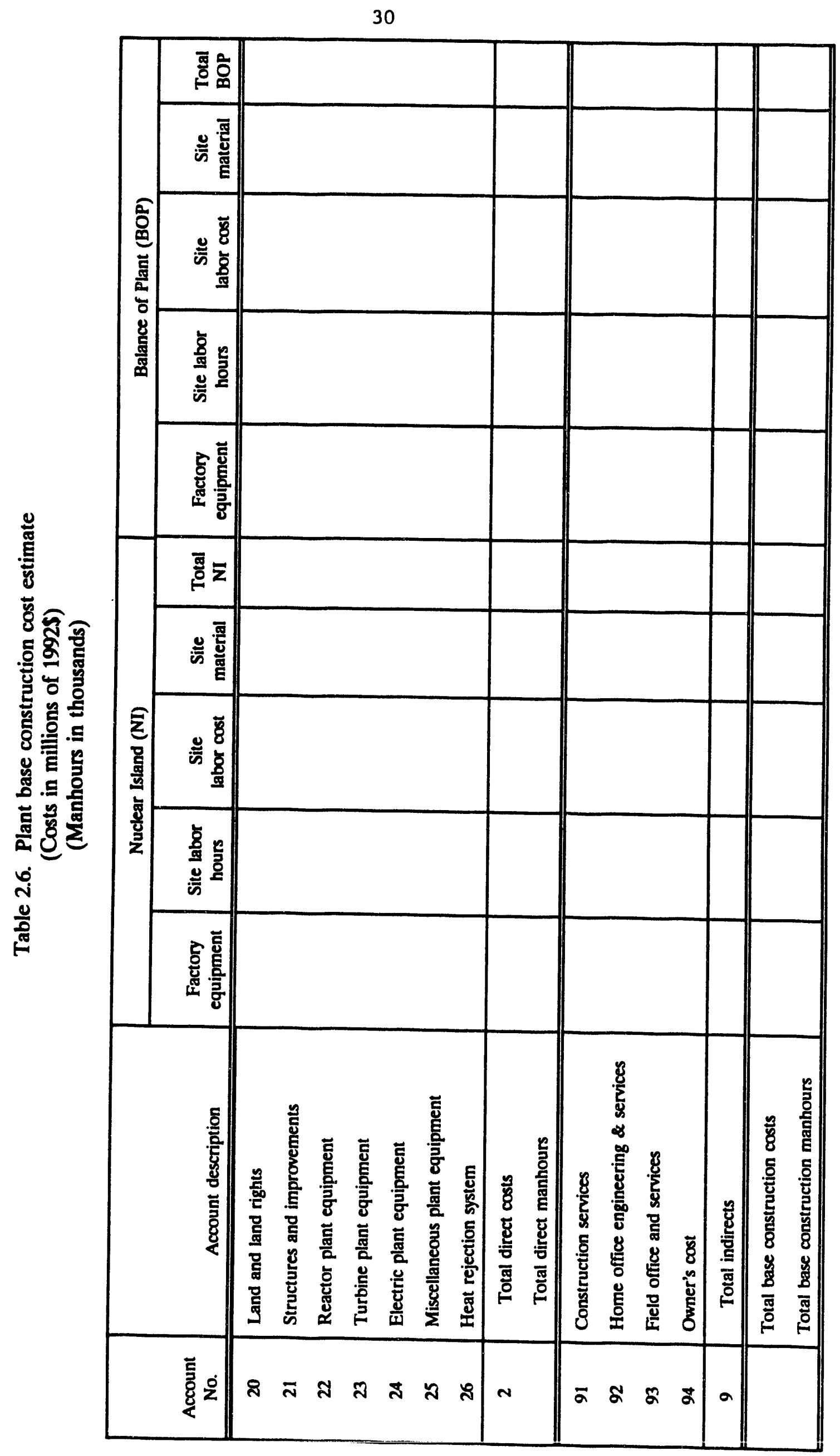




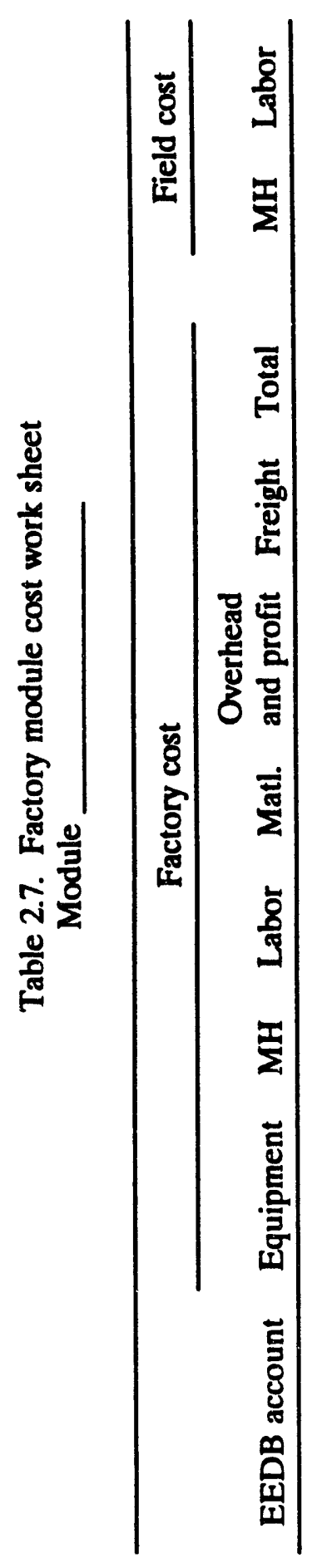


where

$$
\begin{aligned}
& \mathrm{CS}=\text { carbon steel, } \\
& \mathrm{SS}=\text { stainless steel, } \\
& \mathrm{CM}=\text { chrome moly steel, } \\
& \mathrm{SC}=\text { safety class, } \\
& \mathrm{NNS}=\text { non-nuclear-safety class. }
\end{aligned}
$$

These ten categories of piping do not include the following:

1. concrete, copper, cast iron, and galvanized pipe;

2. roof and floor drains piping;

3. sprinkler systems piping; and

๑. sanitary facilities piping.

- Power cable [linear feet (LF)]

This category should exclude lighting, cathodic protection, communication and heat tracing cable.

- Control cable and instrumentation cable.

- Wire and cable duct runs and containers [linear feet (LF)]-This account includes:

1. underground and above ground,

2. metallic and nonmetallic ducts, conduit, and

3. cable trays.

This category should exclude lighting, cathodic protection, communication and heat tracing cable.

Bulk commodities should be reported by EIEDB Code of Accounts as shown in Table 2.8.

\subsubsection{Plant Labor Requirements Data}

Craft and engineering labor requirements will be summarized by two-digit direct and indirect cost accounts as well as by total plant. Three-digit detail should be retained by the 


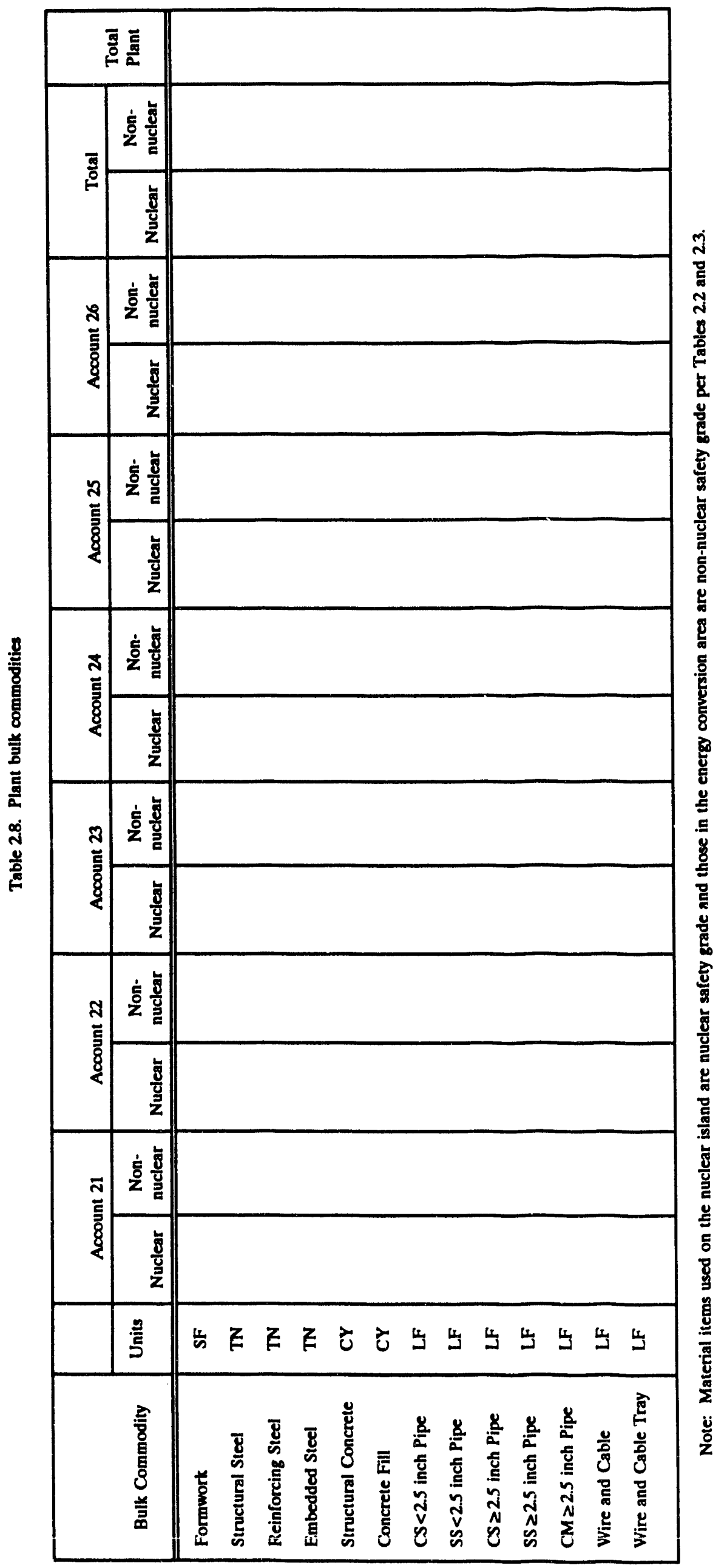


proponent for review by DOE. Specific, individual, manhour data will be provided for the following workers if utilized: boilermakers, bricklayers, carpenters, electricians, ironworkers, laborers, millwrights, operating engineers, painters, pipefitters, sheet metal workers, teamsters, other craft labor, engineering, and other noncraft home and field office labor. An example format is shown in Table 2.9.

Table 2.9. Plant labor requirments (manhours)

\begin{tabular}{|c|c|c|c|c|c|c|c|c|c|c|c|}
\hline \multirow[b]{2}{*}{ Labor type } & \multicolumn{10}{|c|}{ Account Number } & \multirow[b]{2}{*}{$\begin{array}{l}\text { Total } \\
\text { (b) }\end{array}$} \\
\hline & $\begin{array}{l}21 \\
\text { (b) } \\
\end{array}$ & $\begin{array}{l}22 \\
\text { (b) }\end{array}$ & $\begin{array}{l}23 \\
\text { (b) } \\
\end{array}$ & $\begin{array}{l}24 \\
\text { (b) } \\
\end{array}$ & $\begin{array}{l}25 \\
\text { (b) }\end{array}$ & $\begin{array}{l}26 \\
\text { (h) }\end{array}$ & $\begin{array}{l}91 \\
\text { (b) }\end{array}$ & $\begin{array}{l}92 \\
\text { (b) }\end{array}$ & $\begin{array}{l}93 \\
\text { (b) }\end{array}$ & $\begin{array}{l}94 \\
\text { (b) }\end{array}$ & \\
\hline \multicolumn{12}{|l|}{ Boilerwaker } \\
\hline \multicolumn{12}{|l|}{ Carpenter } \\
\hline \multicolumn{12}{|l|}{ Electrician } \\
\hline \multicolumn{12}{|l|}{ Iron worker } \\
\hline \multicolumn{12}{|l|}{ Laborer } \\
\hline \multicolumn{12}{|l|}{ Millwright } \\
\hline \multicolumn{12}{|l|}{ Operating eagineer } \\
\hline \multicolumn{12}{|l|}{ Pipefituer } \\
\hline \multicolumn{12}{|l|}{ Teamsier } \\
\hline \multicolumn{12}{|l|}{ Other craft labor } \\
\hline \multicolumn{12}{|l|}{ Engineering } \\
\hline \multicolumn{12}{|l|}{ Other Non-craft labor } \\
\hline Toul bours & & & & & & & & & & & \\
\hline
\end{tabular}

\section{DEVELOPMENT AND PROTOTYPE COST DOCUMENTATION}

The expected technology, design, prototype and certification costs (cost categories 1-6 in Sect. 2.1) will be itemized and expressed in constant dollars as defined in Sect. 2.2 (Item 2). These include all costs necessary to bring a concept to commercialization. Both a 50/50 and 90/10 confidence level estimate is desired. The timing of each cost item (at 50\% confidence level) shall be identified. The cash flows for these items may be provided on an annual basis. The report format is given in Table 2.10. The prototype construction cost should be reported at the two digit level. In addition to tabular cost data, a complete text description of the methods and assumptions used in developing the costs shall be submitted with the cost data. 
Table 2.10. Development/prototype costs (thousands of January 199_dollar)

Technology (R\&D) Costs

Standard Plant Design

Preliminary Design

Detailed Design

Prototype/Demonstration Module

Design

Construction

Direct Cost

Indirect Cost

Fuel

Testing and Operation

Standard Plant NRC Certification

Fuel Facility Desien and Certification

Factory FOAK Costs 


\section{TOTAL CAPITAL COST}

This section provides the ground rules for preparing an estimate of the total capital cost of a power plant. The base construction capital cost as described in the previous section is the starting point for costs developed in this section. The total capital cost shall be calculated in nominal dollars (including inflation) to the operation date and then adjusted to the reference years dollars.

\subsection{CONTINGENCY}

Contingency is a judgement adder to the base construction cost estimate to obtain a median cost estimate where there is equal probability that the true cost will be higher or lower than that cost (see Appendix $\mathrm{H}$ ). It includes an allowance for indeterminates and shall be calculated as a percentage of base construction cost. However, different percentages should be used for different systems or components in a plant because the amount of the contingency cost should be related to the stage or current level of design, the degree of technological advance represented by the design, and the quality/reliability level of the given system/component. As an example, it should be possible to estimate the cost for a standard mechanical draft cooling tower system more accurately (therefore requiring less contingency) than the cost for a new, innovative NSSS. To obtain consistency between various cost estimates, the percentages and requirements for their use are defined as follows.

A contingency cost of $25 \%$ of the applicable base cost shall be calculated for those systems that are innovative, that represent a substantial departure from previously built designs, or that require a high assurance of quality in construction and operation (e.g., nuclear-safety grade systems). For systems or components that are standard, current, off-theshelf technology items that are being applied in a normal, industrial non-nuclear-safety grade application, a contingency cost of $15 \%$ of the applicable base cost shall be calculated.

In cases where the scope and level of design provide for accurate quantity takeoffs and material and labor pricing, a lower contingency may be justified. Where design margins are substantial (for example, if a turbine-generator has a capability far higher than design output), a lower contingency may also be justified. In other cases where design definition is limited and prices are uncertain, a higher contingency value may be justified. The estimators 
may assess individual contingency amounts at the detailed account level. In those cases that the estimator departs from the basic $15 \%$ and $25 \%$ contingency rates, the details and reasons for the deviation shall be shown. The total contingency cost to be reported will be the sum of the contributions from each system or component category, and will include the expected value of cost items not explicitly covered in the detailed estimate (allowance for indeterminates). Contingency amounts for indirect base costs shall be calculated as above, based on an estimation of the proportion of the contingency reflected in that particular indirect ccist. The assumptions used in classifying the direct and indirect base costs according to the two categories must be fully documented by the estimator in detail.

The contingency estimate will be expressed in the same year's dollars as the base construction costs.

\subsection{CASH FLOW}

The cash flow requirements during the design and construction period will be determined on a quarterly basis for the prototype, first commercial and NOAK plants as required. The cash flow should be expressed in the same year's dollars as the overnight costs and should indicate whether contingency costs are included. Contingency costs must be explicitly included in the cash flow data if it is not assumed that contingency cash flow is proportional to base cost cash flow. Time effects such as escalation/inflation and interest should not be included in this cash flow data. As a result of the exclusion of escalation, the dates of cash flow may be expressed as either a relative or absolute date with respect to commercial operation. In addition, cash flows may be provided which include inflation.

\subsection{ESCALATION}

It is to be assumed that escalation during the design and construction period is occurring at the same rate as inflation; that is, there is no real escalation during this period. Costs will escalate between the reference year given in Sect. 2.2 (item 2) and the time the money is spent. It will be assumed that the money spent during any quarterly period will be paid at the beginning of the period. Total escalation during construction may be computed using the following formula 


$$
\underset{j=1}{\text { Allowance for }}=\sum_{j=1}^{J} C_{j}(1+i)^{l-1} \cdot-\sum_{j=1}^{J} C_{i}
$$

where

$$
\begin{aligned}
& \mathrm{j}=\text { quarterly cash flow period } \\
& \mathrm{J}=\text { total number of cash flow periods } \\
& \mathrm{C}_{\mathbf{j}}=\text { quarterly cash flow (base year dollars) during period } \mathrm{j} \text { assumed paid at } \\
& \text { beginning of period. } \\
& \mathrm{i}=\text { inflation rate, fraction } \\
& \mathrm{t}_{\mathrm{j}} \quad=\text { date at beginning of quarterly period (i.e., 2001.25) } \\
& \mathrm{t}_{\mathbf{0}} \quad=\text { reference date from Sect. } 2.1 \text { (i.e., 1992.0). }
\end{aligned}
$$

When the total cost is expressed in constant dollars for the year given in Sect. 2.2, escalation will be zero when expressed in constant dollars.

\subsection{INTEREST DURING CONSTRUCTION}

Once money is raised and the construction payment is made, a return must be paid on it until first operation. This return is sometimes referred to as the allowance for funds used during construction (AFUDC) or, more simply, the interest during construction (IDC). The IDC rate is the average cost of money $(\mathrm{X})$ and includes both equity and debt capital used to finance a project. The financial parameters for utility ownership given in Table 3.1 are those from the DOE NECDB ${ }^{5}$ and are to be used in determining IDC costs. It should be noted that the Tax Reform Act of 1986 no longer allows bond interest to be expensed (allowed as a tax deduction) during construction, but requires that it be fully capitalized. Thus, the average and not the tax-adjusted cost of money must be used in calculating interest during construction. 
Table 3.1. Financial parameters

\begin{tabular}{llll}
\hline \multicolumn{1}{c}{ Parameters } & Utility & Industrial $^{a}$ & High leverage $^{b}$ \\
\hline $\begin{array}{l}\text { Capitalization, \% } \\
\text { Debt }\end{array}$ & 50 & 30 & 70 \\
$\quad$ Preferred stock & 10 & - & - \\
$\quad$ Common equity & 40 & 70 & 30 \\
$\begin{array}{l}\text { Return on capitalization, \%/year } \\
\text { Debt interest }\end{array}$ & 9.7 & 9.7 & 13.0 \\
$\quad \begin{array}{l}\text { Preferred dividend } \\
\text { Common equity return }\end{array}$ & 9.0 & - & - \\
$\begin{array}{l}\text { Average cost of money, \%/year } \\
\text { Ratio of cost of debt/average cost of money }\end{array}$ & 14.0 & 17 & 22.0 \\
Inflation rate, \%/year & 11.35 & 14.81 & 15.7 \\
Real (inflation-adjusted) average cost of & 6.427 & 0.196 & 0.580 \\
$\quad$ money, \%/year & 5.0 & 5.0 & 5.0 \\
\hline
\end{tabular}
producer.

Typically financed industrial company or conservatively financed independent power

${ }^{b}$ Highly leveraged independent power producer or similar organization.

In addition to financial parameters for utility ownership, parameters for typically financed industrial ownership and for a more highly leveraged industrial ownership are also given. These latter two financial structures should cover the range for an independent power producers (IPP). An organization which is too highly leveraged (high debt ratio with debt of "Junk bond" quality) may not have the stability acceptable for operation of a nuclear plant. Costs are to be provided assuming utility ownership of the power plant. Any on-site fuel cycle facilities which are integral to the reactor plant are assumed to be utility owned and subject to utility financial assumptions. Off-site facilities, such as a central fuel cycle facility, and any module factories are to be assumed to be industrial owned and subject to the typical industrial parameters. Non-integral on-site fuel cycle facilities are also subject to industrial financial parameters. Nominal dollar interest will be calculated using the cash flow summaries developed in Sect. 3.2, and the inflation/escalation rates and average cost of money shown in Table 3.1. All interest costs will be capitalized up to the commercial operation date using the following method. 


$$
\operatorname{IDC}_{N}=\sum_{j=1}^{J} C_{j}(1+i)^{i-1} \cdot\left[(1+X)^{t^{-}-j}-1\right]
$$

where

$\mathrm{IDC}_{\mathrm{N}}=$ nominal dollar IDC cost

$t_{\text {op }} \quad=$ year of commercial operation

$\mathrm{X}$ = nominal dollar average cost of money.

The cash flows $\left(C_{j}\right)$ reflect quarterly, beginning-of-period borrowing. Although the IDC should be calculated in nominal dollars in order to correctly determine the fraction of the initial investment which may be depreciated for tax purposes, capital costs and interest costs should be expressed in constant dollars of the reference year given in Sect. 2.2. This IDC cost is given by

$$
I D C_{0}=\sum_{j=1}^{J} C_{j}\left[\left(1+X_{0}\right)^{1--\zeta}-1\right] .
$$

The real average cost of money, $X_{0}$, may be computed from the nominal dollar average cost of money, $X$ and the inflation rate, $i$, using the expression

$$
X_{0}=(1+X) /(1+i)-1
$$

If the cash flow data developed in Sect. 3.2 does not explicitly contain contingency costs, then the interest calculated using the cash flow summaries must be adjusted by the ratio of the total overnight cost to base construction cost as follows:

$$
\mathrm{IDC}_{\text {Lotal }}=\frac{\text { base cost }+ \text { contingency }}{\text { base cost }} \times \mathrm{IDC}_{\text {base oost }} .
$$




\subsection{TOTAL CAPITAL COST}

Total capital cost (TCC) will consist of the base construction cost as developed in Sect. 2, contingency, escalation, and interest during construction. All costs will be expressed in constant dollars in the year defined in Sect. 2.2 and separated into nuclear-safety grade, nonnuclear-safety grade, and total cost. Table 3.2 provides the format to be used in reporting total capital cost. In addition to constant dollars, costs may be expressed in nominal dollars. The total capital cost in nominal dollars differs from that in constant dollars by the total inflation between the reference year and year of startup,

$$
\mathrm{TCC}_{\mathrm{N}}=\operatorname{TCC}_{\mathrm{o}}(1+\mathrm{i})^{1}-\mathrm{-l}^{-1}
$$

where

$$
\begin{aligned}
& \mathrm{TCC}_{\mathrm{N}}=\text { nominal dollar total capital cost } \\
& \mathrm{TCC}_{\mathrm{o}}=\text { constant dollar total capital cost } \\
& \mathrm{i} \quad=\text { inflation rate. }
\end{aligned}
$$


Table 3.2. Plant total capital cost eatimate (thousands of January 199_doliars)

\begin{tabular}{|c|c|c|c|c|}
\hline $\begin{array}{c}\text { EEDB } \\
\text { Account } \\
\text { No. }\end{array}$ & Account description & $\begin{array}{l}\text { Nuclear- } \\
\text { safety } \\
\text { grade } \\
\text { cost }\end{array}$ & $\begin{array}{c}\text { Non-nuclear- } \\
\text { safety } \\
\text { srade } \\
\text { cost }\end{array}$ & $\begin{array}{l}\text { Total } \\
\text { cost }\end{array}$ \\
\hline \multirow[t]{2}{*}{$\begin{array}{l}20 \\
21 \\
22 \\
23 \\
24 \\
25 \\
26\end{array}$} & $\begin{array}{l}\text { Land and land rights } \\
\text { Structures and improvements } \\
\text { Reactor plant equipment } \\
\text { Turbine plant equipmeat } \\
\text { Electric plant equipment } \\
\text { Miecellaneous plant equipment } \\
\text { Main condenser heat rejection syatem }\end{array}$ & & & \\
\hline & Total direet cost & & & \\
\hline \multirow[t]{8}{*}{$\begin{array}{l}91 \\
92 \\
93 \\
94 \\
95\end{array}$} & $\begin{array}{l}\text { Construction services } \\
\text { AE home office engineering and services } \\
\text { Field office supervision and services } \\
\text { Owner's expenses } \\
\text { RM home office engineering and services }\end{array}$ & & & \\
\hline & Total indirect costs & & & \\
\hline & $\begin{array}{r}\text { BASE CONSTRUCTION COST - ToLaI S } \\
- \text { SAW(e) }\end{array}$ & & & \\
\hline & CONTINGENCY & & & \\
\hline & $\begin{array}{r}\text { TOTAL OVERNIGHT COST - Total S } \\
-\$ / k W(c)\end{array}$ & & & \\
\hline & ESCALATION & & & \\
\hline & INTEREST DURING CONSTRUCTION & & & \\
\hline & $\begin{array}{r}\text { TOTAL CAPITAL COST - Total S } \\
- \text { S/kW(e) }\end{array}$ & & & \\
\hline
\end{tabular}




\section{BUSBAR GENERATION COST}

This section provides guidance for developing the total levelized generation or busbar

cost for a power plant consisting of one or more building blocks. The method is equally applicable to a large monolithic plant.

\subsection{GENERAL ASSUMPTIONS AND METHODOLOGY}

A total plant energy generation cost or busbar cost includes the capital, nonfuel operation and maintenance $(O \& M)$, fuel and decommissioning costs and is generally expressed as a cost per unit energy. The general methodology to be followed in computing these levelized power generation costs can be found in the U.S. DOE document NECDB. ${ }^{5}$ The methodology uses year-by-year revenue requirements procedures together with levelization over the economic life of the plant. The levelized costs can either be expressed in dollars indexed to a reference year's buying power (constant dollar levelized cost) or in terms of a levelized cost which remains con stant over the life of the plant (nominal dollar levelized cost). In the constant dollar levelized approach, the year-by-year unit cost of electricity is assumed to rise in nominal dollar terms at the rate of inflation. The method used to determine this unit cost is to calculate the present value of all the plant revenue requirements (costs) and divide that amount by the present value of the energy generated over the life of the plant. Although either constant dollar or nominal dollar levelized costs will give an accurate comparison using the NECDB methodology, baseline results will be expressed in constant dollars of the reference year given in Sect. 2.2. Since the effect of taxes on the levelized cost depends on the inflation rate, the actual calculation should be done in nominal dollars including the projected inflation, and then adjusted to constant dollars.

Constant and nominal dollar levelized costs as defined with the NECDB methodology are directly related by the relation,

$$
\mathrm{LC}_{0}=\mathrm{LC}_{\mathrm{N}} \times \mathrm{CNCF}
$$


where

$\mathrm{CNCF}=$ Constant from Nominal cost factor

$$
=\left[1 /(1+i)^{L}\right] \times \frac{\operatorname{CRF}\left(d_{0}, 30\right)}{\operatorname{CRF}(d, 30)} \times \frac{\sum_{j=1}^{B} 1 /(1+d)^{i,-t_{1}}}{\sum_{j=1}^{B} 1 /\left(1+d_{0}\right)^{t^{-t_{l}}}}
$$

LC $\quad=$ constant dollar levelized costs

$\mathrm{LC}_{\mathrm{N}} \quad=$ nominal dollar levelized cost

$\mathrm{i} \quad=$ inflation rate

$\mathrm{L} \quad=$ time between first block startup $\left(\mathrm{t}_{\mathrm{op}}\right)$ and reference year $\left(\mathrm{t}_{\mathrm{o}}\right)$

B $\quad$ = number of blocks

$\operatorname{CRF}(a, b)=$ capital recovery factor at interest rate $a$ for period $b$.

$$
\begin{array}{ll} 
& =\frac{a}{\left[1-(1+a)^{-b}\right]} \\
d_{0} & =\text { constant dollar discount rate (real cost of money) } \\
d & =\text { nominal dollar discount rate (effective cost of money) } \\
30 & =\text { economic life (30 years). }
\end{array}
$$

The last ratio accounts for the lag time of subsequent blocks in a multiblock plant. This ratio becomes unity if all capacity is placed on line at the same time. Tabulations of the CNCF factor for utility, industrial, and IPP (high risk) financial factors are given in Appendix G for various values of $\mathrm{L}$, number of blocks and time increments between block startup.

The nominal dollar levelized cost as used in the above equation is that as defined in the NECDB and includes inflation. An alternate approach is to perform the analysis with inflation (in nominal dollars) but remove the inflation between the reference year and first block startup, or

$$
L C_{D}=\frac{L C_{N}}{(1+i)^{L}}
$$


This "deflated nominal dollar" approach is simple and may promote better acceptance in some sectors than either the pure nominal dollar or constant dollar figures.

Following some general requirements below, the treatment of each cost component will be discussed, and in Chap. 5, examples of the method with alternative plants will be given. 1. The power plant will be assumed to be utility owned and operated. Other applications may be shown in addition.

2. The levelized busbar cost will be expressed in constant dollars in the year defined in Sect. 2.2, Item 2. Nominal dollar or deflated nominal dollar levelized cost may also be shown.

3. The economic operating life of each unit (block) is assumed to be 30 -years for costestimating purposes. It is realized that plant lives of greater than 30-years are probable and that these longer plant lives will be of potential economic benefit. However, the ability to predict costs as well as technological changes into the distant future is questionable. An economic life of 30 -years is consistent with the maturity of long-term bonds.

4. The default capacity factor to be assumed is $80 \%$. A concept-specific capacity factor may be used if it is properly substantiated.

5. The present-worth discount rates using the financial parameters given in Table 3.1 are 9.57\%/yr (nominal) and 4.35\%/yr (real) for utility applications (see Table 4.1). Discount rates for typical industrial ownership are $13.74 \%$ /yr nominal and $8.32 \% / y r$ real. Discount rates for the more risky, highly leveraged IPP are $12.37 \% / y r$ nominal and $7.02 \% / y r$ real. These latter rates are less than those for the typical industrial ownership because of the large interest expense tax deduction received in the more highly leveraged IPP case. The general inflation rate is $5 \% / y r$.

6. Assumed use of any government-owned or -operated facility shall be costed at full cost recovery, including all direct costs, related indirect costs, depreciation, and any other related general and administrative costs. Inquiries regarding prices and charges to be assumed for specific materials and services shall be made to the Office of Advanced Reactor Programs, DOE-NE.

7. Costs will be calculated in a manner consistent with the Tax Reform Act of 1986. 
Table 4.1. Fixed charge rate input parameters

\begin{tabular}{|c|c|c|c|}
\hline Parameters & Utility & Industrial $^{a}$ & $\mathrm{IPP}^{b}$ \\
\hline Effective (tax-adjusted) cost of money, \%/yr & 9.57 & 13.74 & 12.37 \\
\hline Real cost of money, \%/yr & 4.35 & 8.32 & 7.02 \\
\hline Inflation rate, $\% / y r$ & 5 & & \\
\hline Federal income tax rate, $\% / y r$ & 34 & & \\
\hline State income tax rate, \%/yr & 4 & & \\
\hline Combined state and federal tax rate, $\%$ & 36.64 & & \\
\hline Property tax rate, $\%$ of capital investment/yr & 2 & & \\
\hline Interim replacement rate, $\%$ of investment/yr & 0.5 & & \\
\hline Book/analysis life, yr & 30 & & \\
\hline Tax depreciation duration, yr & 15 & & \\
\hline Tax depreciation method ${ }^{e}$ & \multicolumn{3}{|c|}{$150 \%$ declining balance } \\
\hline Accounting method & \multicolumn{3}{|c|}{ Normalized } \\
\hline
\end{tabular}

Typically financed industrial company or conservatively financed Independent Power Producer.

${ }^{b}$ Highly leveraged independent power producer or similar organization.

'See Table 2.5, p. 21 of Ref. 5 for details.

\section{CAPITAL COST}

Under the assumption of equal annual energy generation, the equation for calculating the nominal dollar levelized capital cost can be expressed as

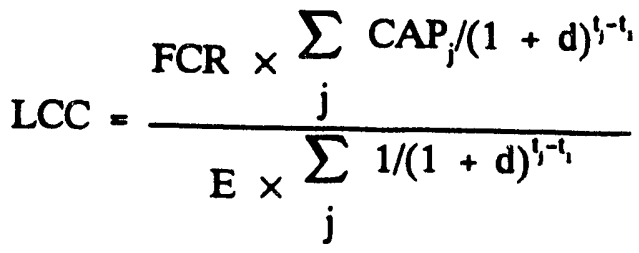


where

LCC = levelized capital cost in nominal dollars,

FCR = nominal dollar fixed charge rate,

$\mathrm{CAP}_{\mathrm{j}}=$ total capital cost for unit $\mathrm{j}$ in nominal dollars as determined in Sect. 3 ,

$t_{1}=$ commercial operation date for unit 1 ,

$t_{j} \quad=$ commercial operation date for unit $j$,

$\mathrm{E} \quad=$ annual energy generation for single unit.

For a single-unit (block) plant, the previous equation reduces to

$$
\mathrm{LCC}=(\mathrm{FCR} \times \mathrm{CAP}) / \mathrm{E} .
$$

A fixed charge rate is used to properly account for return on capital, depreciation, interim replacements, property tax, and income tax effects. The fixed charge rate is discussed in detail in Sect. 3.3 and Appendix B of Ref. 5. The fixed charge rate is dependent upon the fraction of the total plant investment that is eligible for tax depreciation (tax depreciation may not be taken on equity financing costs). The fixed charge rate can be calculated using the NECDB methodology as implemented in an IBM type PC code. ${ }^{9}$ However, if this code is not available the relationships given below can be used to determine the applicable fixed charge rate for utility and industrial applications (see Tables 3.1 and 4.1 for financial structure). The fixed charge rate varies depending on the ratio of total interest during construction (including equity financing) to total capital cost (all expressed in nominal dollar terms) as follows,

Utility: FCR $=0.01795 \times($ IDC/TCC $)+0.15862$

Industrial: $\mathrm{FCR}=0.02783 \times(\mathrm{IDC} / \mathrm{TCC})+0.21460$

IPP: $\mathrm{FCR}=0.01416 \times(\mathrm{IDC} / \mathrm{TCC})+0.019548$

where

$$
\begin{aligned}
& \mathrm{IDC}=\text { nominal dollar interest during construction, } \\
& \mathrm{TCC}=\text { nominal dollar total capital cost. }
\end{aligned}
$$

The input parameters given in Table 4.1 were used to develop the above relationship.

Constant dollar fixed charge rates may be determined from the nominal dollar rates by multiplying by the ratio of the constant to nominal dollar capital recovery factors $(0.590$ for utilities, 0.652 for industrials, and 0.633 for IPPs). 


$$
F C R_{0}=\frac{C R F\left(d_{0}, 30\right)}{C R F(d, 30)} \times F C R
$$

where

$\mathrm{FCR}_{\mathrm{o}}=$ constant dollar fixed charge rate.

The capital recovery factor ratio is given in Appendix G (Table G.10) for various nominal dollar discount rates and inflation rates.

\subsection{O\&M COSTS}

This section provides guidance on the development of the nonfuel O\&M costs. The O\&M costs are incurred from commercial operation and throughout the operating life of the plant. For these studies only the first 30 years of operation will be considered.

Certain O\&M costs, such as those for materials and supplies, can be at least partially dependent upon the amount of energy generated by the plant. These variable costs should be added to the fixed costs, which are independent of generation, to arrive at a total annual O\&M cost.

The O\&M cost estimate should provide, as a minimum, the detail shown in Tables 4.2 and 4.3 for fixed, variable, and total O\&M costs as applicable. Site staff requirements data should also be reported as shown in Table 4.4. For multi-block plants, the annual O\&M costs and staffing requirements are to be specified by block as well as for the total plant.

The O\&M cost estimate should be the expected costs and expressed in constant dollars for the year defined in Sect. 2.2. It is to be assumed that the escalation rate for O\&M costs is equal to the rate of inflation, such that there is no real escalation for O\&M costs. Certain O\&M cost factors are design independent and/or owner related. Data for these factors are provided below and should be used in the development of the annual O\&M costs. 
Table 4.2. Nonfuel O\&M expense accounts

\begin{tabular}{ll}
\hline \multicolumn{1}{c}{ Accouni } & \multicolumn{1}{c}{ Description } \\
\hline On-site staff & $\begin{array}{l}\text { Includes all personnel assigned to the plant site. See } \\
\text { Table 4.4 for typical categories. }\end{array}$ \\
Maintenance materials & $\begin{array}{l}\text { Can be either variable or fixed costs. Consist of } \\
\text { noncapitalized hardware used in normal maintenance } \\
\text { activities. }\end{array}$ \\
Supplies and expenses & $\begin{array}{l}\text { Can be either variable or fixed costs. Consist of } \\
\text { consumable materials and other unrecoverable items such } \\
\text { as make-up fluids, chemicals, gases, lubricants, office and } \\
\text { personnel supplies and monitoring and record supplies; } \\
\text { costs for on-site radioactive and non-radioactive waste } \\
\text { management activities; costs for disposal of absorbers and } \\
\text { other replacable reflector/shield assemblies. }\end{array}$ \\
Off-site technical support & $\begin{array}{l}\text { Activities by personnel not assigned full time to the plant } \\
\text { site; examples are safety reviews, off-site training, } \\
\text { environmental monitoring, meteorological surveys, power } \\
\text { planning, fuel studies, and other owner home office } \\
\text { activities directly supporting the plant. }\end{array}$ \\
P.nsions and benefits & $\begin{array}{l}\text { Costs of pensions and benefits, including worker's } \\
\text { compensation insurance, provided for the on-site and off- } \\
\text { site staff. } \\
\text { NRC annual fees and review costs as well as other routine } \\
\text { safety, environmental, and health physics inspections. }\end{array}$ \\
Regulatory fees & $\begin{array}{l}\text { Costs for commercial and government liability insurance, } \\
\text { property damage insurance, and replacement power } \\
\text { insurance. } \\
\text { Administrative and general salaries and related expenses. }\end{array}$ \\
Other A\&G &
\end{tabular}


Table 4.3. Annual O\&M cost format

\begin{tabular}{|c|c|c|c|}
\hline \multirow[b]{2}{*}{ Item } & \multicolumn{3}{|c|}{1992 Sk/yr } \\
\hline & 1 block & 2 blocks & Etc. \\
\hline \multicolumn{4}{|c|}{ Direct power generation } \\
\hline \multicolumn{4}{|l|}{ On-site staff } \\
\hline \multicolumn{4}{|l|}{$\begin{array}{l}\text { Maintenance materials } \\
\text { Fixed } \\
\text { Variable }\end{array}$} \\
\hline \multicolumn{4}{|l|}{$\begin{array}{l}\text { Supplies and expenses } \\
\text { Fixed } \\
\text { Variable }\end{array}$} \\
\hline \multicolumn{4}{|l|}{ Off-site technical support } \\
\hline \multicolumn{4}{|c|}{ Administrative and general } \\
\hline \multicolumn{4}{|l|}{ Pensions and benefits } \\
\hline \multicolumn{4}{|l|}{ Nuclear regulatory fees } \\
\hline \multicolumn{4}{|l|}{ Nuclear insurance premiums } \\
\hline \multicolumn{4}{|c|}{ Other administrative and general expenses } \\
\hline Total annual O\&M costs & & & \\
\hline
\end{tabular}


51

Table 4.4. On-site staff requirements

\begin{tabular}{|c|c|c|c|c|}
\hline \multirow[b]{2}{*}{ Category } & \multirow{2}{*}{$\begin{array}{c}\text { Salarye } \\
1992 \\
\text { S/yr }\end{array}$} & \multicolumn{3}{|c|}{ Number of persons } \\
\hline & & 1 Block & 2 Blocks & Etc. \\
\hline $\begin{array}{l}\text { Plant manager } \\
\text { Administrative Division: }\end{array}$ & 122,000 & & & \\
\hline Manager & 85,000 & & & \\
\hline Environmental control & 54,000 & & & \\
\hline Emergency plant public relations & 54,000 & & & \\
\hline Training & 59,000 & & & \\
\hline Safety and fire protection & 50,000 & & & \\
\hline Administrative services & 32,400 & & & \\
\hline Health services & 32,400 & & & \\
\hline Security & 29,100 & & & \\
\hline Subtotal & & & & \\
\hline \multicolumn{5}{|l|}{ Operations Division: } \\
\hline Manager & 85,000 & & & \\
\hline Shift supervision & 62,600 & & & \\
\hline Shift operators & 52,500 & & & \\
\hline Results engineering & 52,500 & & & \\
\hline \multicolumn{5}{|l|}{ Subtotal } \\
\hline \multicolumn{5}{|l|}{ Maintenance Division: } \\
\hline Manager & 85,000 & & & \\
\hline Supervision & 58,100 & & & \\
\hline Diagnostic engincering & 52,500 & & & \\
\hline Crafts (Mech., Elect., I\&C, ISI) & 41,300 & & & \\
\hline Annualized peak maintenance & 41,300 & & & \\
\hline Annualized refueling & 44,700 & & & \\
\hline Radwaste & 41,300 & & & \\
\hline Quality Assurance & 44,700 & & & \\
\hline Planning & 44,700 & & & \\
\hline Grounds and housekeeping & 29,500 & & & \\
\hline Warehouse & 38,000 & & & \\
\hline \multicolumn{5}{|l|}{ Subtotal } \\
\hline \multicolumn{5}{|l|}{ Technical Division: } \\
\hline Manager & 85,000 & & & \\
\hline Reactor engineering & 62,600 & & & \\
\hline Radioachem and water chem & 58,100 & & & \\
\hline Licensing and regulatory assurance & 53,600 & & & \\
\hline Engineering & 53,600 & & & \\
\hline Technicians & 43,600 & & & \\
\hline Health physics & 44,800 & & & \\
\hline \multicolumn{5}{|l|}{ Subtotal } \\
\hline Total staff & & & & \\
\hline
\end{tabular}

"Add $10 \%$ to salaries for social security and unemployment insurance premiums. 
Annual on-site staff salaries to be assumed are shown in Table 4.4 with an additional $10 \%$ to be added for social security tax and unemployment insurance premiums. For off-site technical support, an average annual salary of \$62,000/person (1992\$) should be assumed with an additional $70 \%$ added to the total (10\% for social security tax and unemployment insurance and a $60 \%$ overhead allowance for office space, utilities and miscellaneous expenses). The pension and benefits account which includes workman's compensation insurance should be calculated as $25 \%$ of the sum of on-site and off-site direct salaries (excluding off-site over-head). Annual nuclear regulatory fees should be assumed to be $\$ 2.8$ million (1992\$) per block (unit) for the first commercial plants and \$1.4 million for the NOAK plants. Estimates of annual premiums for nuclear plant insurance for medium-sized [350-700 MW(e)] advanced nuclear plants are provided in Table 4.5. Finally, other administrative and general expenses should be calculated as $15 \%$ of the direct power generation accounts (i.e., $15 \%$ of the sum of on-site staff, maintenance materials, supplies and expenses, and off-site technical support costs).

Table 4.5. Annual premiums for nuclear power plant insurance for medium-size [350-700 MW(e)] advanced nuclear plants

(January 1992 dollars)

\begin{tabular}{|c|c|c|c|c|}
\hline & \multicolumn{4}{|c|}{ Number of blocks per site } \\
\hline & 1 & 2 & 3 & 4 \\
\hline $\begin{array}{l}\text { Public liability } \\
\text { Commercial ( } \$ 200 \text { million) } \\
\text { Self insurance }\end{array}$ & $\begin{array}{r}\text { S } 600,000 \\
-0\end{array}$ & $\begin{array}{r}\text { S } 900,000 \\
-0\end{array}$ & $\begin{array}{r}\$ 1,200,000 \\
-0\end{array}$ & $\begin{array}{r}\$ 1,500,000 \\
-0\end{array}$ \\
\hline $\begin{array}{l}\text { Plant property damage } \\
\text { Primary ( } \$ 500 \text { million) } \\
\text { Secondary ( } \$ 600 \text { million) }\end{array}$ & $\begin{array}{l}2,380,000 \\
1,200,000 \\
\end{array}$ & $\begin{array}{r}3,640,000 \\
1,400,000 \\
\end{array}$ & $\begin{array}{r}4,900,000 \\
1,600,000 \\
\end{array}$ & $\begin{array}{l}6,160,000 \\
1,800,000 \\
\end{array}$ \\
\hline Total & $\$ 4,180,000$ & $\$ 5,940,000$ & $\$ 7,700,000$ & $\$ 9,460,000$ \\
\hline
\end{tabular}

To obtain the nominal dollar levelized cost for O\&M, the present worth of the annual plant O\&M costs must be determined by discounting, at the nominal cost of money, the annual O\&M cost back to the commercial operation date of the first unit (block). In equation form 


$$
P W O M=\sum_{a} \frac{O M_{n}}{(1+d)^{2}},
$$

where

PWOM = present worth of O\&M costs,

$\mathrm{OM}_{\mathrm{n}} \quad=$ annual total plant O\&M costs (in nominal dollars)

n = time index relative to plant startup.

If the O\&M costs are escalating at the inflation rate, then

$$
O M_{n}=(1+i)^{L}(1+i)^{n} O M_{0, n}
$$

where

L = time between reference year and startup of first block,

$O M_{0, \mathrm{a}}=O \& M$ cost in year $\mathrm{n}$ in Reference years dollar.

So

$$
P W O M=(1+i)^{L} \sum_{i} \frac{O M_{0, n}}{\left(1+d_{0}\right)^{n}}
$$

where

$d_{o}=$ constant dollar (real) discount rate.

This present-worth cost is then divided by the present worth of the total energy generation as shown below to arrive at the levelized cost.

$$
L C O M=\frac{\operatorname{CRF}(d, 30) \times P W O M}{E \times \sum_{j} 1 /(1+d)^{j^{j-t_{1}}}},
$$


where

$$
\begin{aligned}
& \text { LCOM }=\text { levelized O\&M cost in nominal dollars, } \\
& \text { PWOM }=\text { present worth of annual O\&M costs, } \\
& \text { CRF }=\text { capital recovery factor }
\end{aligned}
$$

Examples using this methodology are presented in Sect. 5.

\subsection{FUEL COSTS}

The expected fuel cycle costs for the first 30 years of a power plant's operation shall be estimated. The fuel cycle will be subdivided into its components, such as uranium, thorium or plutonium purchase, conversion, enrichment, fabrication, reprocessing, and waste disposal. Costs and quantities will be reported for each component over the assumed operating period. All assumptions, such as unit costs, processing losses, mass balance data, and lead and lag times for costs, shall be reported. A complete description of the fuel cycle cost analysis shall be prepared. Additional requirements are listed below.

1. Fuel management plans including mass flows and their timing into and out of the reactor must be provided for all fuel, blanket, and absorber elements.

2. The capital and $O \& M$ costs for the initial and subsequent fuel cycle facilities assumed to support the operation of the first commercial through NOAK plants, must be estimated following the procedures given in Sects. 3 and 4 of this document. This includes, but is not limited to, documenting the direct and indirect costs, the contingency cost, cash flow, and interest during construction in the capital cost of the fuel cycle facilities. Such fuel cycle facilities include fuel reprocessing plants and fuel fabrication plants which are not currently commercially available. The AFUDC and fixed charge rate for non-government owned facilities should be calculated using industrial rates. If the facility is an on-site facility and is utility owned and a physical part of the power plant (part of utility rate-base), utility financial rates may be used. An allowance for equipment replacement will be included if the equipment has a design life of less than the 30-year facility operating life.

3. A deployment plan for the fuel cycle facilities should be developed and coordinated with fuel delivery requirements of the plants to be supplied by the facility. Capital and operating cash flows during the deployment period should be developed. 
4. The economic lifetime of any co-located, integral fuel recycle facility shall not be in the excess of the time necessary to service fuel from a specific power plant site over its assumed economic life. (It is to be assumed that each power block has a $\mathbf{3 0}$ year economic operating life.)

5. The costs for absorber and other replaceable reflector/shield elements must be included in the fuel cycle cost estimates.

6. The levelized cost for an equilibrium cycle fuel, blanket, shield, and absorber assembly shall be reported in \$/assembly and \$/kg HM if applicable. The costs must be further subdivided into components related to fissile material procurement, facility capital amortization, fuel facility O\&M costs, hardware costs, fresh heavy metal and transportation, as applicable.

7. It shall be assumed that spent fuel leaving the reactor (including the final core discharge) has no economic value in that state. The value of any fissile plutonium or uranium-233 from spent fuel is to be based on the cost of its recovery. The cost basis/purchase price for recycled fissile material shall be a levelized average cost based on the cost to reprocess (including related facility capital amortization) and the total fissile output of the fuel cycle facility.

8. The source, availability, and cost of the reactor fuel needs to be documented if a fuel other than U-235 used. For example, if fissile plutonium is the reactor fuel, then the method and cost of obtaining this fuel needs to be shown. If the NOAK plant is to use excess fissile material from other plants of its type for its start-up fuel, then the time and extent of this recycle fuel availability needs to be shown for representative scenarios.

9. Consistent with the 1986 Tax Reform Act, no investment tax credits may be taken.

10. The cost of each batch of fuel will be capitalized and depreciated for tax purposes by either a $200 \%$ declining balance method over five years using the IRS half-year convention (see Table 2.6, page 21, Ref. 5) or a units-of-production (energy proration) basis.

11. The combined federal and state tax rate to be assumed is $36.64 \%$.

The following unit costs should be assumed in developing fuel cycle costs:

1. Uranium ore price shall be $\$ 25.00 / 1 b$ (1992 \$). This price is assumed to escalate at the 
1. Uranium ore price shall be $\$ 25.00 / 1 \mathrm{~b}$ (1992 \$). This price is assumed to escalate at the rate of inflation (no real escalation) over the economic life of the plant.

2. Uranium conversion price shall be $\$ 10.00 / \mathrm{kg} \mathrm{U}(1992 \$)$ with escalation equal to inflation (i.e., no real escalation).

3. Enrichment price shall be $\$ 125 / \mathrm{kg}$ SWU (1992 \$) for uranium enrichments up to $10.5 \%$. The incremental enrichment price above $10.5 \%$ enrichment shall be $\$ 925 / \mathrm{kg}$ SWU. The price escalation shall be equal to inflation (i.e., no real escalation).

4. Fuel fabrication price for extended burnup LWR fuel in 2005 is $\$ 260 / \mathrm{kg}$ HM (1992. dollars) with escalation equal to inflation (i.e., no real escalation).

5. The spent fuel or waste disposal fee is 1 mill/kWh (1992 \$) with no real escalation.

6. Escalation will be at the rate of inflation for all other fuel cycle components (i.e., no real escalation).

Additional or revised cost assumptions may be provided by DOE.

Capital cost and amortization assumptions for all fuel cycie facilities (e.g., MHTGR fuel fabrication or ALMR fuel reprocessing/recycle/fabrication facilities) shall be fully documented.

As each batch of fuel is capitalized for tax purposes, the fuel cycle analysis must be performed in nominal rather than constant dollar terms to properly reflect tax depreciation. Finally, all fuel cycle costs for the power plant should be present-worthed to plant startup for use in developing the total busbar cost. The methodology to obtain the present worth of the fuel costs is provided in Sect. 3 of the NECDB. ${ }^{5}$ A computer code such as the PC version 9 of the REFCO-83 code $^{10}$ may be used to help calculate the fuel cycle costs.

Similar to the calculation of levelized O\&M costs, the nominal dollar levelized fuel cost can be expressed as

$$
L C F C=\frac{\operatorname{CRF}(d, 30) \times P W F C}{E \times \sum_{j} 1 /(1+d)^{t^{t-t_{i}}}},
$$

where

LCFC = levelized fuel cost in nominal dollars, PWFC = present worth of annual fuel costs. 


\subsection{DECOMMISSIONING}

The cost for plant decommissioning should be estimated and included in the busbar cost. A separate analysis is desirable, however, in the absence of a specific decommissioning estimate, a default cost that is a function of block (unit) size may be used. The default values are based on the NRC minimum prescribed decommissioning costs developed by PNL. Separate costs as a function of unit thermal output were prescribed for PWRs and BWRs. In the previous cost guidelines, ${ }^{2}$ these costs, were increased by inflation and also by the estimated cost of dismantlement. For these guidelines, the previous relations were increased by about $1 / 3$ to account for cost increases since 1989 . For reactor types other than BWRs or PWRs an average value should be used. The cost equations are

PWR: Cost (million \$) $=145+0.020(\mathrm{P}-1200)$

BWR: Cost $($ million $\$)=185+0.020(P-1200)$

Other: Cost $($ million $\$)=165+0.020(P-1200)$

where $\mathbf{P}=$ block thermal power MWt. Costs are constant at the $1200 \mathrm{MWt}$ and $3400 \mathrm{MWt}$ values for block power levels below $1200 \mathrm{MWth}$ and above $3400 \mathrm{MWt}$. These costs are assumed to increase at the rate of inflation.

It should be assumed that an external sinking fund consisting of high grade tax-free municipal bonds yielding $7.0 \% / y r$ nominally will be established to accumulate the funds necessary for decommissioning. Although the plant will probably have a life exceeding the 30-year analysis life, it will be assumed that the funds necessary for decommissioning the plant will be accumulated over the 30 -year analysis life. The present worth of this decommissioning fund in nominal dollars can be calculated using the expression

$$
P W D C=\frac{D O_{0} \times(1+i)^{L} \times \operatorname{SFF}(7.0,30) \times \sum_{j} 1 /\left(1+d_{0}\right)^{t^{-1} t_{1}}}{\left(1+d_{0}\right)^{30} \times \operatorname{SFF}(d, 30)}
$$

where

$$
\begin{aligned}
& \text { PWDC = present worth of total decommissioning costs; } \\
& \mathrm{DC}_{\mathrm{o}} \quad=\text { decommissioning cost in reference year's dollars for one block; } \\
& \mathrm{SFF}(r, t)=\text { sinking fund factor at rate } r \text { for } t \text { years, that is, } r /\left[(1+r)^{\prime}-1\right]
\end{aligned}
$$


Following the treatment used for O\&M and fuel costs, the levelized cost of decommissioning can be expressed as

$$
\operatorname{LCDC}=\frac{\operatorname{CRF}(d, 30) \times P W D C}{E \times \sum_{j} 1 /(1+d)^{t_{j}-t_{1}}},
$$

where

$\mathrm{LCDC}=$ levelized decommissioning cost in nominal dollars.

An example of this calculation is given in Sect. 5.

\subsection{TOTAL BUSBAR COST}

The levelized total busbar cost is simply the sum of the levelized costs for capital, O\&M, fuel, and decommissioning as determined previously,

$$
\mathrm{LC}=\mathrm{LCC}+\mathrm{LCOM}+\mathrm{LCFC}+\mathrm{LCDC} .
$$

The above procedure calculates nominal dollar levelized costs. Constant dollar levelized costs are needed for DOE reporting purposes since these costs are indexed to reference year cost levels. The nominal dollar costs may be converted to constant dollar values using the equation defined in Sect. 4.1.

$$
\begin{aligned}
& \mathrm{LC}_{\mathrm{o}}=\mathrm{LC} \times \mathrm{CNCF} \\
& \mathrm{LCOM}_{\mathrm{o}}=\mathrm{LCOM} \times \mathrm{CNCF}
\end{aligned}
$$

etc.

where

$$
C N C F=(1+i)^{-i} \frac{\operatorname{CRF}\left(d_{0}, 30\right)}{\operatorname{CRF}(d, 30)} \times \frac{\sum_{j} 1 /(1+d)^{t_{1}-t_{1}}}{\sum_{j} 1 /\left(1+d_{0}\right)^{t_{1}-t_{1}}}
$$

This factor is tabulated in Appendix $G$ for utility and industrial applications. Deflated nominal dollar levelized costs may be calculated from nominal dollar costs using the expression 


$$
L C_{D}=(1+i)^{-L} \times L C
$$

Examples of the development of total busbar costs for alternative plants are provided in the next chapter. 


\section{EXAMPLE CALCULATIONS}

This chapter provides examples of the method used to estimate the busbar costs for alternative power plant configurations. Costs are provided for fossil-fired generation and are for reference purposes only. Comparisons of advanced reactor concept costs with those for alternatives are not required. To further understand how the levelized costs are obtained, a description of the calculational procedure is provided below for example configurations. Other configurations can be determined in a similar manner. The alternative plants used for the example calculations are for coal- and gas-fired generation starting commercial operation in the year 2010. The plants include a pulverized coal-fired (PC) plant, and a combined cycle combustion turbine (CCCT) plant:

$$
\begin{aligned}
& \text { 600-MW(e) PC plant } \\
& 500-\mathrm{MW}(\mathrm{e}) \mathrm{CCCT} \text { plant } \\
& 2 \times 600-\mathrm{MW}(\mathrm{e}) \mathrm{PC} \text { plant }
\end{aligned}
$$

The following general assumptions apply to the development of the levelized busbar generation costs for the alternative power plants:

1. The levelized busbar cost will be expressed in constant 1992 dollars. In addition, costs may be expressed in nominal dollars or deflated nominal dollars.

2. The capacity factor for all alternative plants is assumed to be $80 \%$.

3. The operating life of each unit is assumed to be 30 years for cost estimating purposes.

4. The present-worth discount rate is the utility ownership rates of $9.57 \% / y r$ (nominal) and $4.35 \% / y r$ (real). The general inflation rate is $5 \% / y r$.

\subsection{COST DATA}

The capital and operating costs for these plants were taken from a recent USCEA study. " The basis for these costs may not be consistent with the groundrules presented in these guidelines. The levelized costs calculated in this section therefore may not be directly comparable to costs estimated using these groundrules and absolute comparisons with these plants should be avoided. 


\subsubsection{Capital Cost}

The capital cost estimates for the example power plants listed previously are given in Table 5.1. The overnight cost data and total construction times for these plant were taken from the USCEA study. The AFUDC (interest during construction) shown Table 5.1 was calculated using the procedures recommended in these groundrules and assuming a chopped cosine cash flow distribution where $5 \%$ of the fossil plant cost was expended during the preconcrete pour period. This period is assumed to be 12 months for the first PC coal and 6 months for the CCCT plant and second PC coal unit and are included in the construction times shown. The final capitalized cost differs somewhat from those reported in the USCEA study due to differences in the cost of money and cash flow assumptions. The second unit of the PC coal-fired plant is assumed to come on line 1 year after the first unit.

Table 5.1. Example power plant capital cost data

\begin{tabular}{lccc}
\hline \multicolumn{1}{c}{ Plant type } & $\begin{array}{c}\text { Overnight } \\
\text { capital cost } \\
(1992 \$ / k W e)\end{array}$ & $\begin{array}{c}\text { Construction } \\
\text { period } \\
\text { (months) }\end{array}$ & $\begin{array}{c}\text { Total } \\
\text { capital }^{\text {cost }^{a}}\end{array}$ \\
\hline 1-600 MW(e) PC plant & 1268 & 42 & 1394 \\
Second 600 MW(e) PC unit & 1074 & 36 & 1180 \\
Combined 2-unit PC plant & 1171 & 48 & 1287 \\
500 MW(e) CCCT plant & 532 & 24 & 565 \\
\hline
\end{tabular}

${ }^{a}$ Nominal dollar cost for startup in any year, $\mathrm{Y}$, calculated by adjusting for inflation between 1992 and year $\mathrm{Y}$. For reference inflation rate of 5\%:

$$
\begin{aligned}
\operatorname{Cost}(\mathrm{Y}) & =\operatorname{cost}(1992) \times 1.05^{(\mathrm{Y} .1992)} \\
& =2.407 \times \operatorname{cost}(1992) \text { for } 2010 \text { startup. }
\end{aligned}
$$

The pulverized coal-fired plant has precipitators and wet limestone scrubbers. All plants have mechanical draft cooling towers. 


\subsubsection{O\&M Cost}

O\&M cost estimates are needed for estimating the alternative plant configurations under consideration. The O\&M cost estimates are again based on the USCEA study ${ }^{11}$ and are given in Table 5.2. The procedure using the data in Table 5.2 to produce a cost estimate for an alternative plant is discussed in Sect. 5.6.

Table 5.2. Alternative power plant O\&M cost data ${ }^{a}$

\begin{tabular}{cc}
\hline Plant type & $\begin{array}{c}\text { Annual O\&M cost } \\
\text { (millions 1992\$) }\end{array}$ \\
\hline 1-600 MW(e) PC plant & $38.1^{\mathrm{c}}$ \\
2-600 MW(e) PC plant & 70.8 \\
1-500 MW(e) CCCT plant & 7.8 \\
\hline
\end{tabular}

${ }^{a}$ At $80 \%$ capacity factor.

${ }^{b}$ Based on Ref. 11.

Includes a $\$ 500 /$ ton sulfur tax.

\subsubsection{Fuel Costs}

The price assumptions for fossil fuels are shown in Table 5.3. The 1992 prices are near current (1992) price levels. The real price escalation rates are from the supplement to the EIA 1992 Annual Energy Outlook. ${ }^{12}$ These rates are the average rates for the 1990-2040 period.

Table 5.3. Fossil fuel price assumptions (1992 \$)

\begin{tabular}{lcc}
\hline Fuel & $\begin{array}{c}\text { 1992 Price } \\
(\$ / \mathrm{MBtu})\end{array}$ & $\begin{array}{c}\text { Real escalation rate } \\
\text { (\%/year) }\end{array}$ \\
\hline Coal & 1.45 & 1.0 \\
Natural gas & 2.33 & 2.2 \\
\hline
\end{tabular}




\subsubsection{Decommissioning}

The decommissioning cost for a $600-\mathrm{MW}(\mathrm{e})$ coal-fired unit is estimated to be $\$ 15$ million in $199^{\circ}$ dollars. Decommissioning costs are assumed to escalate at the rate of inflation. A sinking fund similar :o that described in Sect. 4.5 will be used to arcumulate the necessary funds during the operation of the plant.

\section{COST L: $:$ CULATION FOR A 600-MW(e) PULVERIZED COAL (PC) PLANT}

This section will discuss the calculation of the levelized cost for a single-unit $600 \mathrm{MW}(\mathrm{e})$ pulverized coal-fired plant starting commercial operation in the year 2010. Levelized costs for each cost component will be determined and then summed to obtain the total levelizec' busbar generation cost.

\section{Capital Cost}

As given in sect. 4.2, the levelized capital cost for a single-unit plant is found by multiplying the total capital cost by the fixed charge rate and dividing by the annual energy generation. The total capital cost for this plant is shown in Table 5.1 to be $\$ 1394$ S/kWe in 1992 dollars which is equivalent to a nominal dollar cost of \$2013 million for startup in 2010. The nominal dollar fixed charge rate for a coal plant with a 42 month construction schedule is $\mathbf{0 . 1 6 5 5}$. This fixed charge rate is determined using the methodology presented in the NECDB. ${ }^{5}$ This study assumes a constant annual energy generation at $80 \%$ capacity factor. For the $600-\mathrm{MW}(\mathrm{e})$ plant, this corresponds to generation of 4.2048 million MWh/yr.

Substituting in values, the equation from Sect. 4.2 becomes

$$
\begin{aligned}
\mathrm{LCC} & =\frac{(0.1655)(2013)}{4.2048} \\
& =79.2 \mathrm{mills} / \mathrm{k} \text { Whe }
\end{aligned}
$$


The constant doisar levelized cost is obtained by multiplying the nominal dollar cost by the nominal to constant cost factor from Table G.1

$$
\begin{aligned}
\mathrm{LCC}_{0} & =0.2451 \times \mathrm{LCC} \\
& =19.4 \mathrm{mills} / \mathrm{kWhe}
\end{aligned}
$$

The deflated nominal dollar cost is found by discounting the nominal dollar cost by the inflation between 1992 and 2010.

$$
\begin{aligned}
\operatorname{LCC}_{\mathrm{D}} & =(1.05)^{-18} \times 79.2 \\
& =(0.4155) \times 79.2 \\
& =32.9 \text { mills } / \mathrm{kWhe} .
\end{aligned}
$$

\subsection{O\&M Cost}

The present worth of the O\&M cost is given by the equation in Sect. 4.3 as

$$
P W O M=(1+i)^{L} \sum_{n=1}^{30} \frac{O M_{o, n}}{\left(1+d_{o}\right)^{n}}
$$

The annual O\&M cost is given in Table 5.2 as $\$ 38.1$ million. The real cost of money $\left(d_{0}\right)$ is 4.35\% and the PWOM for this single unit PC plant becomes

$$
\begin{aligned}
\text { PWOM } & =(1.05)^{18} \times 38.1 / \text { CRF }(4.35,30) \\
& =\frac{2.4066 \times 38.1}{0.06031} \\
& =\$ 1520 \text { million }
\end{aligned}
$$


The nominal dollar levelized cost is

$$
\begin{aligned}
\text { LCOM } & =\frac{\operatorname{CRF}(9.57,30) \times 1520}{4.2048} \\
& =\frac{(0.1023) \times 1520}{4.2048} \\
& =37.0 \mathrm{mills} / \mathrm{kWhe} .
\end{aligned}
$$

The constant dollar levelized cost is

$$
\operatorname{LCOM}_{0}=37.0 \times 0.2451=9.1 \mathrm{mills} / \mathrm{kWhe},
$$

and the deflated nominal dollar levelized cost is

$$
\mathrm{LCOM}_{D}=37.0 \times 0.4155=15.4 \mathrm{mills} / \mathrm{kWe}
$$

\subsection{Fuel Cost}

The basic procedure for obtaining the levelized fuel cost is described in Sect. 4.4. For a single unit plant, the present worth of the fuel costs is given by

$$
\text { PWFC }=\frac{(1+g)^{L} \times F C}{\operatorname{CRF}(Z, 30)}
$$

where

$\mathrm{g}$ = nominal rate of increase in coal price

$\mathrm{Z}$ = combined escalation, discount rate $=(1+d) /(1+g)-1$, where $d=$ nominal dollar discount rate

$\mathrm{FC}=$ annual cost of fuel in reference year.

Using a coal price of $\$ 1.45 / \mathrm{MBtu}(1992 \$)$, a plant heat rate of $9700 \mathrm{Btu} / \mathrm{kWh}$, and an annual generation of $4.2048 \times 10^{9} \mathrm{kWh}$,

$$
\begin{aligned}
\mathrm{FC} & =1.45 \times 9.7 \times 4.2048 \\
& =\$ 59.1 \mathrm{million} / \mathrm{yr}(\mathbf{1 9 9 2} \mathbf{}) .
\end{aligned}
$$


The price of coal is assumed to escalate at a real rate of $1 \%$ /yr (nominal rate $(\mathrm{g})=6.05 \% / \mathrm{yr}$ including 5\%/yr inflation rate), so

$$
Z=\frac{1.0957}{1.0605}-1=0.0332 \text { or } 3.32 \%
$$

Substituting for the present worth of the fuel costs,

$$
\begin{aligned}
\text { PWFC } & =\frac{(2.8787)(59.1)}{0.05315} \\
& =\$ 3201 \text { million }
\end{aligned}
$$

The nominal dollar levelized cost is

$$
\begin{aligned}
\text { LCFC } & =\frac{(0.1023)(3201)}{4.2048} \\
& =77.9 \text { mills } / \mathrm{kWhe} .
\end{aligned}
$$

The constant dollar levelized fuel cost is

$$
\mathrm{LCFC}_{0}=(0.2451)(77.9)=19.1 \mathrm{mills} / \mathrm{kWhe},
$$

and the deflated nominal dollar levelized fuel cost is

$$
\mathrm{LCFC}_{\mathrm{D}}=(0.4155)(77.9)=32.4 \text { mills } / \mathrm{kWhe}
$$

\section{Decommissioning Cost}

Following the NECDB, a $600 \mathrm{MW}(\mathrm{e})$ coal-fired unit will have a decommissioning (dismantalment) cost of $\$ 15$ million. Substituting into the equation in Sect. 4.5 , the present value of the decommissioning cost becomes 


$$
\begin{aligned}
\text { PWDC } & =\frac{(15)(2.407)(0.01059)}{(3.5873)(0.006593)} \\
& =\$ 16.2 \text { million } .
\end{aligned}
$$

The nominal dollar levelized cost is

$$
\mathrm{LCDC}=\frac{(0.1023)(16.2)}{4.2048}=0.39 \text { mills } / \mathrm{kWhe}
$$

The constant dollar levelized cost is

$$
\mathrm{LCDC}_{\mathrm{o}}=(0.2451)(0.39)=0.10 \mathrm{mills} / \mathrm{kWhe} \text {. }
$$

The deflated nominal dollar cost is

$$
\mathrm{LCDC}_{\mathrm{D}}=(0.4155)(0.39)=0.16 \text { mills } / \mathrm{kWhe} \text {. }
$$

\subsection{Busbar Costs}

The levelized busbar costs are the sum of the component costs

LC $=194.5$ mills $/ \mathrm{kWhe}$ (nominal dollars)

$L_{0}=47.7$ mills/kWhe (constant 1992\$)

$\mathrm{LC}_{\mathrm{D}}=\mathbf{8 0 . 9}$ mills $/ \mathrm{kWhe}$ (deflated nominal dollars).

\section{COST CALCULATION FOR TWO UNIT 500 MW(e) COMBINED CYCLE COMBUSTION TURBINE PLANT}

This section will discuss the calculation of the levelized cost for a 500-W(e) Combined cycle combustion turbine plant with toth units starting commercial operation in the year 2010. Levelized costs for each ccist component will be determined and then summed to obtain the total busbar generation levelized cost. 


\subsubsection{Capital Cost}

The total capital cost for this plant was shown in Table 5.1 to be $565 \mathrm{~S} / \mathrm{kWe}$ in 1992 dollars. This is equivalent to a nominal dollar cost of $\$ 679$ million for startup in 2010.

The nominal dollar fixed charge rate for this plant is 0.1646 using the methodology in the NECDB. ${ }^{5}$ The annual energy generation for this plant at $80 \%$ capacity factor is $\mathbf{3 . 5 0 4}$ million MWh/year.

Substituting in the values, the equation from Sect. 4.2 becomes

$$
\begin{aligned}
\mathrm{LCC} & =\frac{(0.1646)(679)}{3.504} \\
\mathrm{LCC} & =31.9 \mathrm{mills} / \mathrm{kWhe} .
\end{aligned}
$$

The constant dollar levelized cost is obtained by multiplying the nominal dollar cost by the constant to nominal cost factor from Table G.1.

$$
\begin{aligned}
\mathrm{LCC}_{0} & =0.2451 \times \mathrm{LCC} \\
& =7.8 \mathrm{mills} / \mathrm{kWhe} .
\end{aligned}
$$

The deflated nominal dollar cost is found by discounting the nominal dollar cost by the inflation between 1992 and 2010

$$
\begin{aligned}
\mathrm{LCC}_{\mathrm{D}} & =(1.05)^{-18} \times 31.9 \\
& =13.3 \text { mills } / \mathrm{k} \text { Whe }
\end{aligned}
$$

\subsection{O\&M Cost}

The present worth of the O\&M cost is

$$
P W O M=(1+i)^{L} \sum_{n} \frac{O M_{0,0}}{\left(1+d_{0}\right)^{1}}
$$


The annual O\&M cost is given in Table 5.2 as $\$ 7.8$ million. The present worth of the O\&M cost is:

$$
\begin{aligned}
\text { PWOM } & =(1.05)^{18} \frac{7.8}{0.06031} \\
& =\$ 311 \text { million }
\end{aligned}
$$

The nominal dollar levelized cost is

$$
\begin{aligned}
\text { LCOM } & =\frac{\operatorname{CRF}(9.57,30) \times(311)}{3.504} \\
& =\frac{(0.1023) \times(311)}{3.504} \\
& =9.1 \mathrm{mills} / \mathrm{kWhe} .
\end{aligned}
$$

In constant dollars:

$$
\mathrm{LCOM}_{0}=(0.2451)(9.1)=2.2 \text { mills } / \mathrm{kWhe} \text {. }
$$

In deflated nominal dollars:

$$
\operatorname{LCOM}_{\mathrm{D}}=(0.4155)(9.1)=3.8 \text { mills } / \mathrm{kWhe} \text {. }
$$

\subsubsection{Fuel Cost}

Using the reference natural gas price of \$2.33/MBtu (1992\$), a CCCT plant heat rate of 7514 , and the annual generation of $3.504 \times 10^{9} \mathrm{kWh}$, the annual fuel cost (FC) in the reference year is

$$
\begin{aligned}
F C & =(2.33)(7.514)(3.504) \\
& =\$ 61.3 \text { million } .
\end{aligned}
$$


The price of natural gas is assumed to escalate at $2.2 \% / y r$ above inflation $(7.31 \% / y r$ nominal rate), so the nominal price increase prior to startup is,

$$
(1.0731)^{18}=3.561
$$

The effective discount factor for the capital recovery factor is,

$$
Z=\frac{1.0957}{1.0731}-1=0.0211 \text { or } 2.11 \%
$$

and

$$
\operatorname{CRF}(2.11,30)=0.04530
$$

Substituting for the present Worth of the fuel costs,

$$
\begin{aligned}
\text { PWFC } & =\frac{(3.561)(61.3)}{0.04530} \\
& =\$ 4,418 \text { million }
\end{aligned}
$$

The nominal dollar levelized fuel cost is

$$
\begin{gathered}
\text { LCFC }=\frac{(0.1023)(4418)}{3.504} \\
=140.7 \text { mills } / \mathrm{kWhe} .
\end{gathered}
$$

The constant dollar levelized cost is

$$
\text { LCFC }_{o}=(0.2451)(140.7)=34.5 \text { mills } / \mathrm{kWhe} \text {. }
$$


The deflated nominal dollar fuel cost is

$$
\mathrm{LCFC}_{\mathrm{D}}=(0.4155)(140.7)=58.4 \text { mills } / \mathrm{kWhe} \text {. }
$$

\subsubsection{Decommissioning Cost}

The decommissioning cost for the CCCT is assumed to be negligable.

\subsubsection{Busbar Cost}

The levelized busbar cost is the sum of the component costs,

LC $=181.7$ Mills $/ \mathrm{kWhe}$ (nominal dollars)

$L_{0}=44.5$ mills $/ \mathrm{kWhe}$ (constant 1992 \$)

$\mathrm{LC}_{\mathrm{D}}=75.5$ mills/KWhe (deflated nominal dollars).

\subsection{COST CALCULATION FOR A TWO UNIT 600-MWe PC PLANT}

This section will discuss the calculation of the levelized cost for a plant with two $600 \mathrm{MW}(\mathrm{e}) \mathrm{PC}$ units where the second unit follows the first on line by one year. The first unit startup is in 2010.

\subsubsection{Capital Cost}

The 1992 dollar total capital costs are shown in Table 5.1. The total capitalized cost for the first unit in nominal dollars at startup in 2010 is.

$$
\begin{gathered}
\left(600 \times 10^{3}\right)(1394)(1.05)^{18} \\
=\$ 2,013 \text { million }
\end{gathered}
$$

The second unit, starting up in 2011 will have a nominal dollar cost of

$$
\left(600 \times 10^{3}\right)(1180)(1.05)^{19}
$$

$=\$ 1,789$ million. 
The fixed charge rate is 0.1655 and the annual energy production, per unit at $80 \%$ capacity factor is 4.2048 million MWh.

$$
\begin{gathered}
\text { LCC }=\frac{(0.1655)\left[2013+1789(1.0957)^{-1}\right]}{(4.2048)\left[1+(1.0957)^{-1}\right]} \\
=75.0 \mathrm{mills} / \mathrm{kWh} .
\end{gathered}
$$

The constant dollar cost is

$$
\mathrm{LCC}_{\mathrm{o}}=(0.2451)(75.0)=18.4 \mathrm{mills} / \mathrm{kWhe}
$$

and the deflated nominal dollar cost is

$$
\operatorname{LCC}_{\mathrm{D}}=(0.4155)(75.0)=31.2 \mathrm{mills} / \mathrm{kWhe}
$$

\subsubsection{O\&M Cost}

The annual O\&M cost for year 1 and $31(2010,2041)$ in 1992 dollars is \$38.1 million and $\$ 70.8$ million for years 2 through 30 . The present worth (to plant startup) is $\$ 2,818$ million.

The nominal dollar levelized cost is

$$
\mathrm{LCOM}=\frac{(0.1023)(2818)}{4.2048\left[1+(1.0957)^{-1}\right]}=35.8 \mathrm{mills} / \mathrm{kWhe}
$$

The constant dollar levelized cost is obtained by multiplying the nominal dollar cost by the constant to nominal cost factor from Table G.1. (Note that this factor is different for the 2-unit plant than for a single unit plant.)

$$
\operatorname{LCOM}_{o}=(0.2394)(35.8)=8.6 \text { mills } / \mathrm{kWe} \text {. }
$$


In deflated nominal dollars

$$
\operatorname{LCOM}_{D}=(0.4155)(35.8)=14.9 \text { mills } / \mathrm{kWhe} \text {. }
$$

\subsubsection{Fuel Cost}

Using the reference coal price of $\$ 1.45 / \mathrm{MBtu}(1992)$, plant heat rate of $9700 \mathrm{Btu} / \mathrm{kWh}$ and an annual generation of $4.2048 \times 10^{9} \mathrm{kWh}$ per unit, the annual cost of fuel (FC) in the reference year is $\$ 59.1$ million for each unit. The present worth to plant startup of the fuel cost, in nominal dollars is given by

$$
\mathrm{PWFC}=\frac{(1+\mathrm{g})^{\mathrm{L}} \times \mathrm{FC} \times \sum_{\mathrm{j}} 1 /(1+\mathrm{Z})^{\mathrm{j}-1 \mathrm{l}}}{\mathrm{CRF}(\mathrm{Z}, 30)}
$$

where the final term in the numerator accounts for the timing delay of the multiple units. Substituting,

$$
\begin{aligned}
\text { PWFC } & =\frac{(2.8787)(59.1)(1.9679)}{0.05315} \\
& =6,299 \text { million. }
\end{aligned}
$$

The nominal dollar levelized fuel cost is

$$
\begin{gathered}
\text { LCFC }=\frac{(0.1023)(6.299)}{8.0423} \\
=80.1 \text { mills } / \mathrm{kWhe} .
\end{gathered}
$$

The constant dollar levelized cost is

$$
\mathrm{LCFC}_{\mathrm{o}}=(0.2394)(80.1)=19.2 \text { mills } / \mathrm{kWhe} \text {. }
$$

The deflated nominal dollar fuel cost is

$$
\operatorname{LCFC}_{\mathrm{D}}=(0.4155)(80.1)=33.3 \mathrm{mills} / \mathrm{kWhe}
$$

\subsubsection{Decommissioning Cost}

The decommissioning cost was calculated previously in Sect. 5.2.4.

The nominal dollar levelized cost $=0.39$ mills $/ \mathrm{kWhe}$. 
The constant, $1992 \$$ levelized cost $=0.10 \mathrm{mill} / \mathrm{kWhe}$.

The deflated nominal dollars levelized cost $=0.16 \mathrm{mills} / \mathrm{kWhe}$.

\subsubsection{Busbar Costs}

The levelized busbar costs are the sum of the cost components. For the 2-unit $600 \mathrm{MW}(\mathrm{e})$ PC Plant these are

$$
\begin{aligned}
& \mathrm{LC}=191.3 \text { mills } / \mathrm{kWhe} \text { (nominal dollars) } \\
& \mathrm{LC}_{\mathrm{o}}=46.3 \text { mills } / \mathrm{k} \text { Whe (constant } 1992 \text { dollars) } \\
& \mathrm{LC}_{\mathrm{D}}=79.6 \text { mills } / \mathrm{kWhe} \text { (deflated nominal dollars). }
\end{aligned}
$$




\section{REFERENCES}

1. C. R. Hudson II, Cost Estimate Guidelines for Advanced Nuclear Power Technologies, ORNL/TM-10071/R1, Martin Marietta Energy Systems, Inc., Oak Ridge National Laboratory, July 1987.

2. J. G. Delene and C. R. Hudson II, Cost Estimate Guidelines for Advanced Nuclear Power Technologies, ORNL/TM-10071/R2, Martin Marietta Energy Systems, Inc., Oak Ridge National Laboratory, March 1990.

3. Technical Reference Book for the Energy Economic Data Base Program EEDB Phase IX (1987), DOE/NE-0092, U.S. Department of Energy, Office of Nuclear Energy, September 1988.

4. Guide for the Economic Evaluation of Nuclear Reactor Plant Designs, NUS-531, prepared for U.S. Atomic Energy Commission by NUS Corporation (January 1969).

5. Nuclear Energy Cost Data Base-A Reference Data Base for Nuclear and Coal-Fired Power Plant Generation Cost Analysis, DOE/NE-0095, September 1988.

6. Bechtel National, Inc. letter, D. A. Dilling to Jerry Delene, BNI/GCRA: 93-663, January 22, 1993.

7. National Economic Trends, Prepared by The Federal Reserve Bank of St. Louis, April 1992 and previous issues.

8. The Handy-Whitman Index of Public Utility Construction Costs, Whitman, Requardt and Associates, Baltimore, Maryland 21202.

9. J. J. Coen and J. G. Delene, User Instructions for Levelized Power Generation Cost Codes Using an IBM-Type-PC, ORNL/TM-10997, Martin Marietta Energy Systems, Inc., Oak Ridge National Laboratory, January 1989.

10. J. G. Delene and O. W. Hermann, REFC0-83 User's Manual, ORNL/TM-9186, Martin Marietta Energy Systems, Inc., Oak Ridge Natl. Lab., June 1984.

11. Advanced Design Nuclear Power Plants: Competitive, Economical Electricity, U.S. Council for Energy Awareness, June 1992.

12. Supplement to the Annual Energy Outlook 1992, Energy Information Administration, USDOE, DOE/EIA-0554(92), February 1992.

13. MHTGR Cost Estimating Groundrules and Procedures, Gas-Cooled Reactor Associates, HP10701 (to be published). 


\section{ABBREVIATIONS AND ACRONYMS}

$A E \quad$ architect engineer

AFUDC allowance for funds used during construction

ALMR advanced liquid metal reactor

ALWR advanced light water reactor

BOP balance of plant

CCCT combined cycle combustion turbine

$\mathrm{CM}$ construction manager

CM chrome moly steel

CONCEPT name of capital cost computer code

CRF capital recovery factor

CS carbon steel

CY cubic yards

DOE Department of Energy

DPC direct payroll related costs

EEDB Energy Economic Data Base

EIA DOE Energy Information Administration

EPRI Electric Power Research Institute

FBC Fluidized Bed Combustion

FCR fixed charge rate

FOAK First-of-a-Kind

FSAR final safety analysis report

G\&A General and Administrative costs

HM heavy metal

IDC interest during construction

IPP Independent Power Producer

LB pounds

LF linear feet

LWR Light Water Reactor

MHTGR Modular High Temperature Gas-cooled Reactor 


\begin{tabular}{|c|c|}
\hline MRB & materials reviews board \\
\hline NE & Nuclear Energy \\
\hline NNS & non-nuclear-safety class \\
\hline NOAK & Nth-of-a-Kind \\
\hline NRC & Nuclear Regulatory Commission \\
\hline NSSS & Nuclear Steam Supply System \\
\hline O\&M & operation and maintenance \\
\hline OMCOST & name of operation and maintenance cost computer code \\
\hline PC & personal computer or pulverized coal \\
\hline P\&ID & piping and instrumentation diagram \\
\hline PSAR & preliminary safety analysis report \\
\hline PWR & pressurized water reactor \\
\hline $\mathrm{Q} / \mathrm{C}$ & quality control \\
\hline Q/A & $\because$ :'ity assurance \\
\hline R\&D & Research and Development \\
\hline REFCO & name ố nuclear fuel cycle cost code \\
\hline $\mathrm{RCM}$ & Reliability Centered Maintenance \\
\hline $\mathbf{R M}$ & reactor manufacturer \\
\hline SAR & safety analysis report \\
\hline SC & safety class \\
\hline SDD & system design description \\
\hline SF & square feet \\
\hline SFF & sinking fund factor \\
\hline SS & stainless steel \\
\hline TN & tons \\
\hline
\end{tabular}

USCEA U.S. Council for Energy Awareness 


\title{
LIST OF SYMBOLS
}

\author{
$\mathrm{CAP}_{\mathrm{j}} \quad$ capital cost (nominal dollars) of block $\mathrm{j}$ \\ $\mathrm{C}_{\mathrm{j}} \quad$ cash flow during period $\mathrm{j}$ \\ CNCF factor for converting nominal dollar levelized costs to constant dollar levelized \\ costs \\ $\operatorname{CRF}(a, b)$ capital recovery factor at rate, $a$, and period, $b$ \\ d nominal dollar discount rate \\ $\mathrm{DC}_{\mathrm{o}}$ decommissioning cost in reference years dollars \\ $d_{0} \quad$ constant dollar discount rate \\ $\mathrm{E}$ annual energy generation \\ FC fuel costs \\ FCR nominal dollar fixed charge rate \\ FCR $\quad$ constant dollar fixed charge rate \\ g escalation rate/year \\ i inflation rate, /year \\ IDC interest during construction in nominal dollars \\ IDC interest during construction in constant dollars \\ J total number of periods or blocks \\ j incex denoting period or block of capacity \\ L years between reference year and year of commercial operation \\ LC levelized cost in nominal dollars \\ $\mathrm{LC}_{\mathrm{D}} \quad$ levelized cost in deflated nominal dollars \\ LC levelized cost in constant dollars \\ LCC levelized cost of capital (nominal dollars) \\ LCDC levelized cost of decommissioning (nominal dollars) \\ LCFC levelized fuel cycle cost (nominal dollars) \\ LCOM levelized O\&M cost (nominal dollars) \\ n period index relative to time of commercial operation \\ $\mathrm{OM}_{\mathrm{aj}} \quad$ O\&M costs for block $\mathrm{j}$ in period $n$ \\ $\mathrm{OM}_{\mathrm{a}} \quad$ O\&M costs in reference year dollars in period $n$
}


P block thermal power

PWDC present worth of decommissioning cost

PWFC present worth of fuel cycle costs

PWOM present worth of O\&M costs

PWR pressurized water reactor

SFF $(a, b)$ sinking fund factor at rate, $a$, for period, $b$

$t_{1} \quad$ time first block put in operation

TCC Total capital cost in nominal dollars

$\mathrm{TCC}_{\mathrm{o}}$ total capital cost in constant dollars

$t_{j} \quad$ date at beginning of period $j$ or date block $j$ starts operation

to reference date (year given in sect. 2.2)

$t_{\text {op }} \quad$ year of commercial operation

$X \quad$ average cost of money in nominal dollars

$X_{0} \quad$ average cost of money in constant dollars

$\mathrm{Z}$ combined escalation/discount rate 
Appendix A

EEDB CODE OF ACCOUNTS FOR ADVANCED LIQUID-METAL REACTOR (ALMR) CONCEPT 


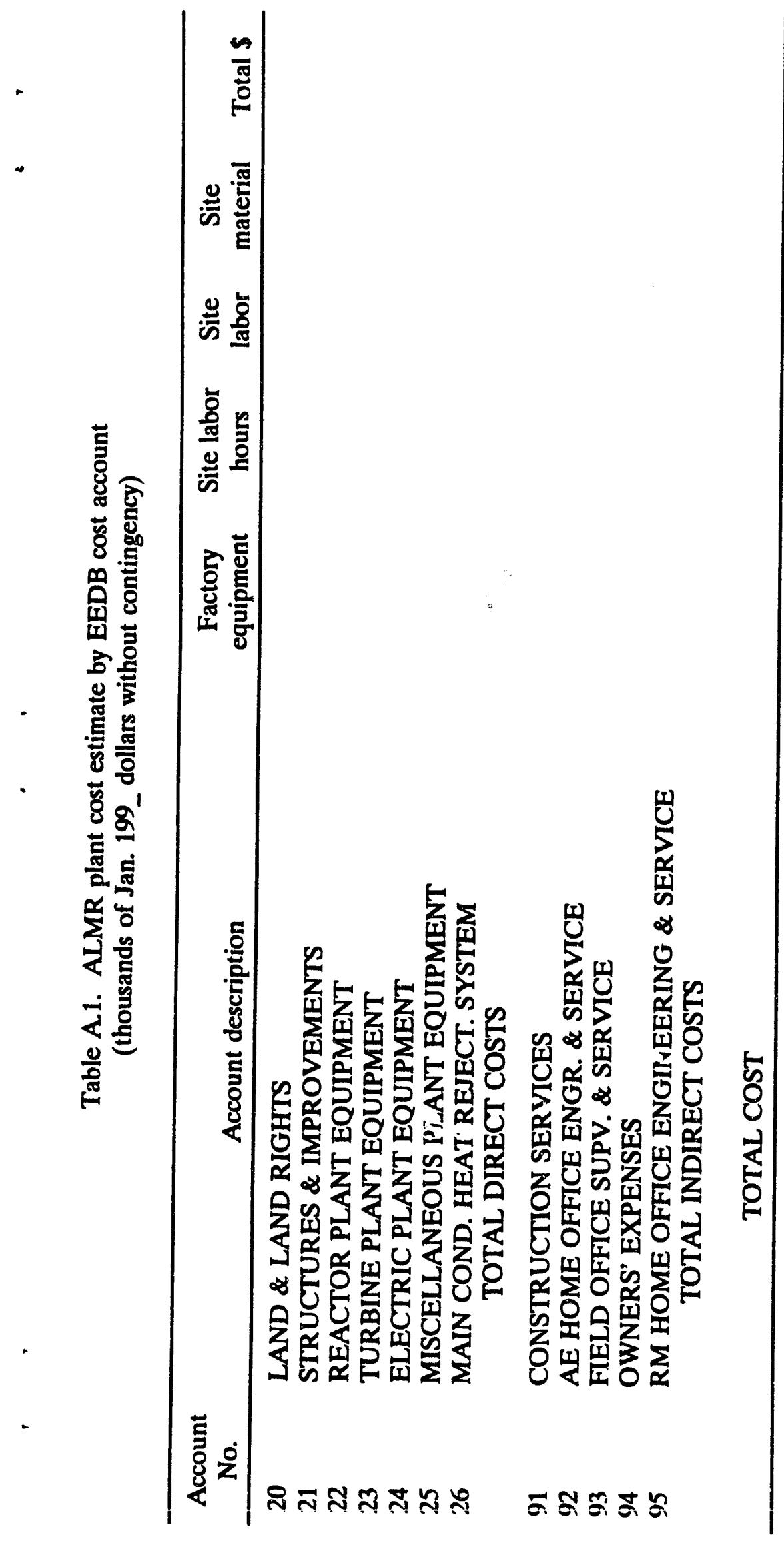




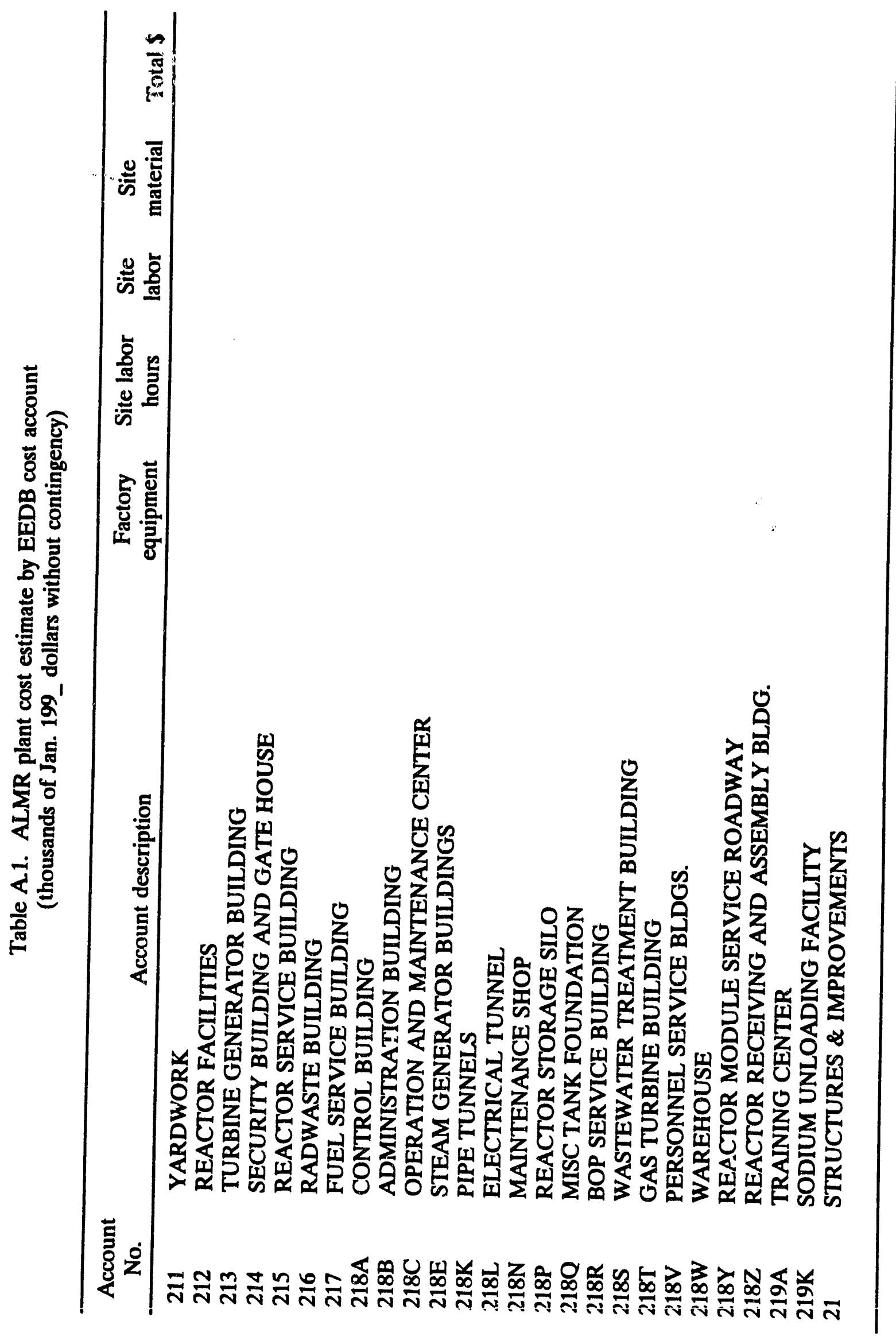




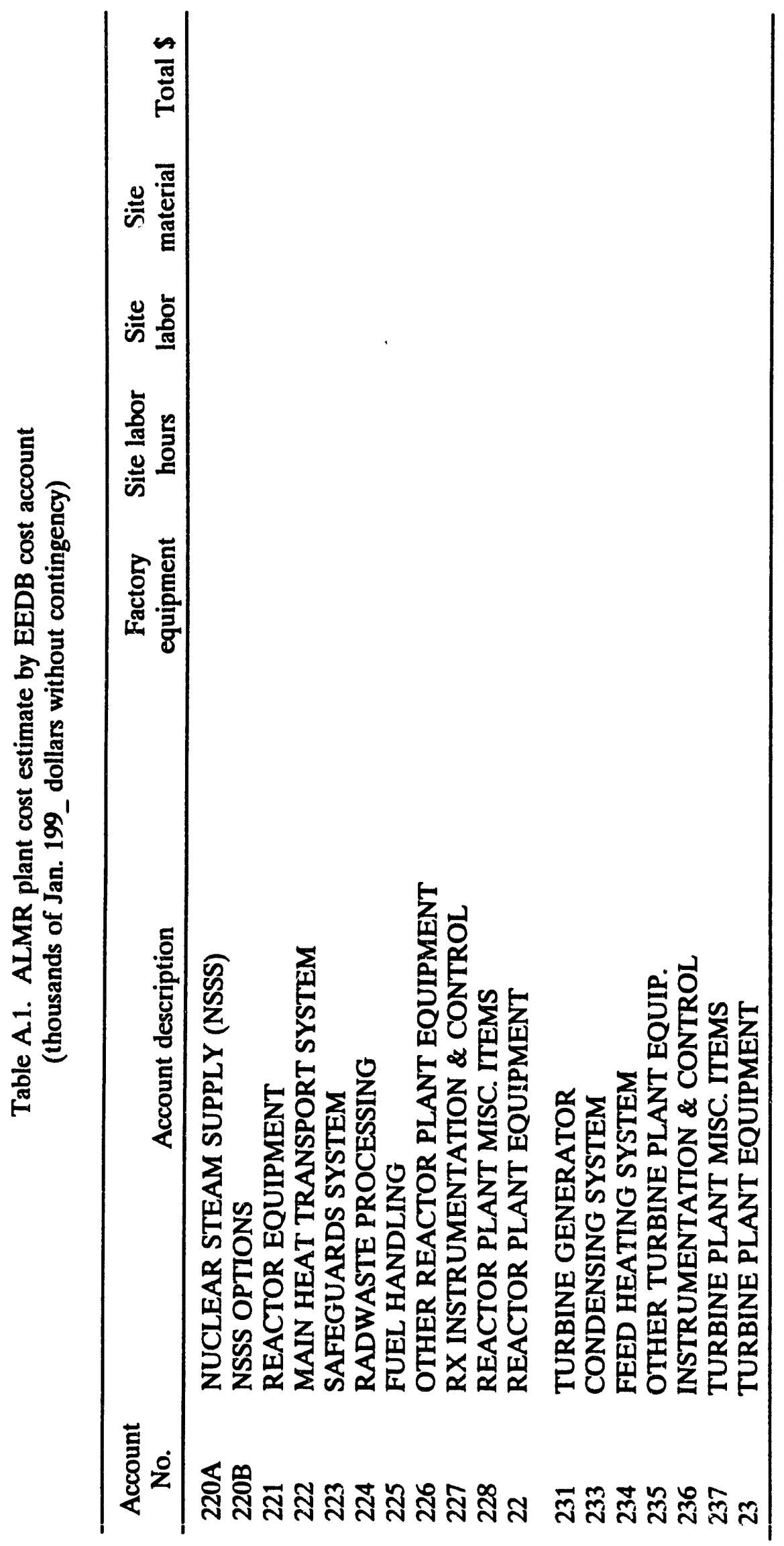




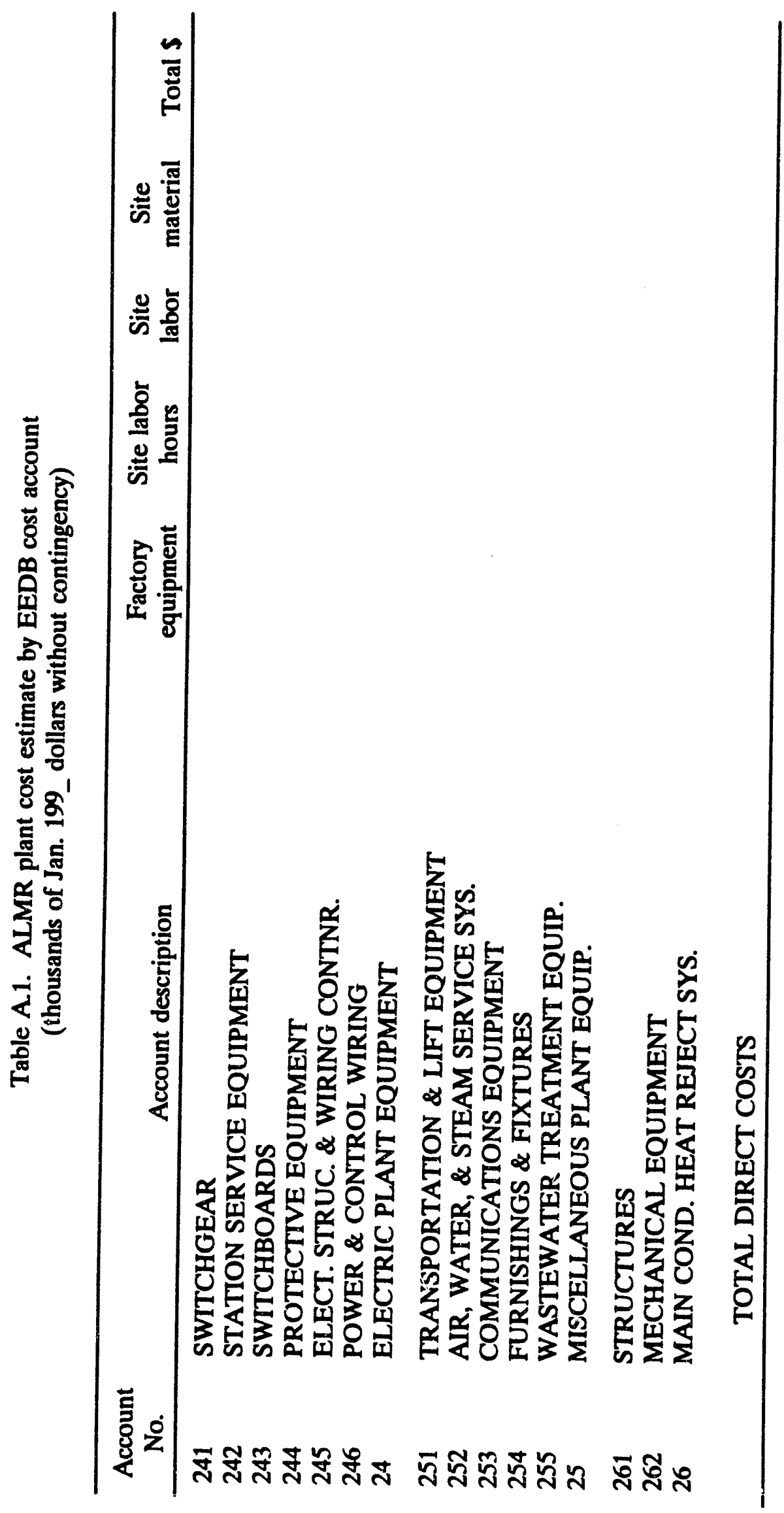




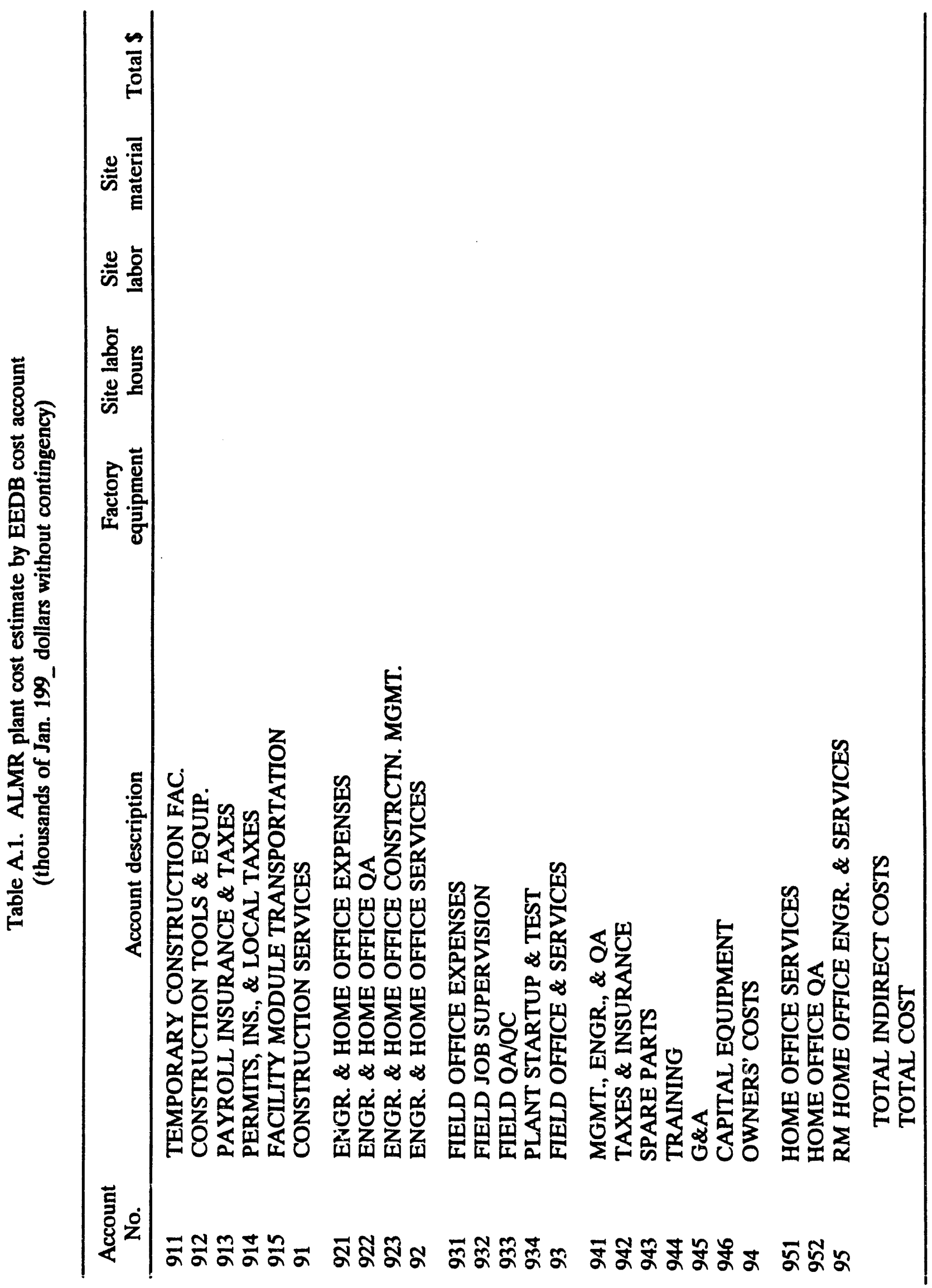




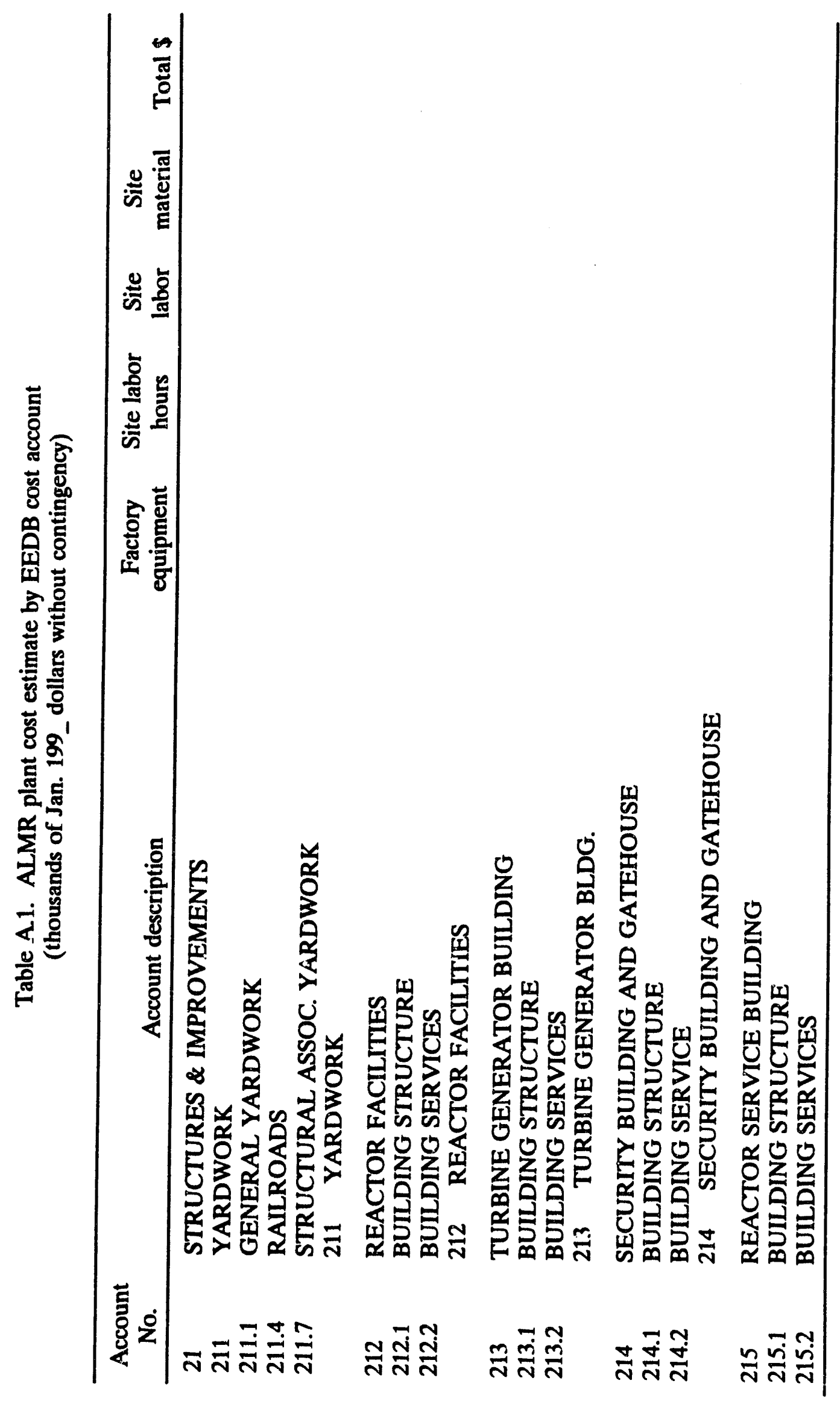




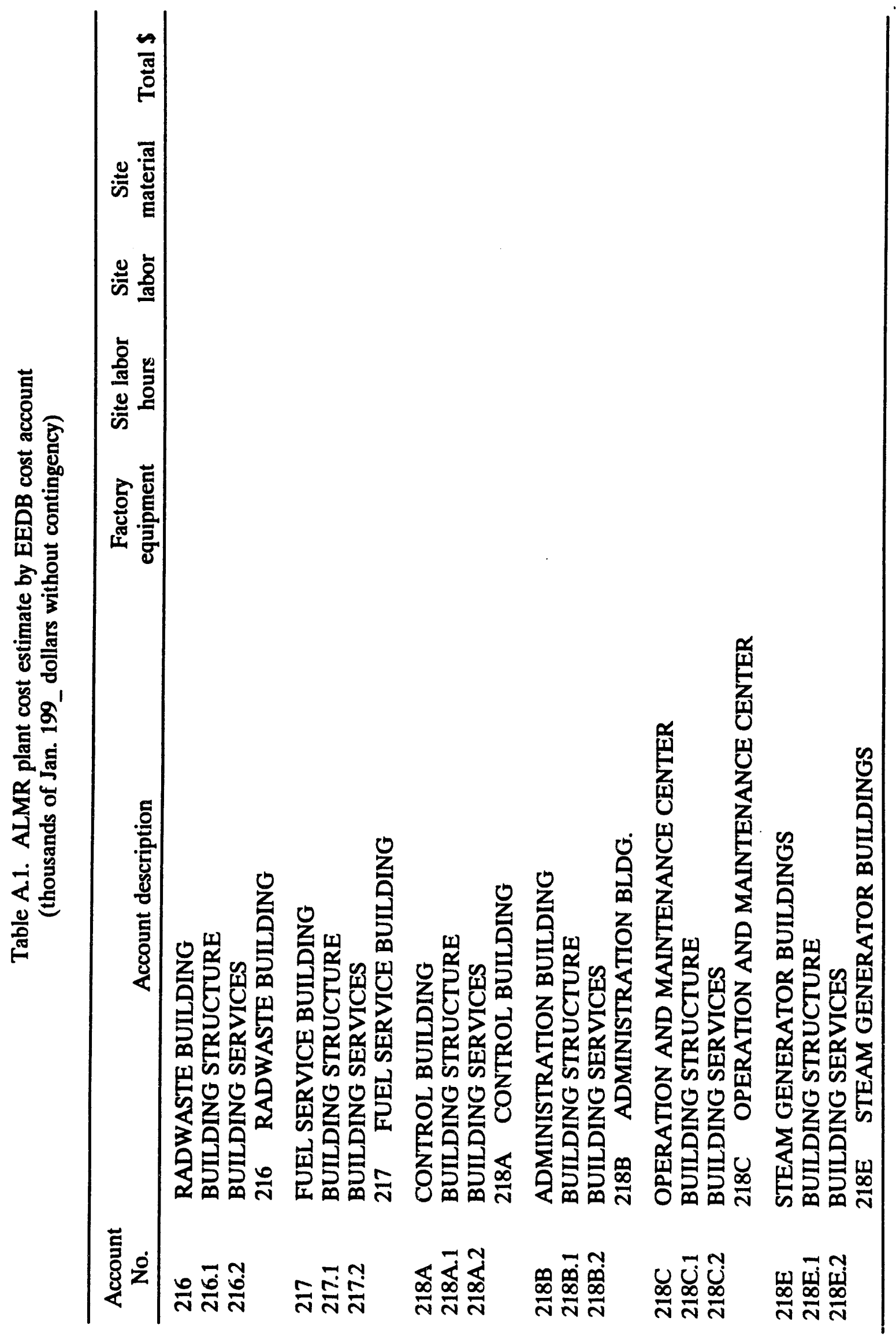




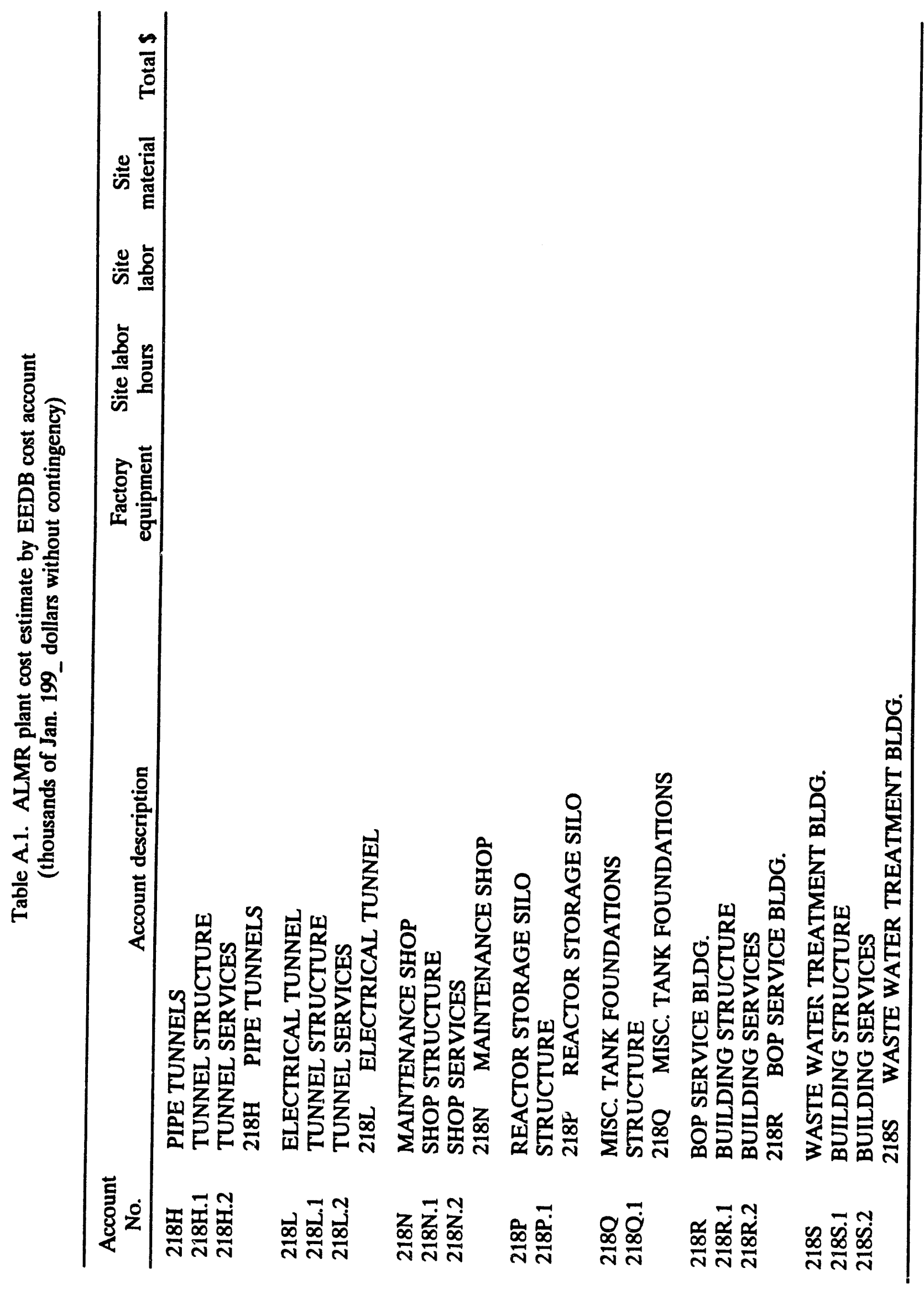




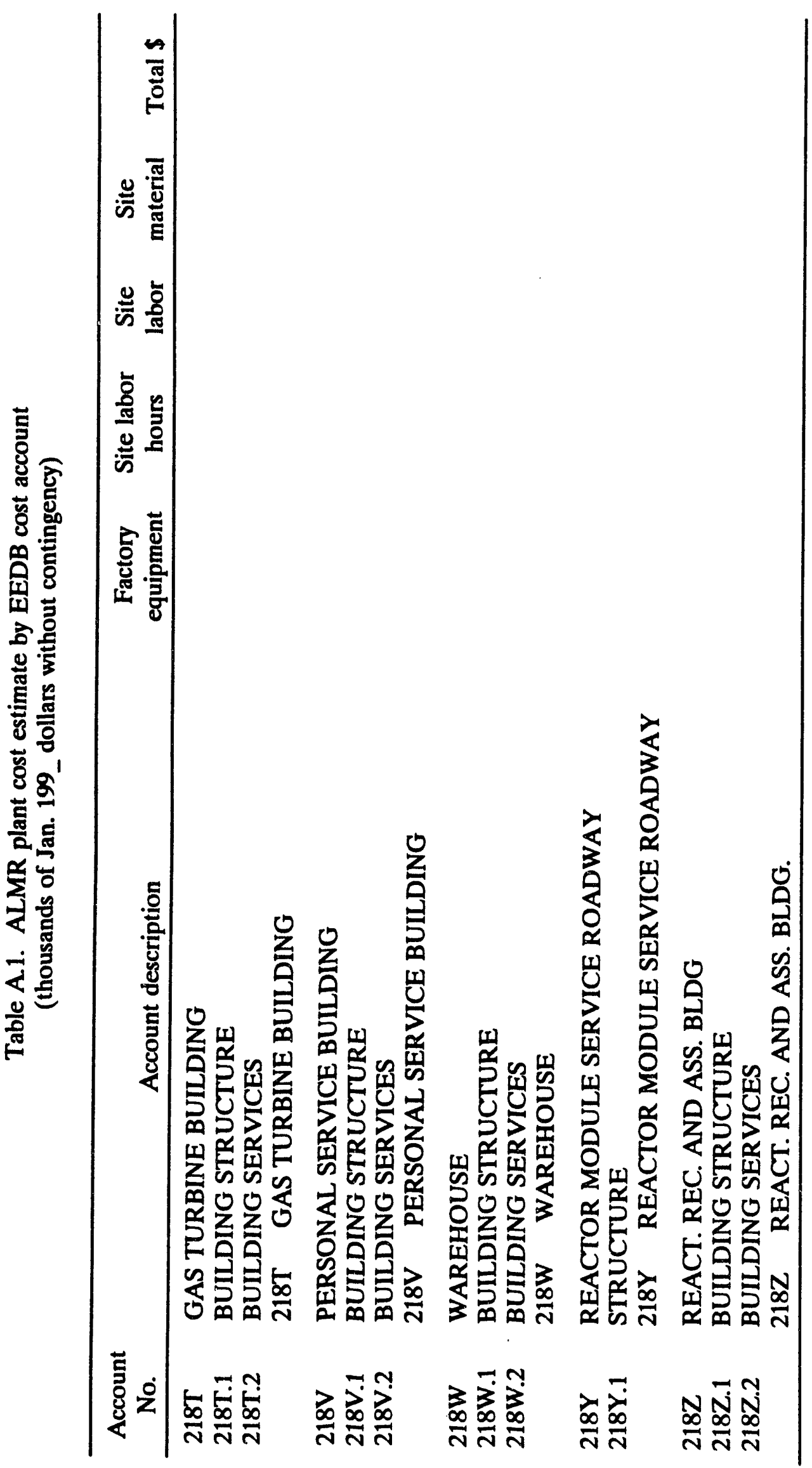




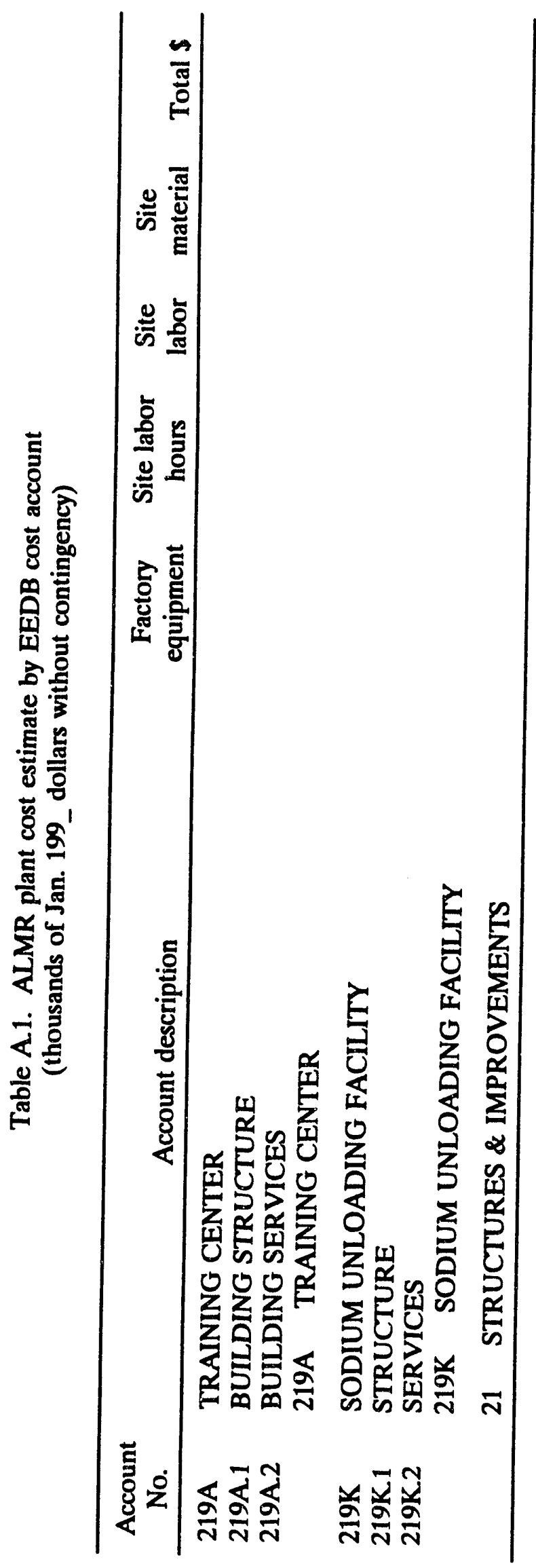




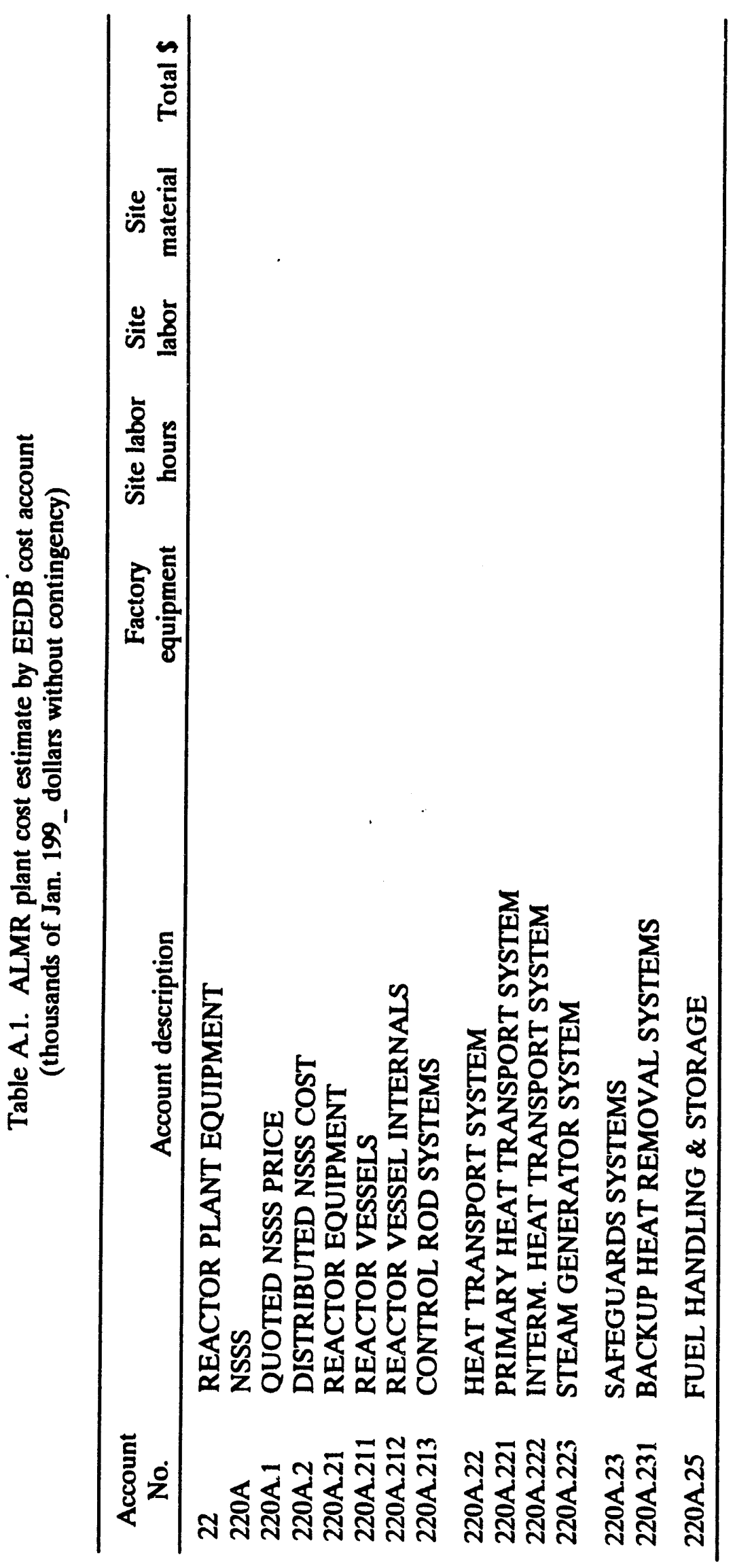




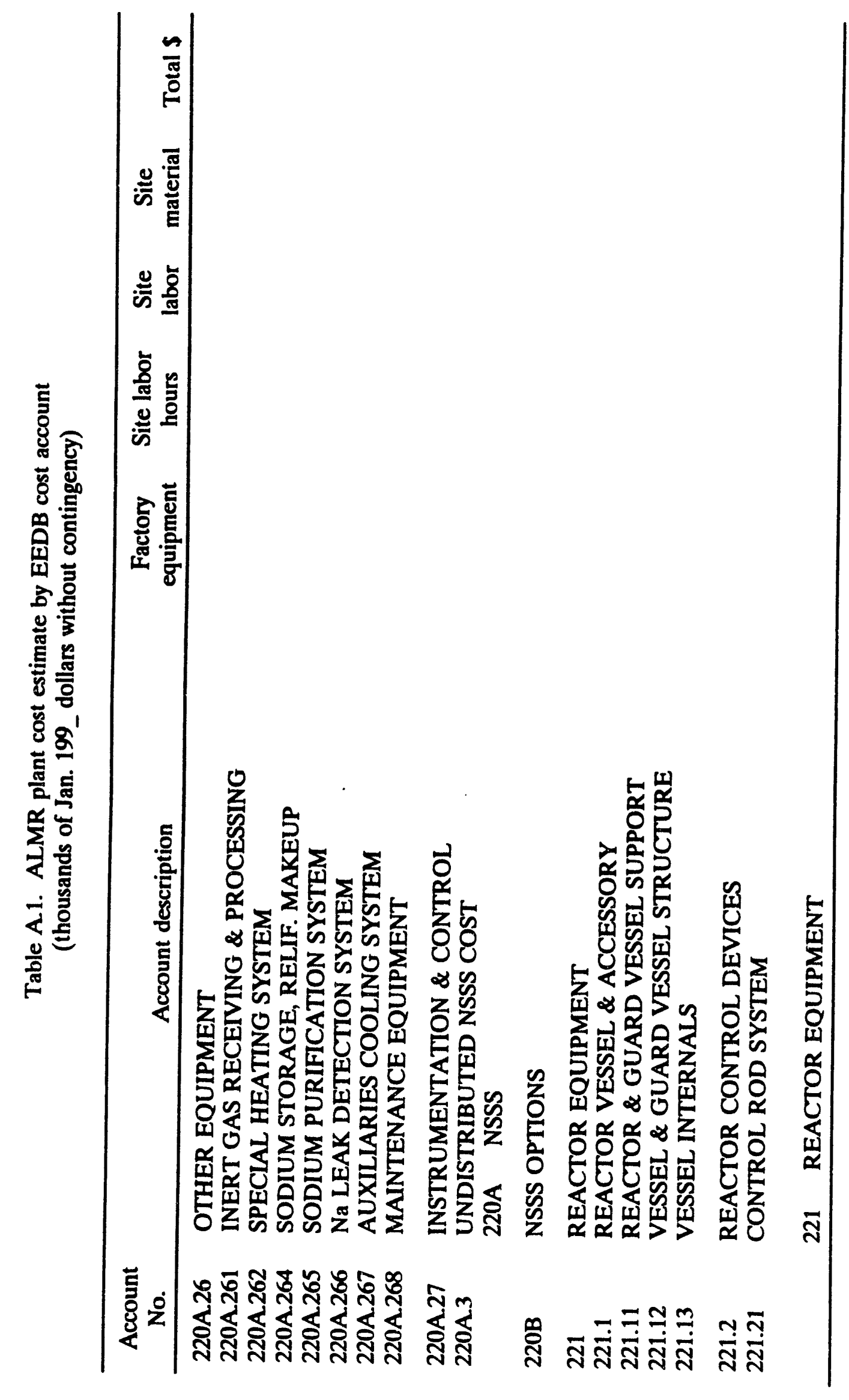




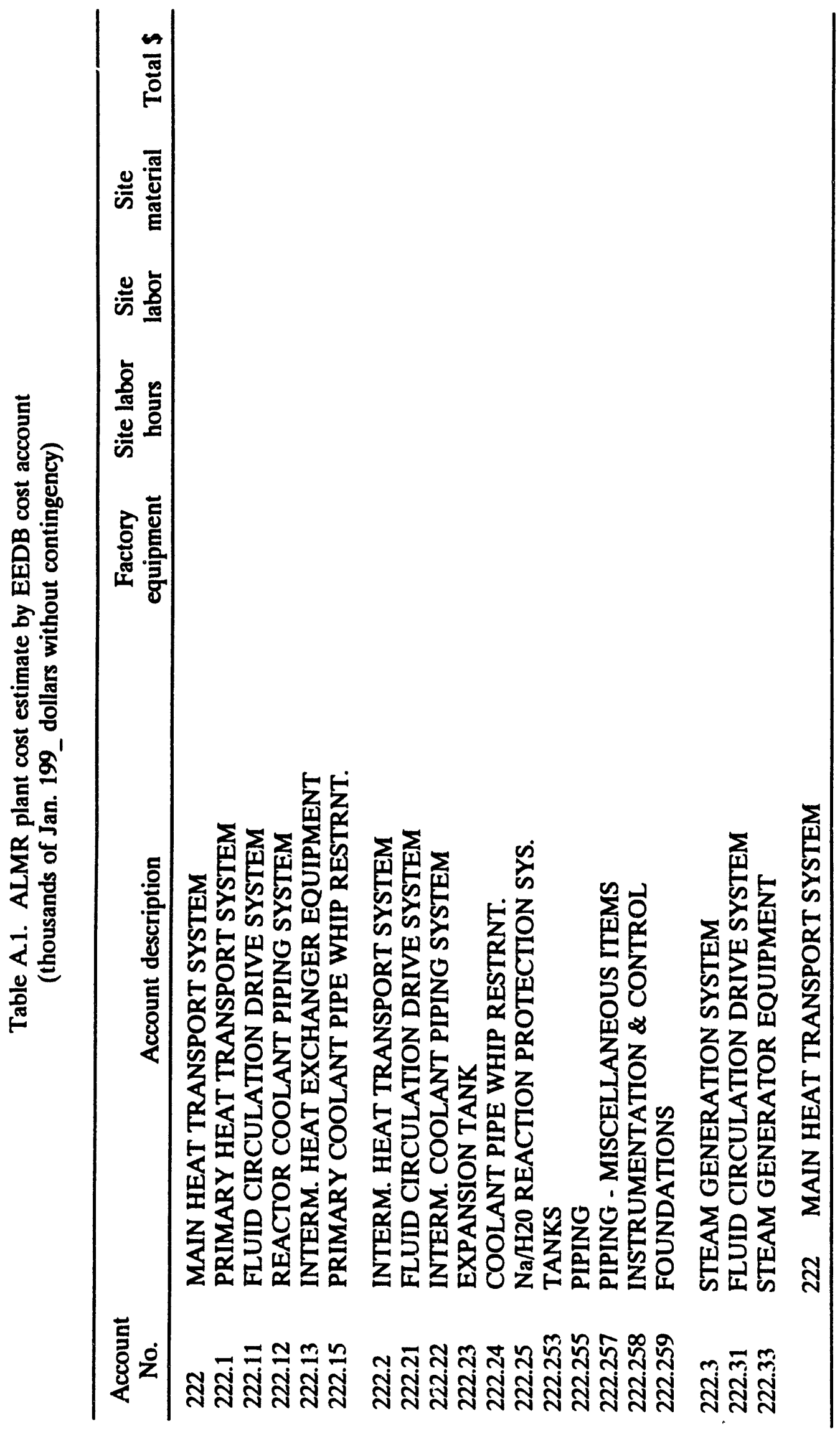




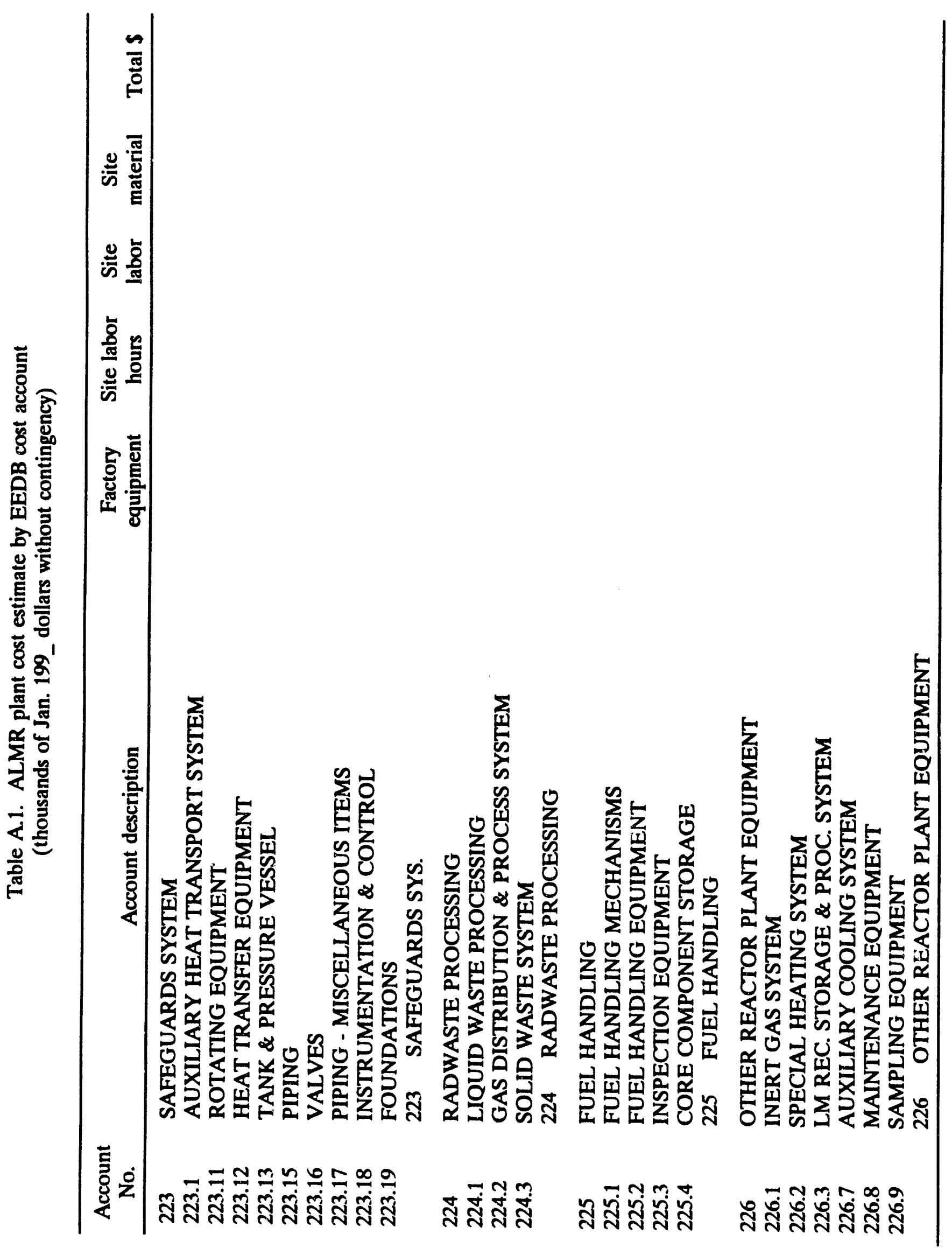




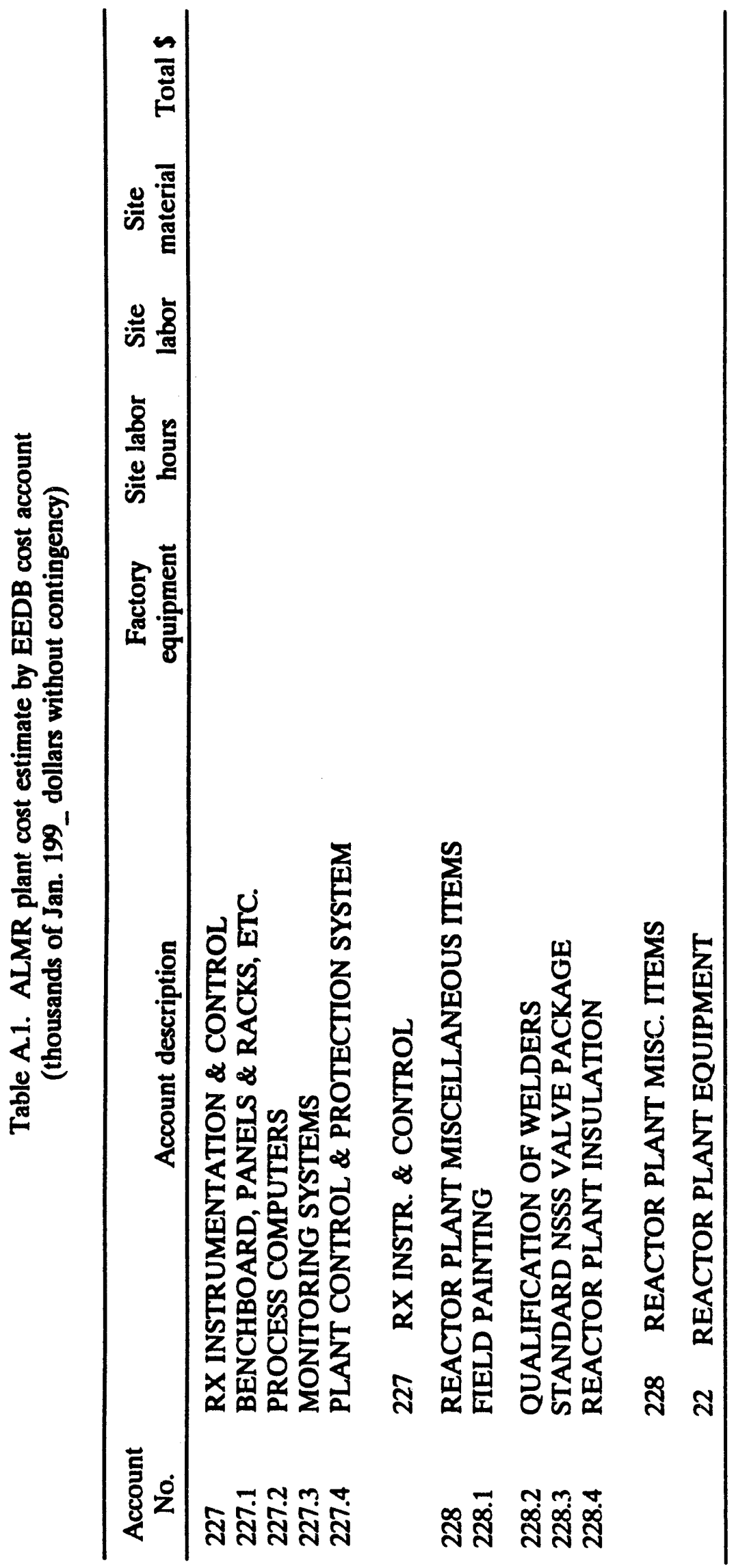




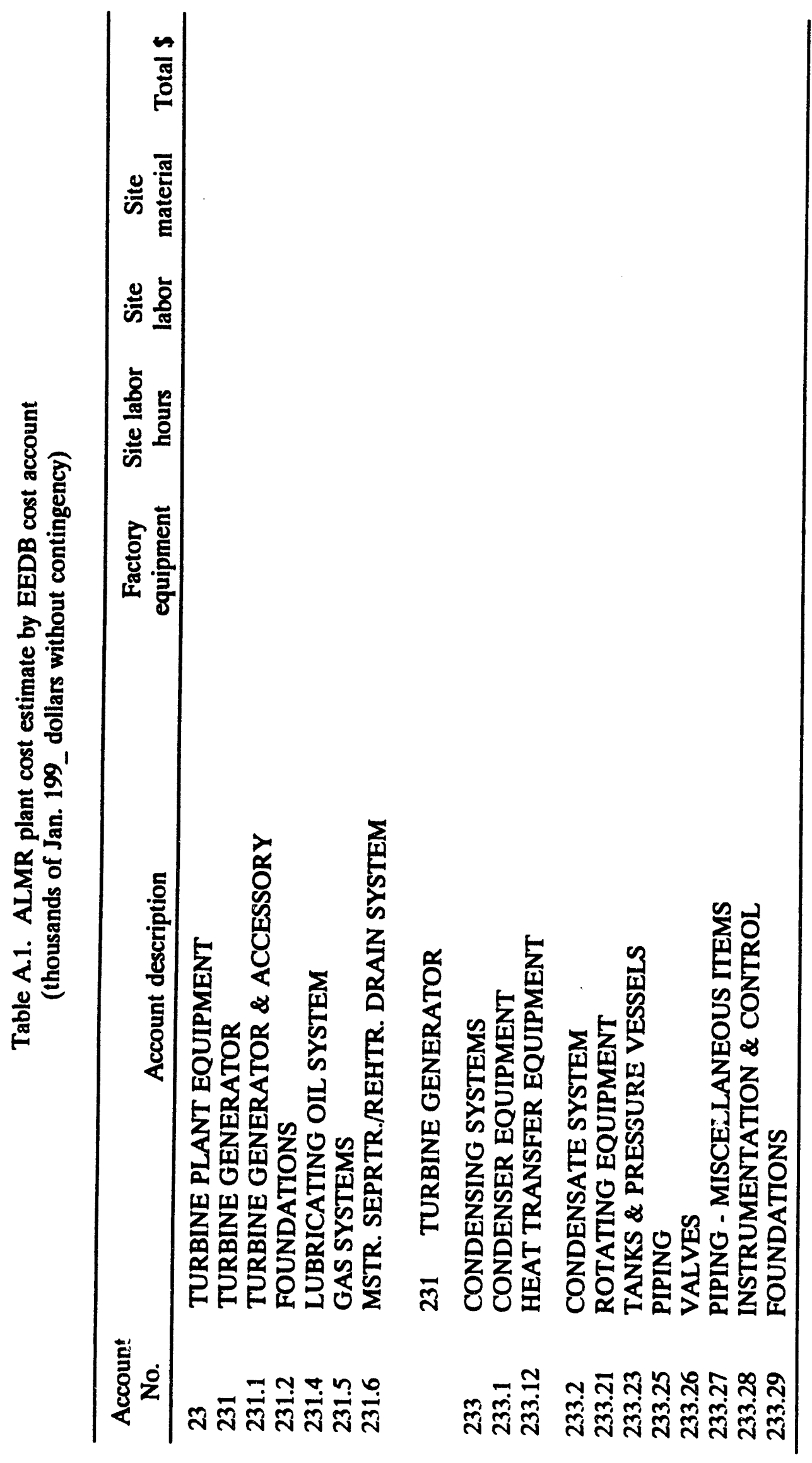




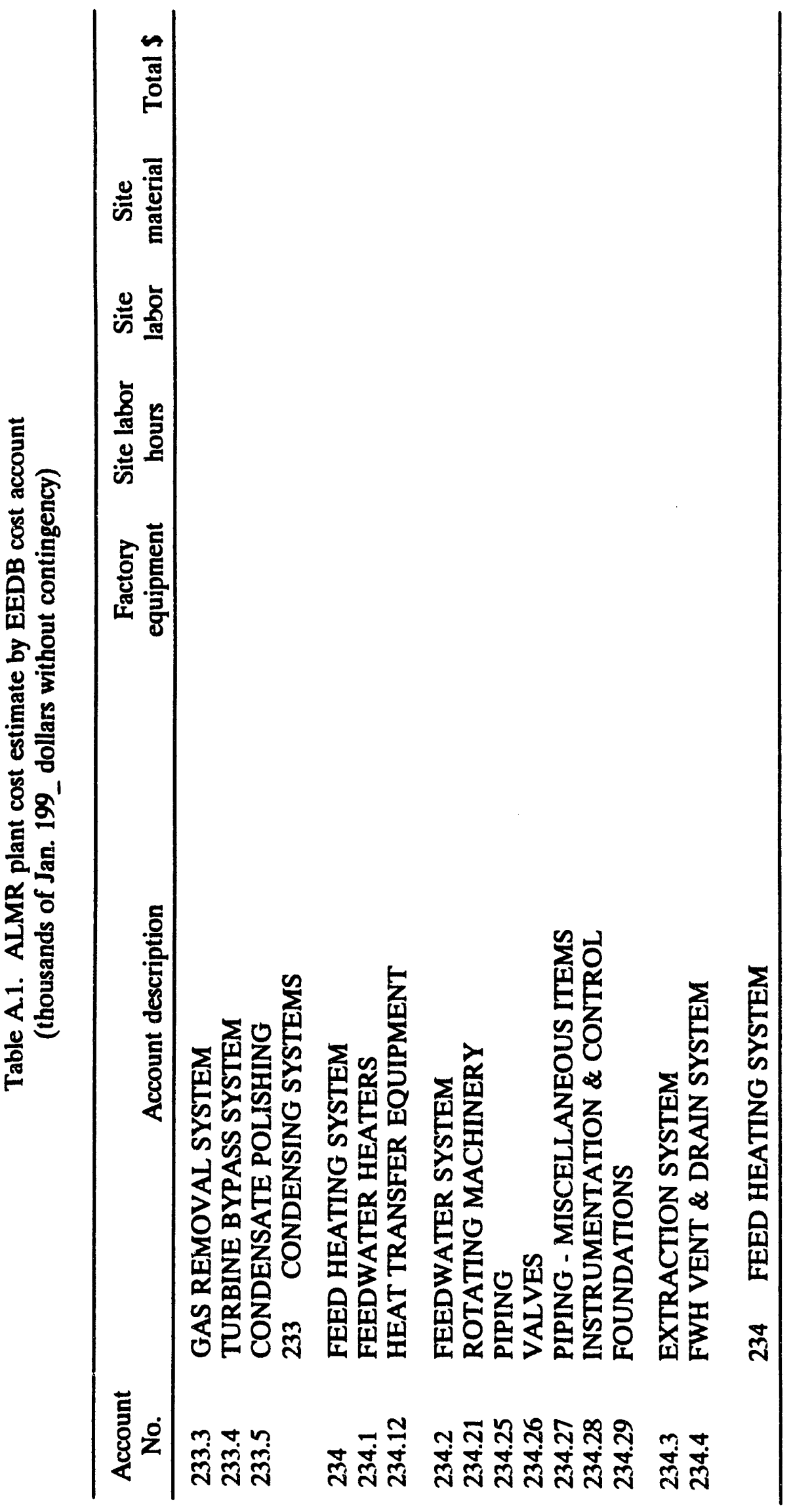




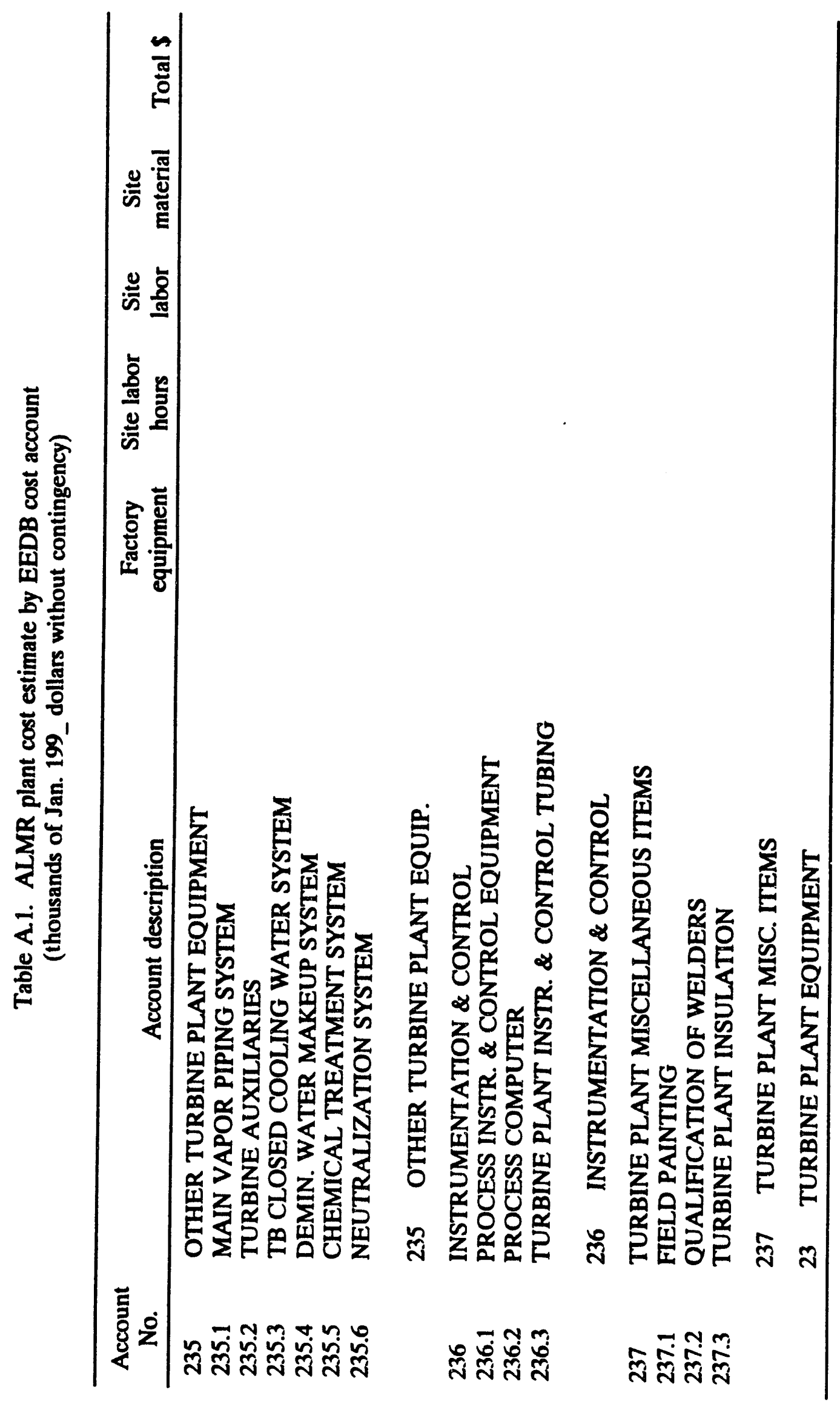




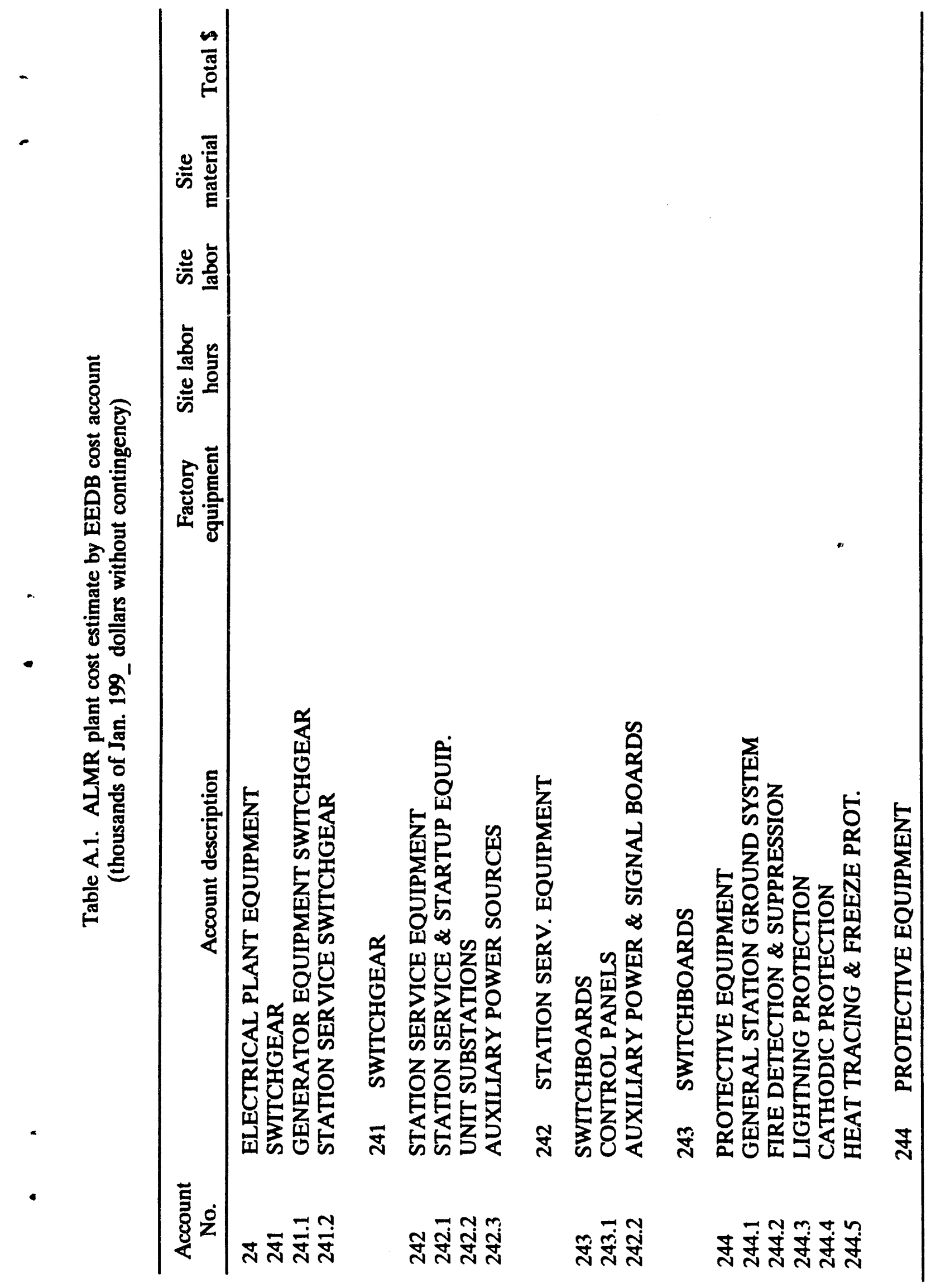




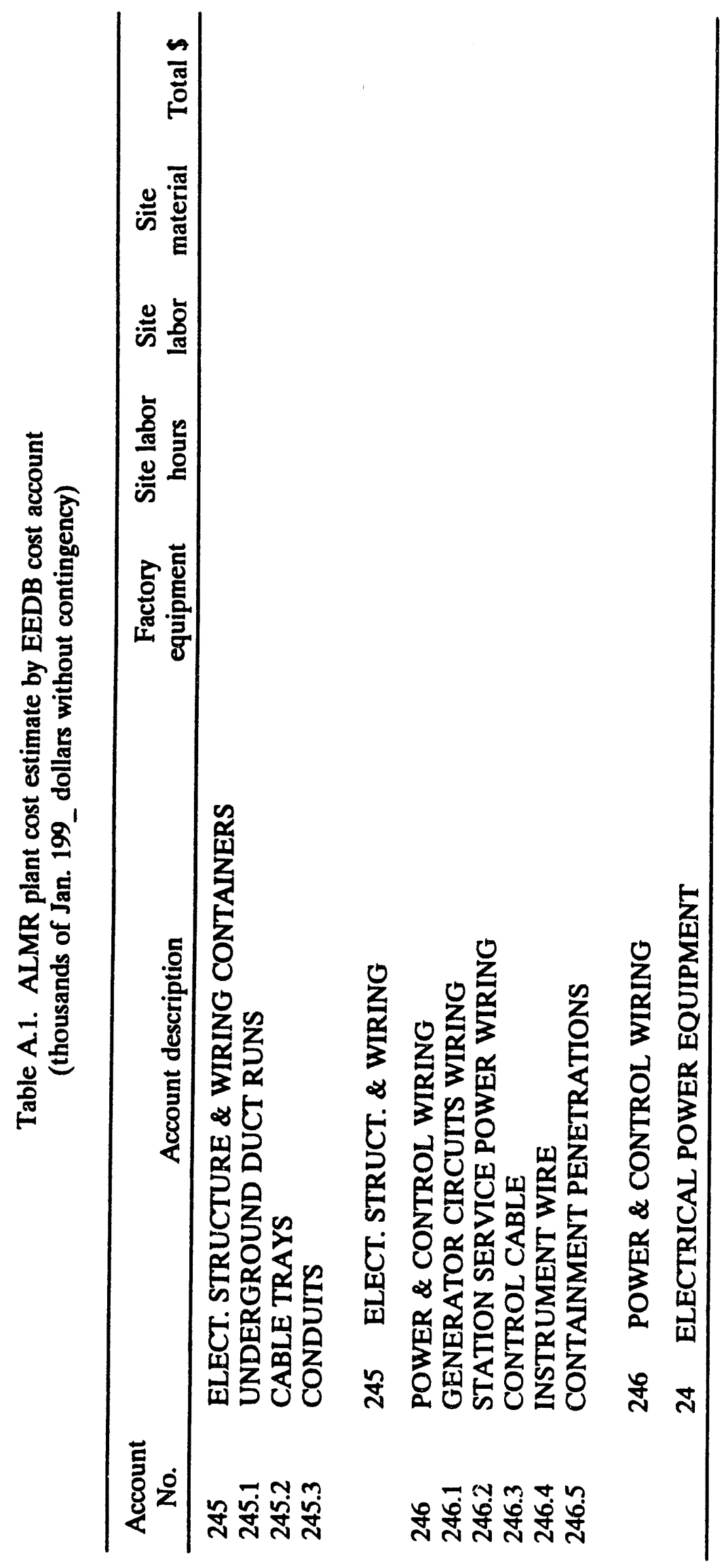




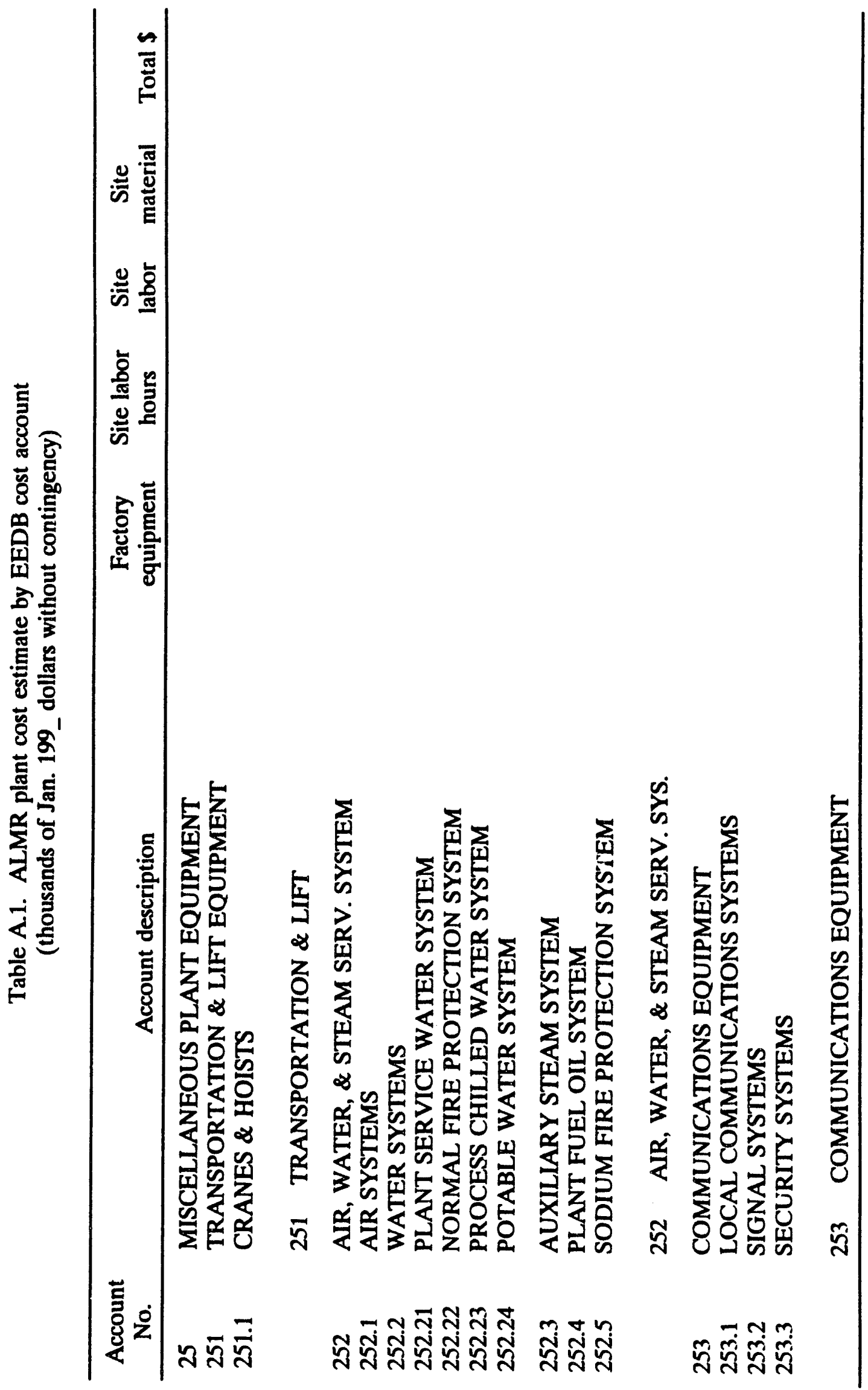




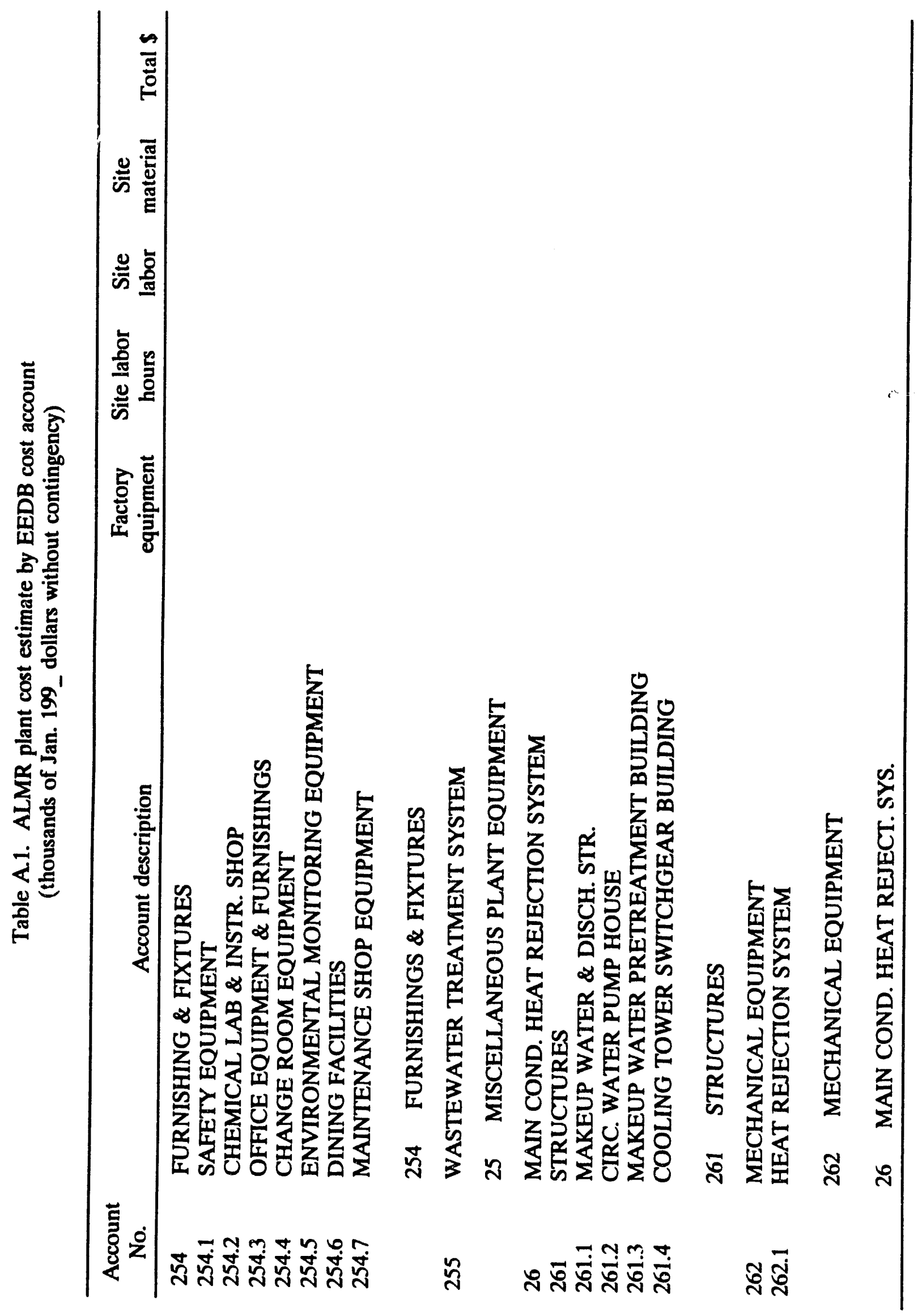




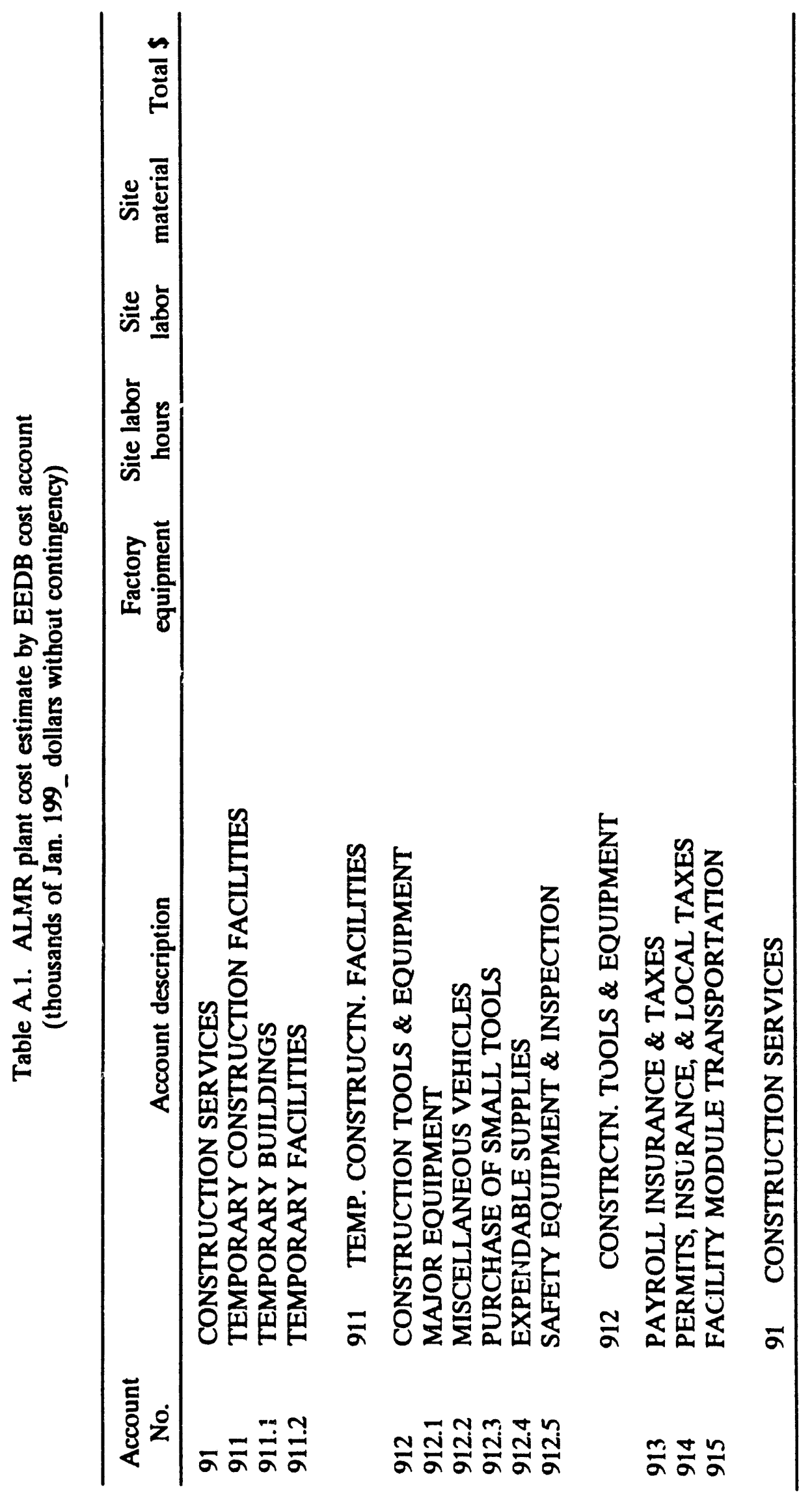




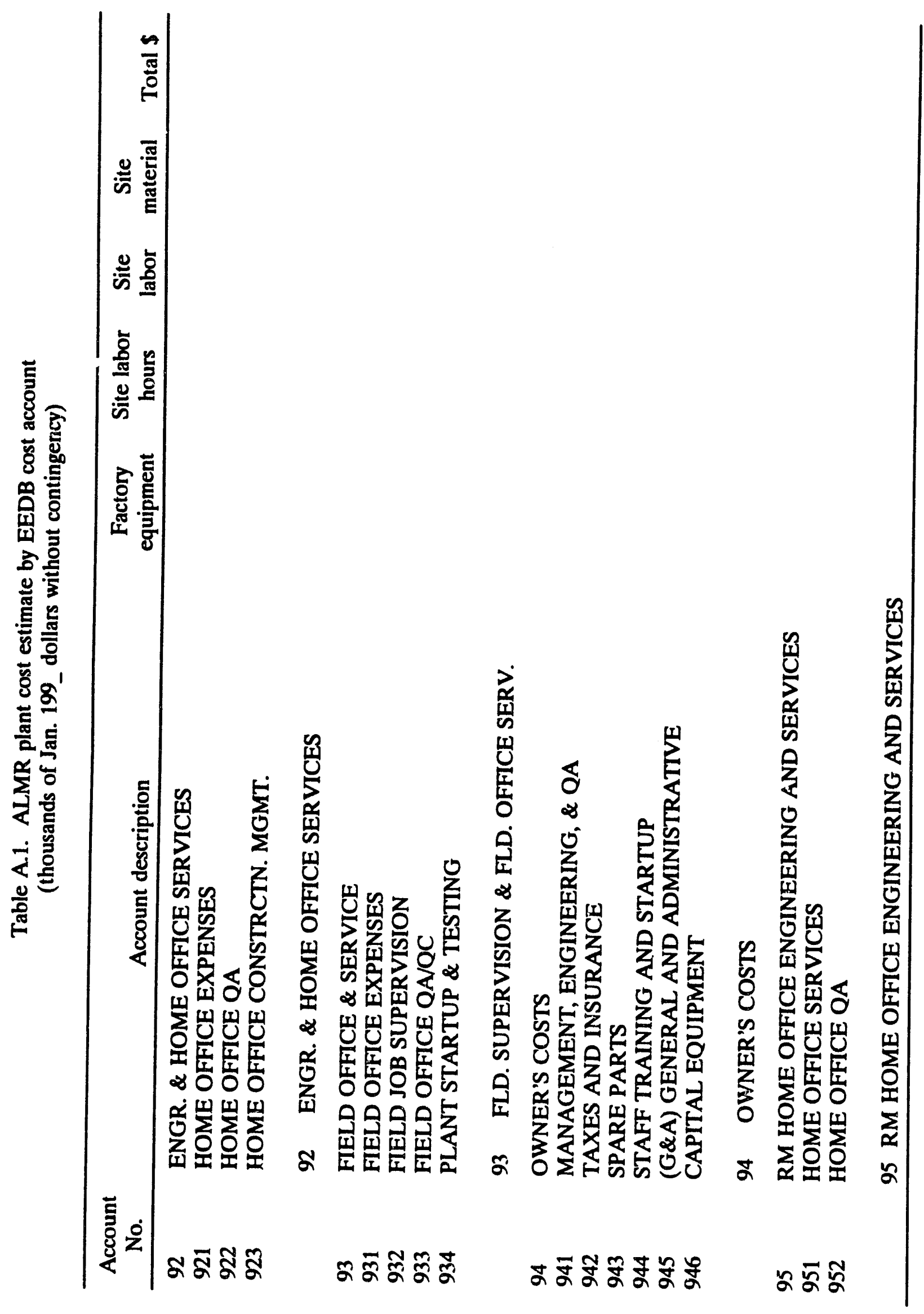


Appendix B

EEDB CODE OF ACCOUNTS FOR MODULAR HIGH-TEMPERATURE GAS-COOLED REACTOR (MHTGR) CONCEPT 


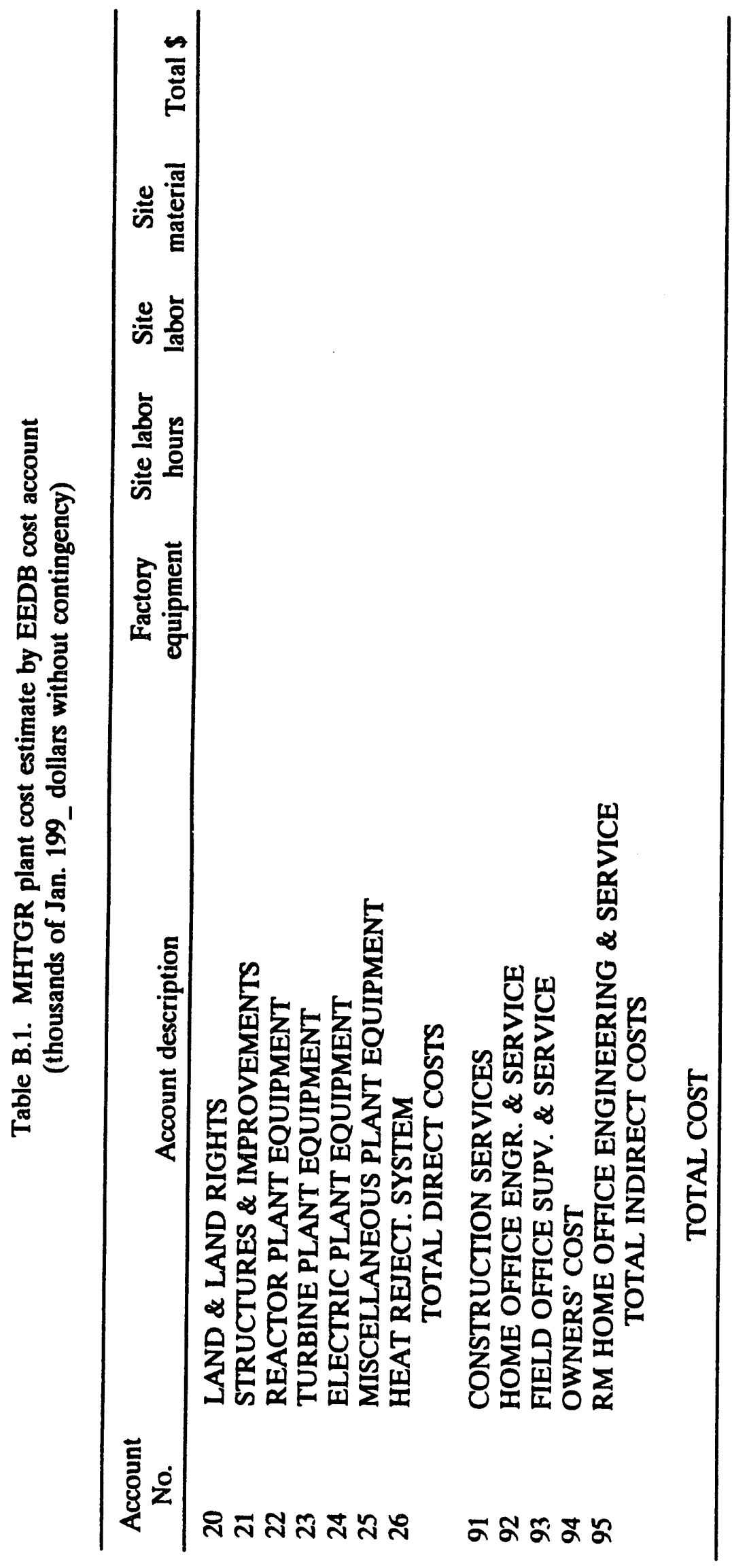




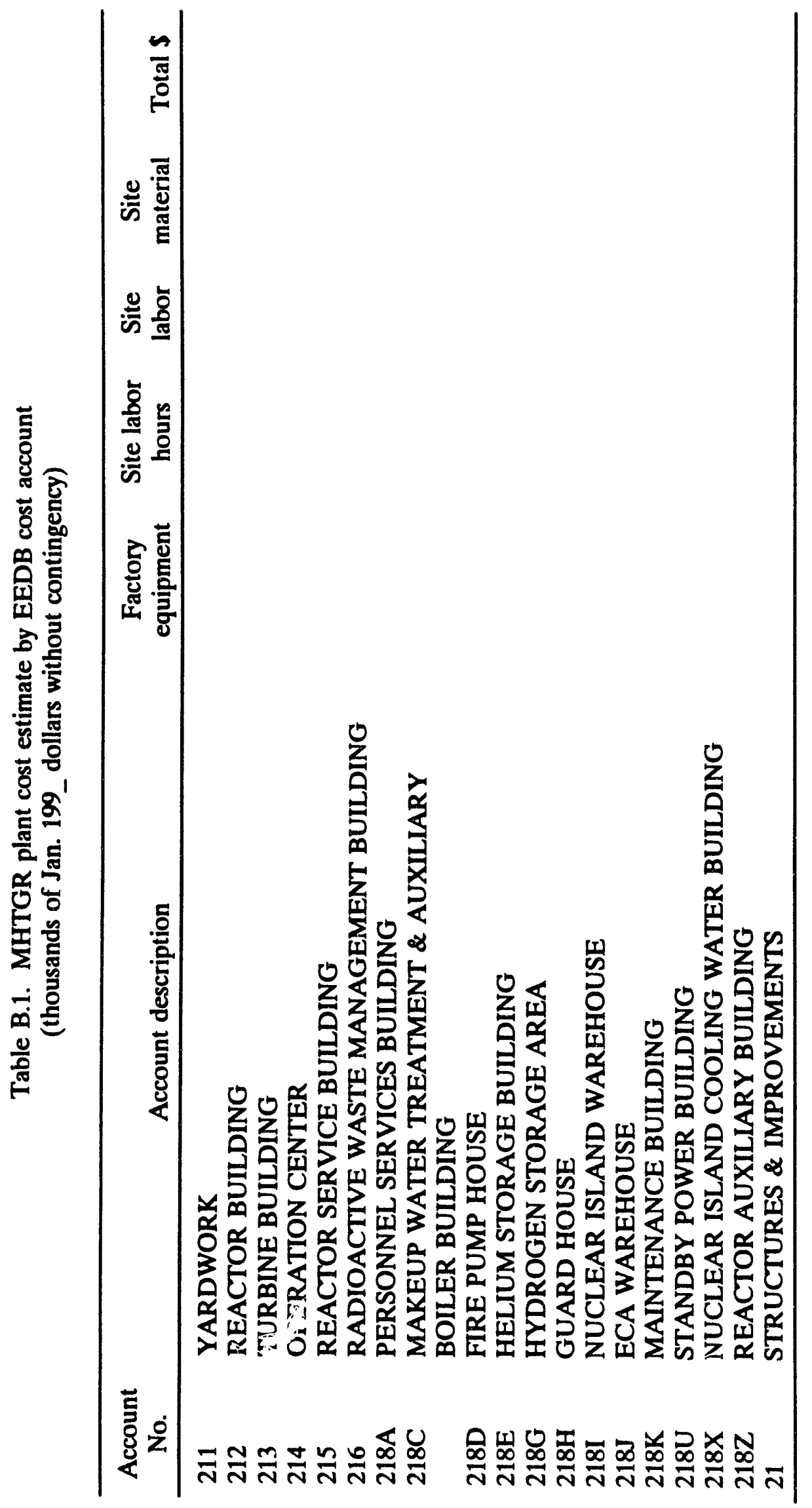




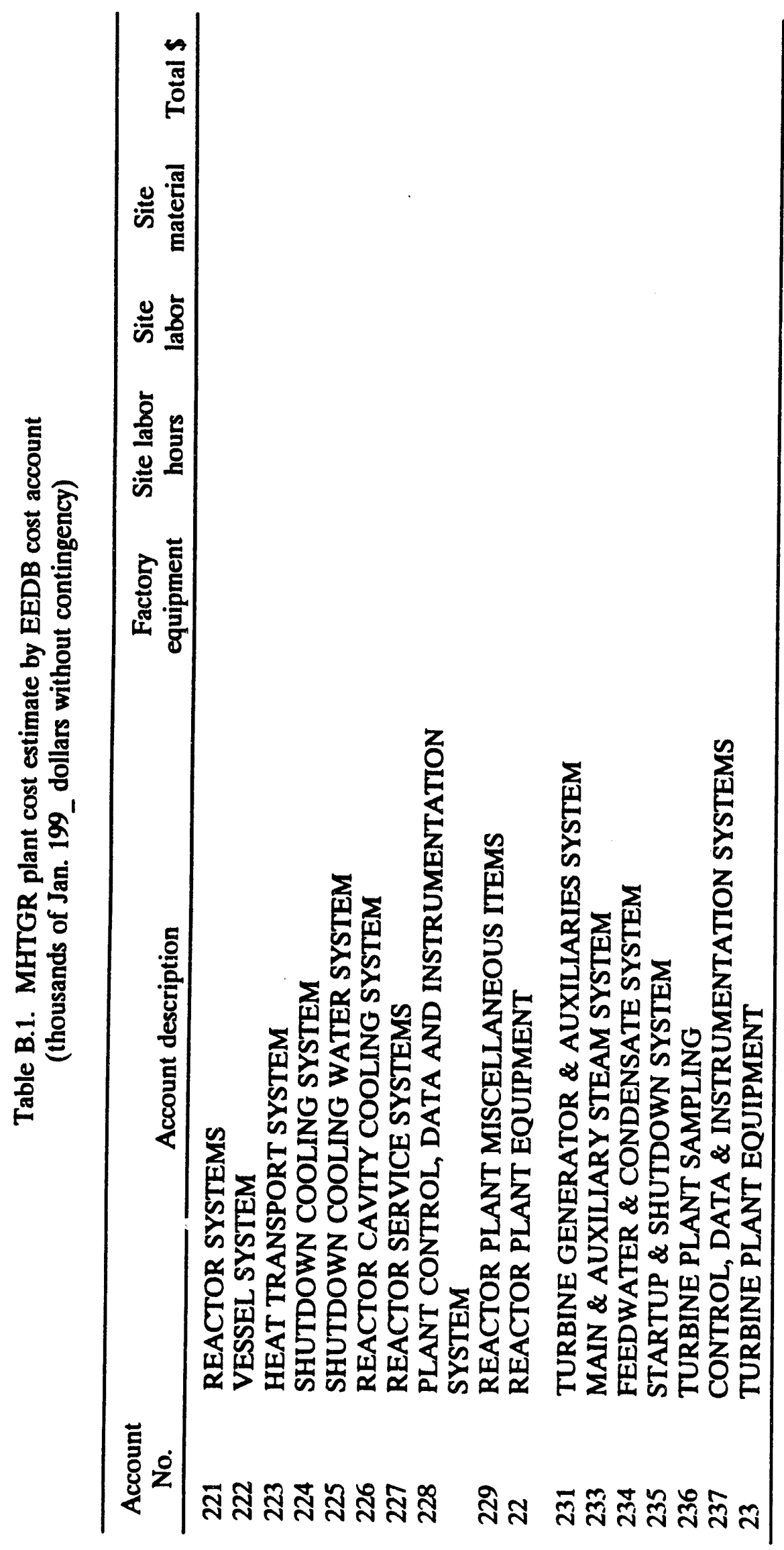




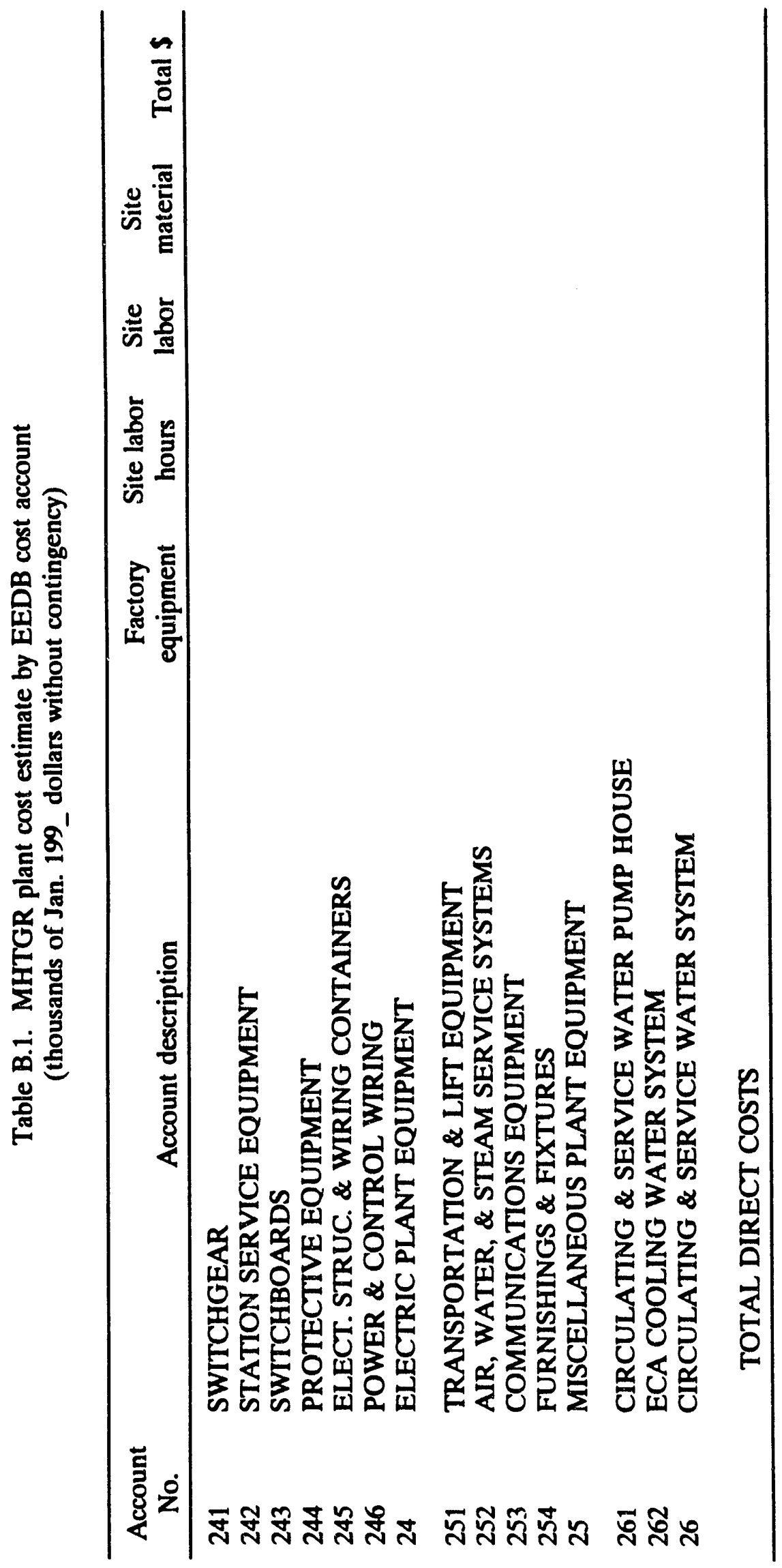




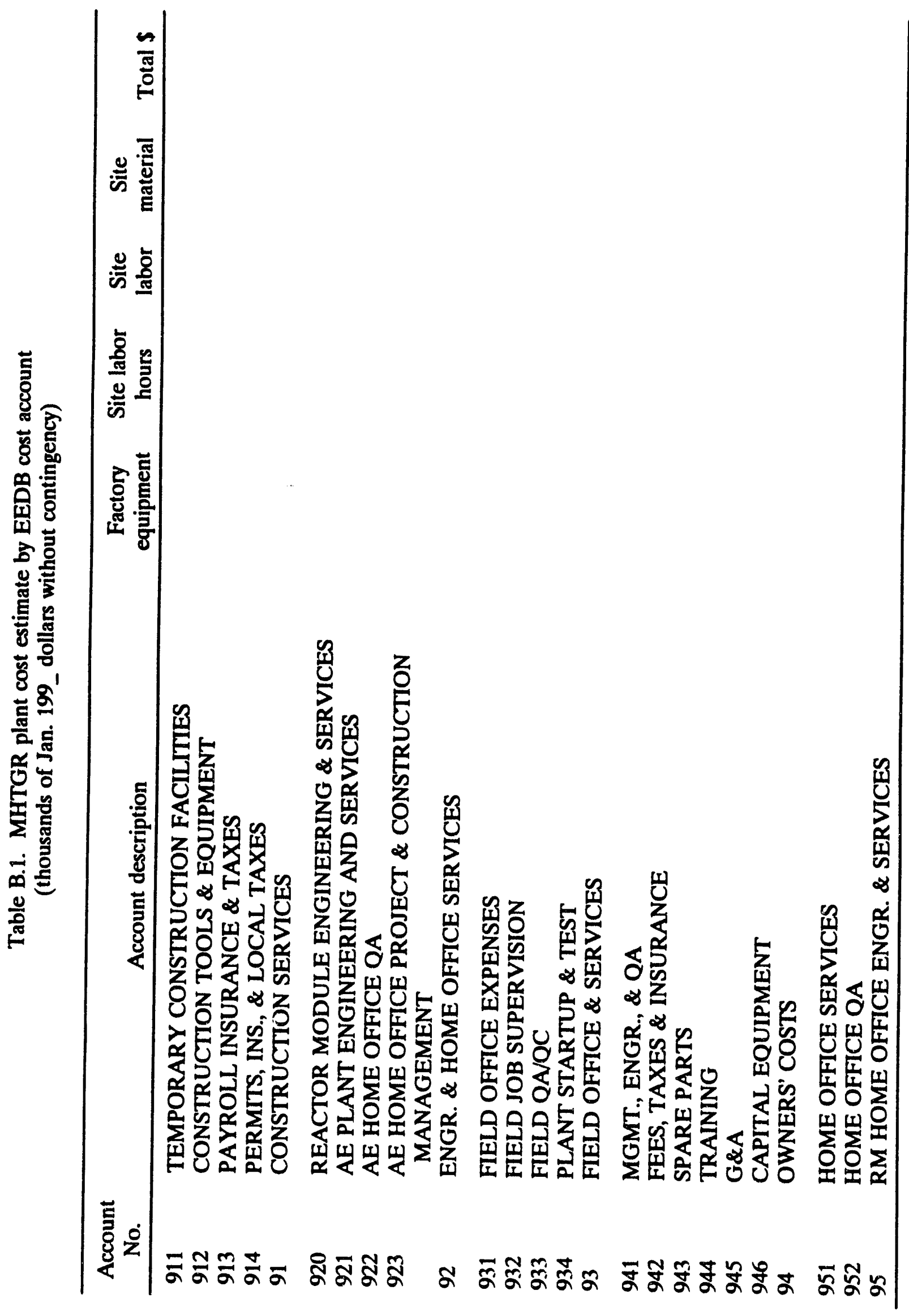


Appendix C

EEDB CODE OF ACCOUNTS FOR THE REFERENCE PRESSURIZED WATER REACTOR (PWR) 


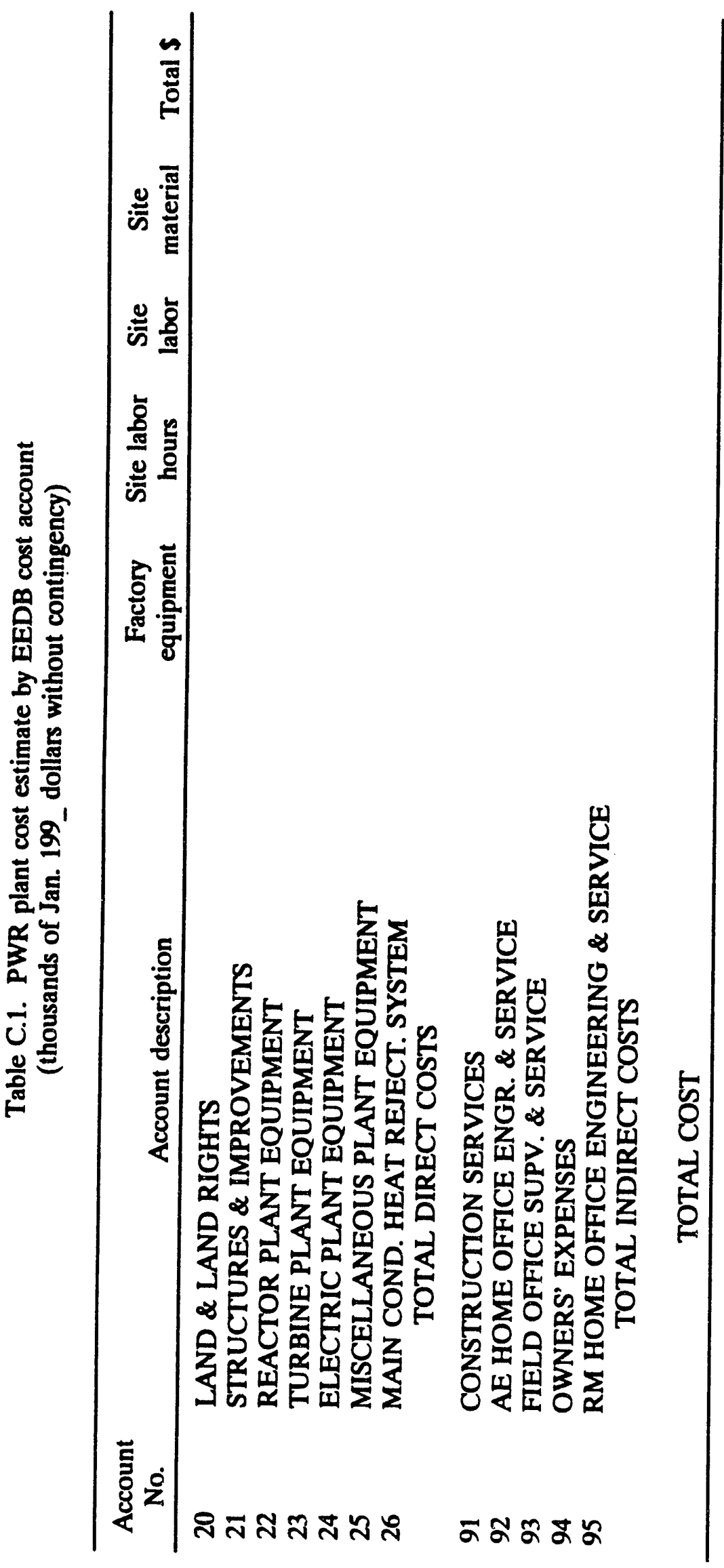




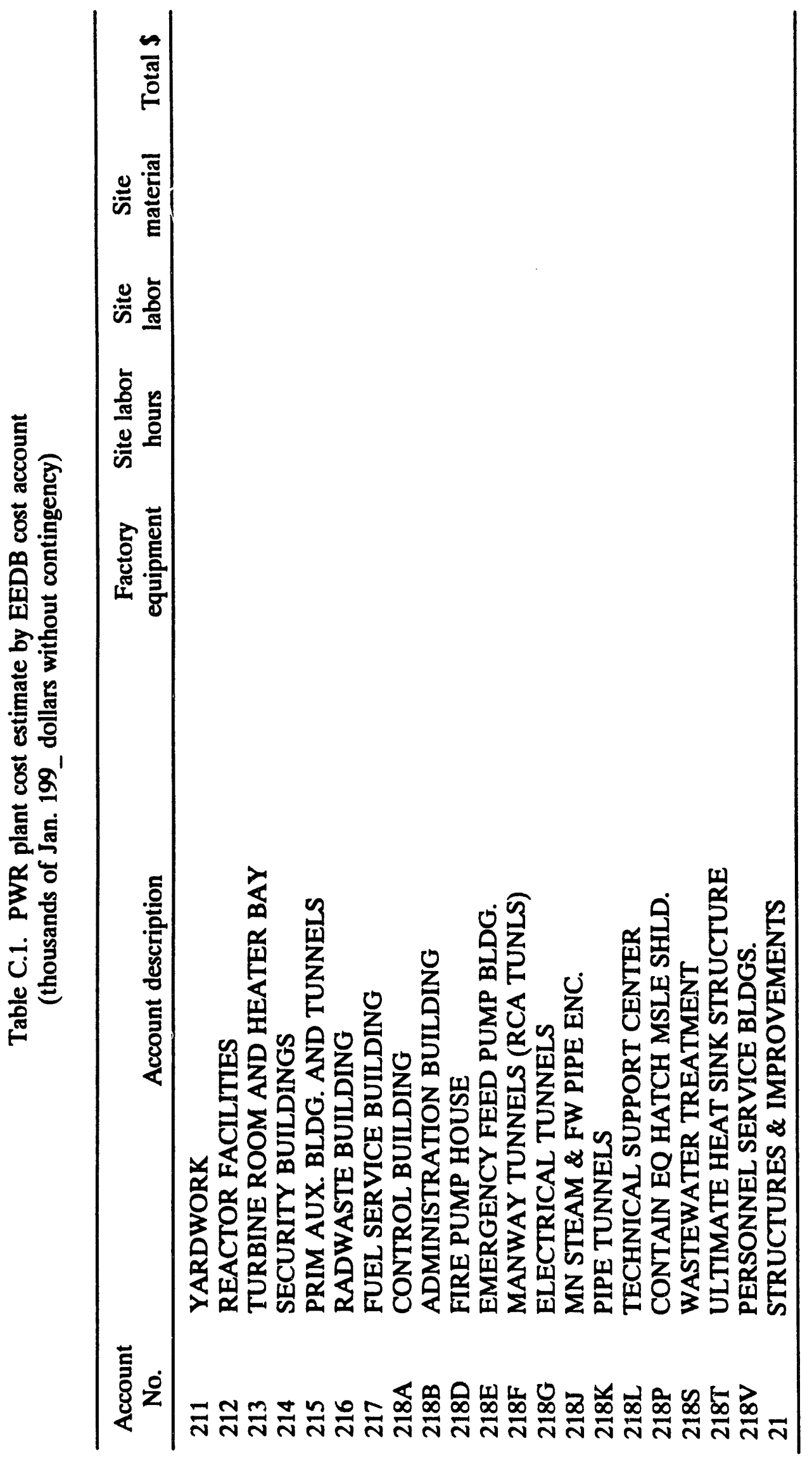




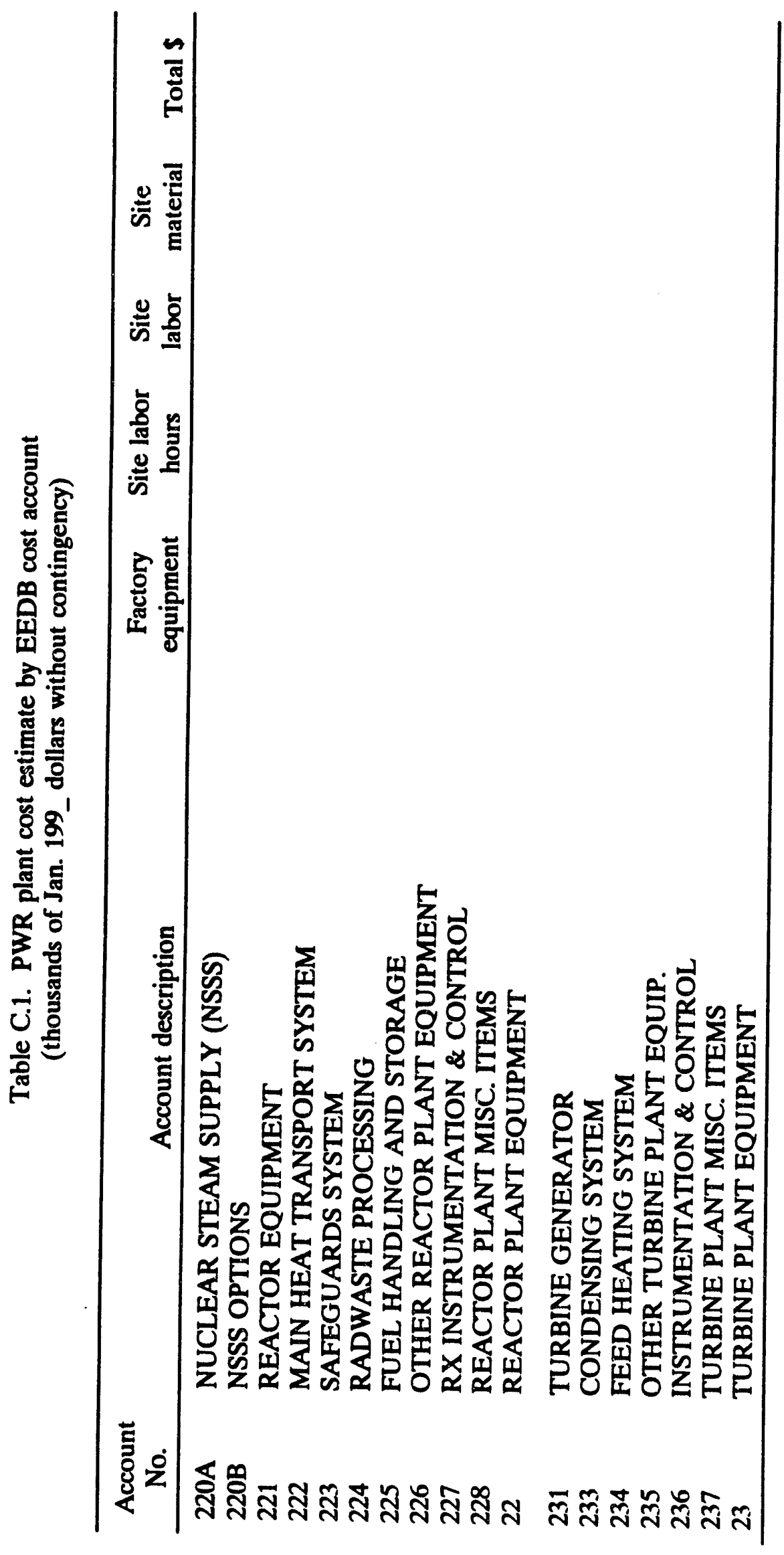




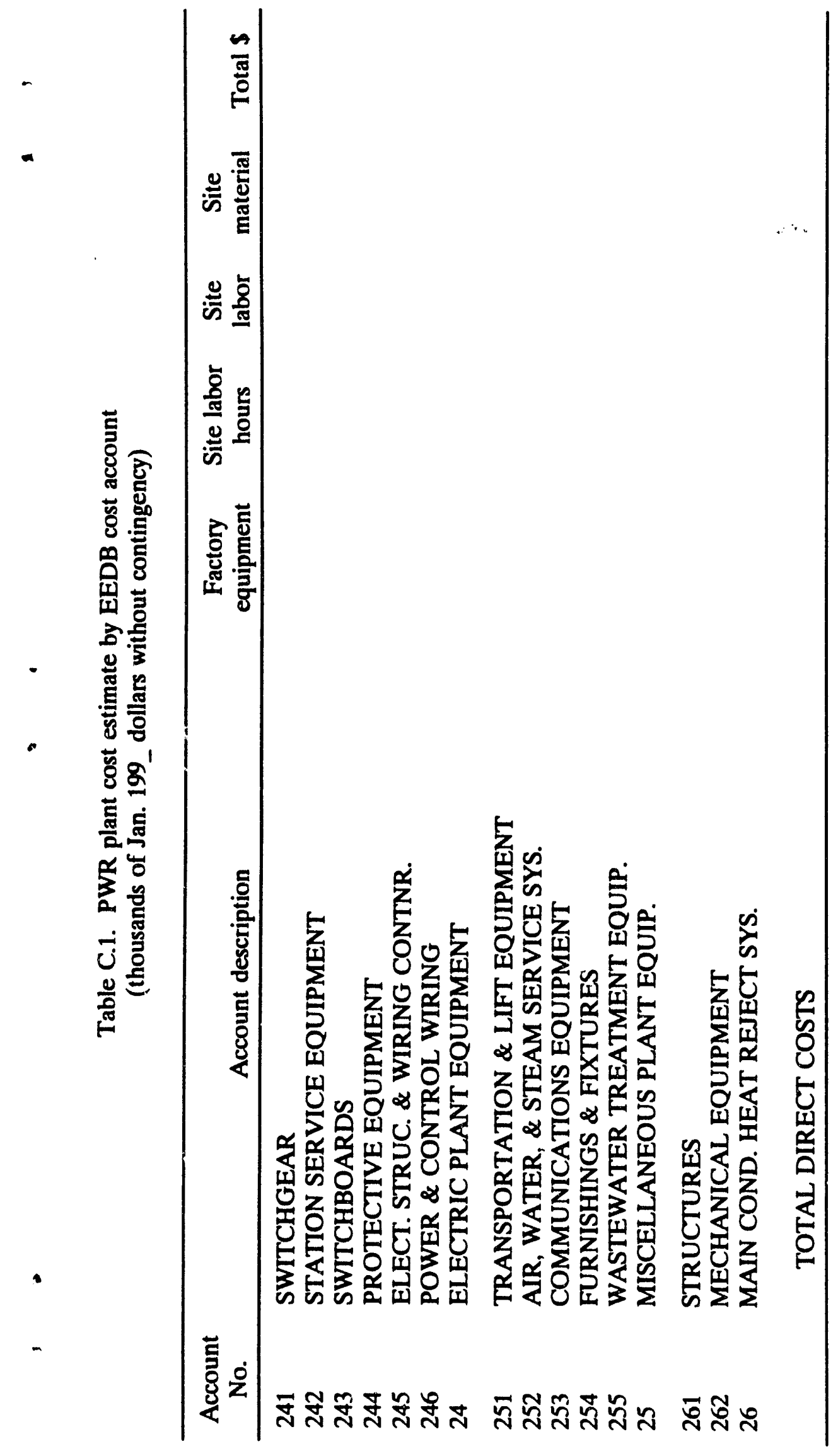




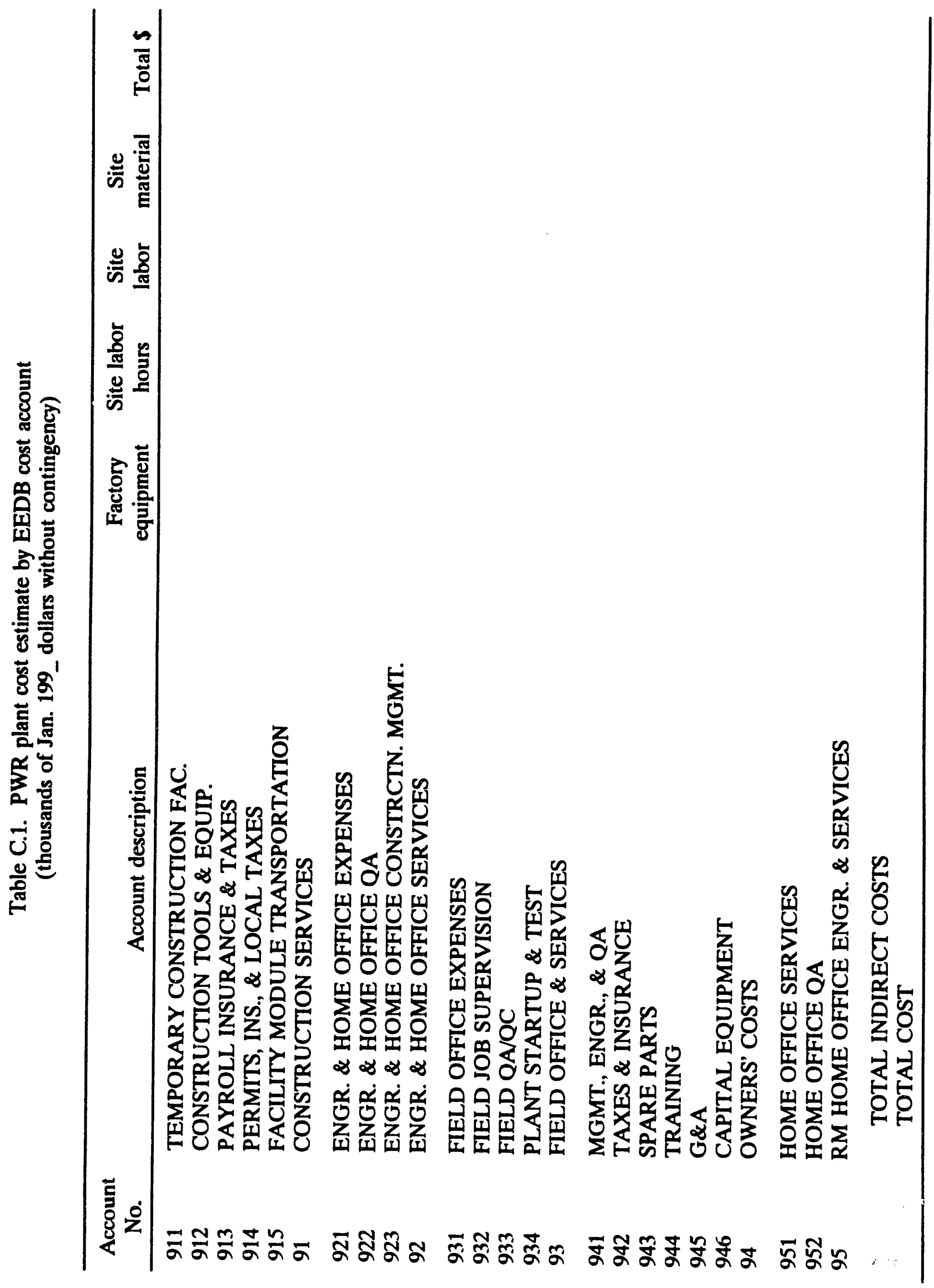




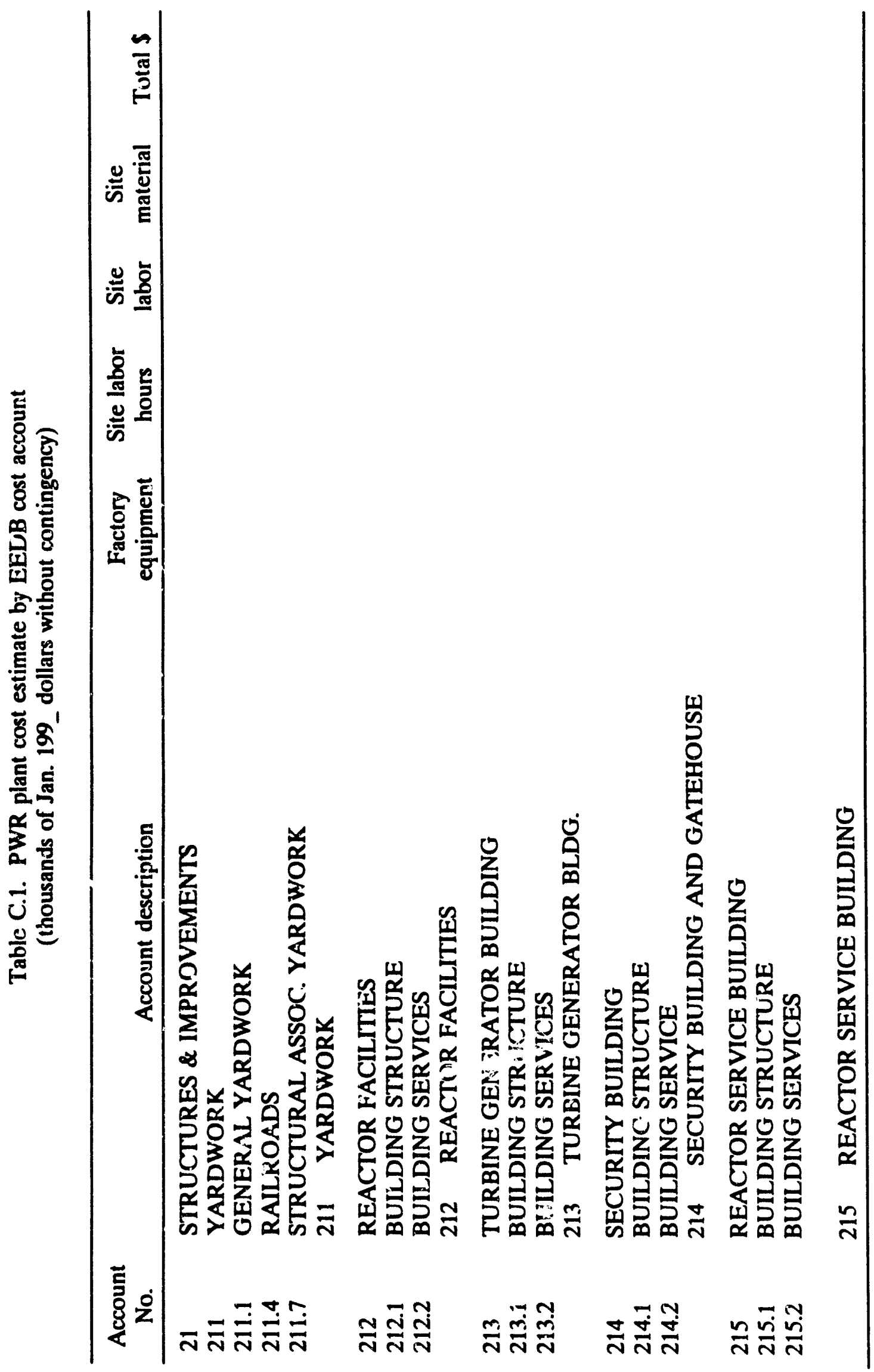




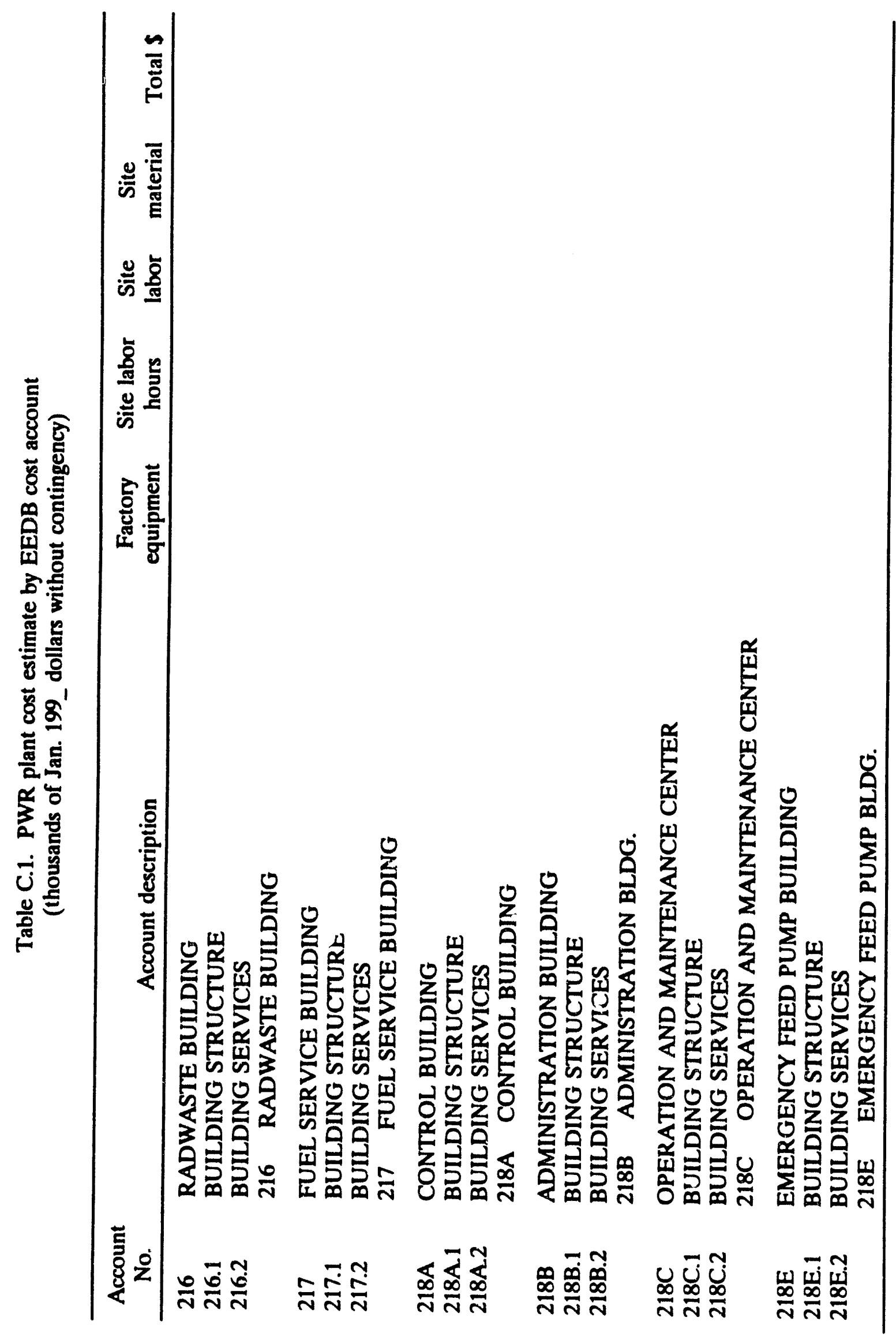




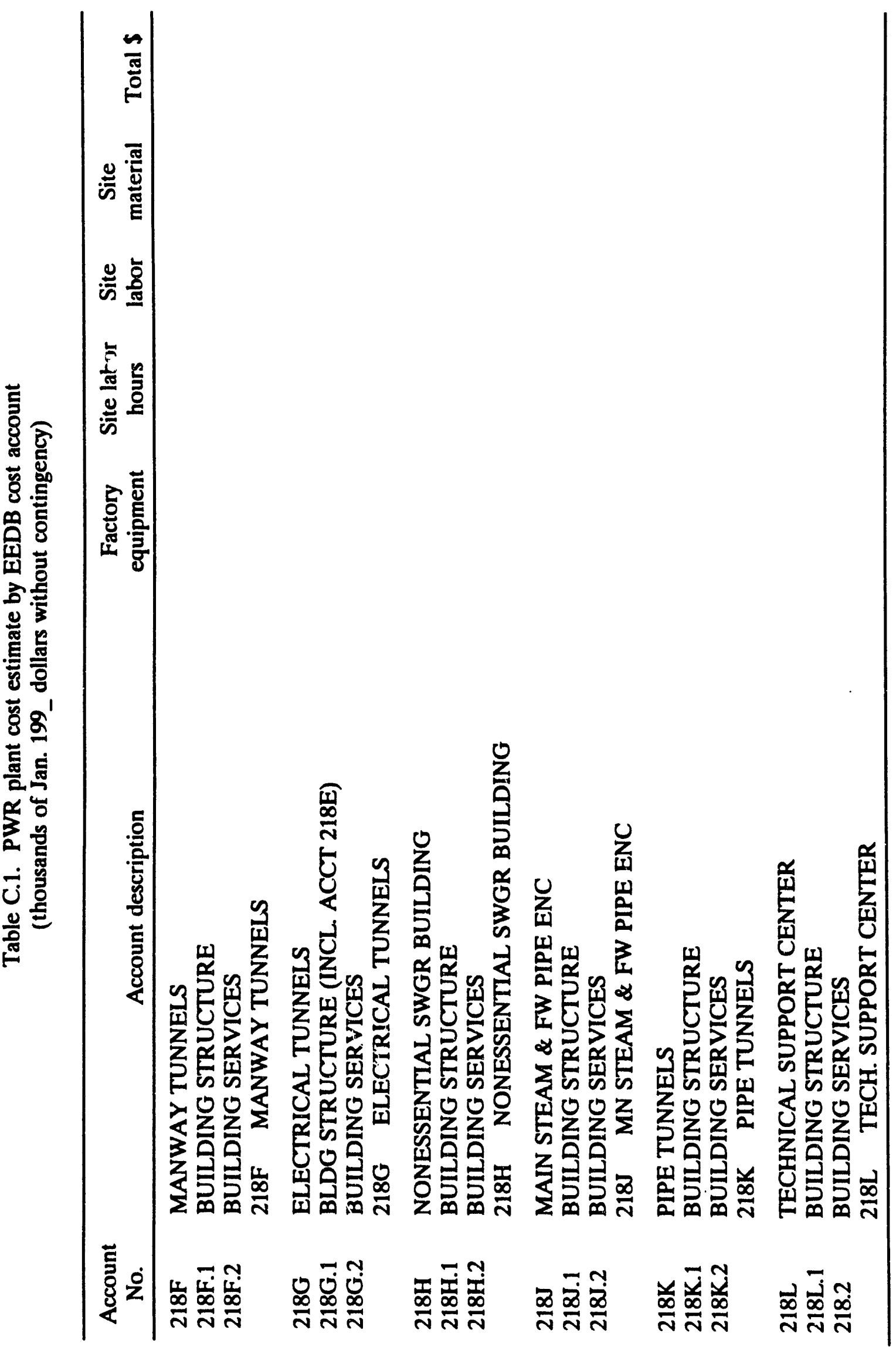




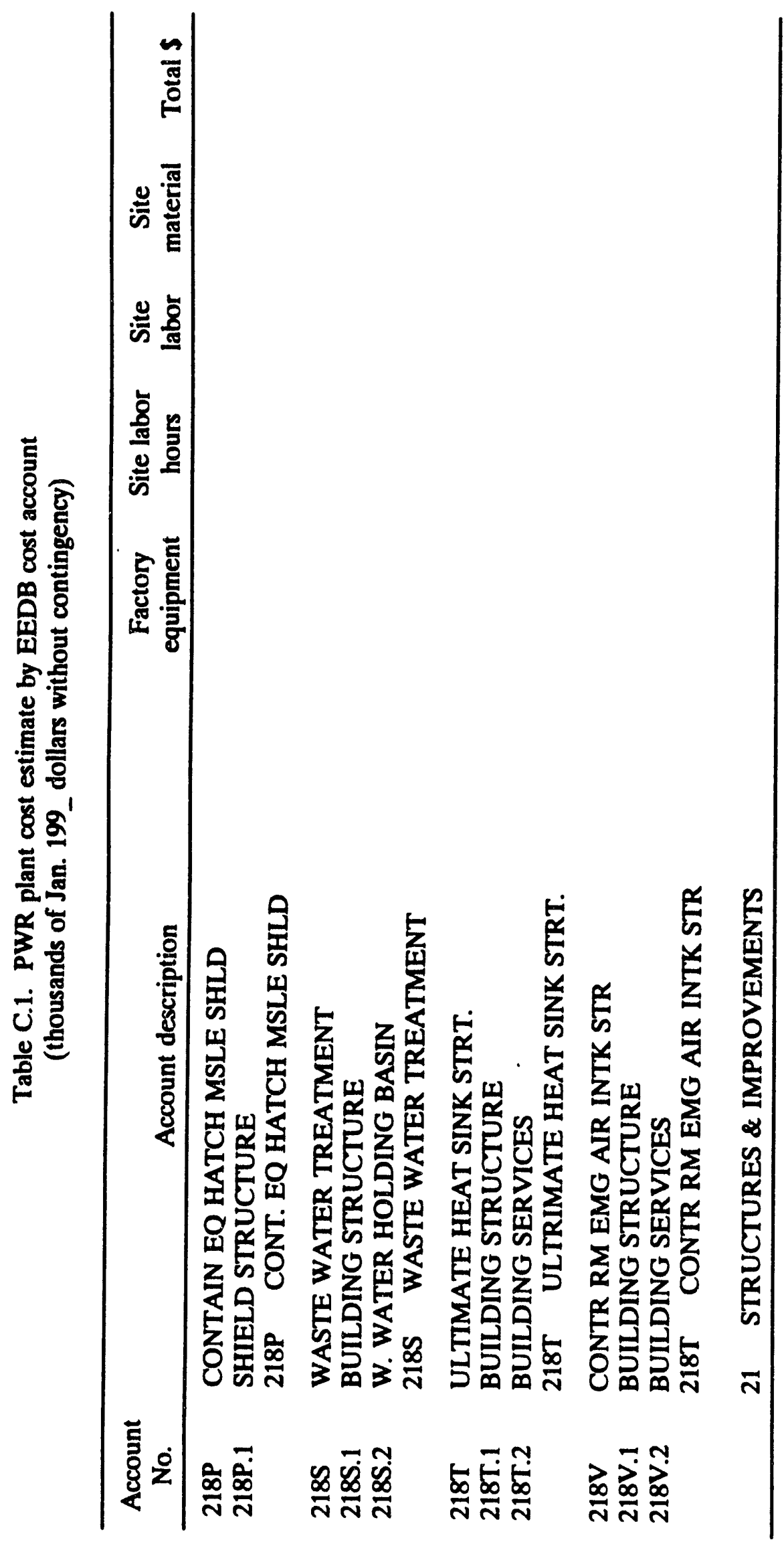




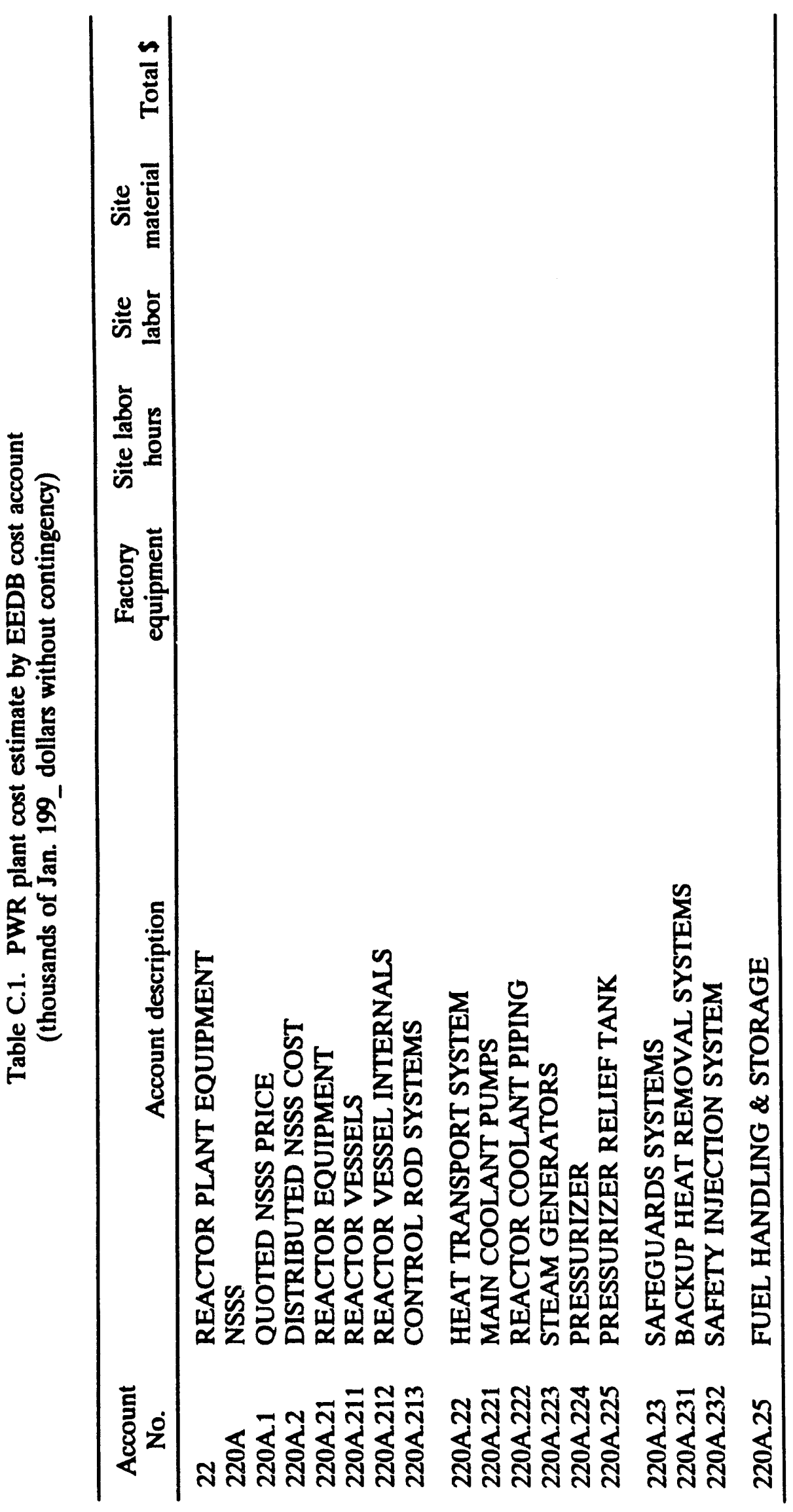




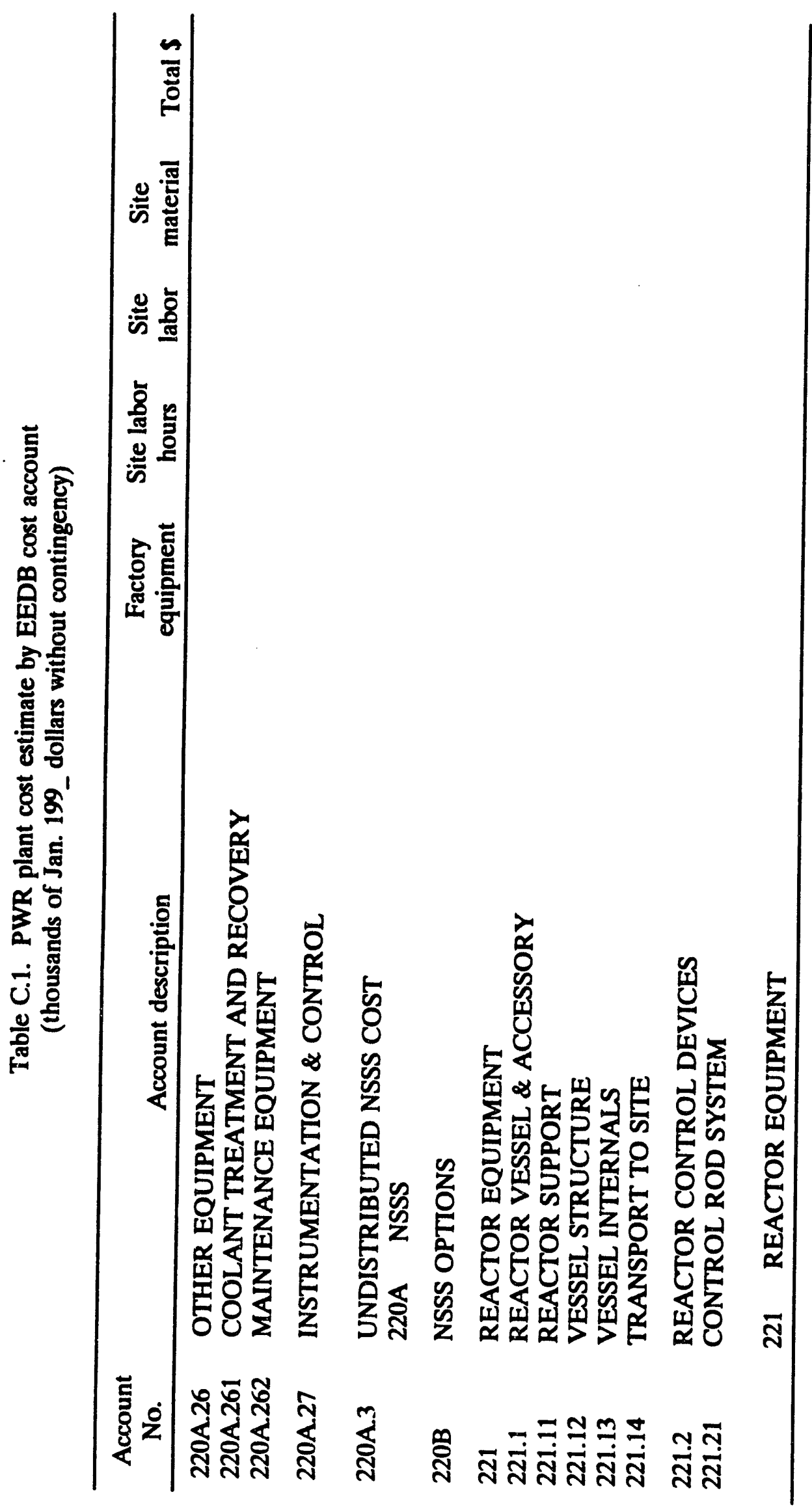




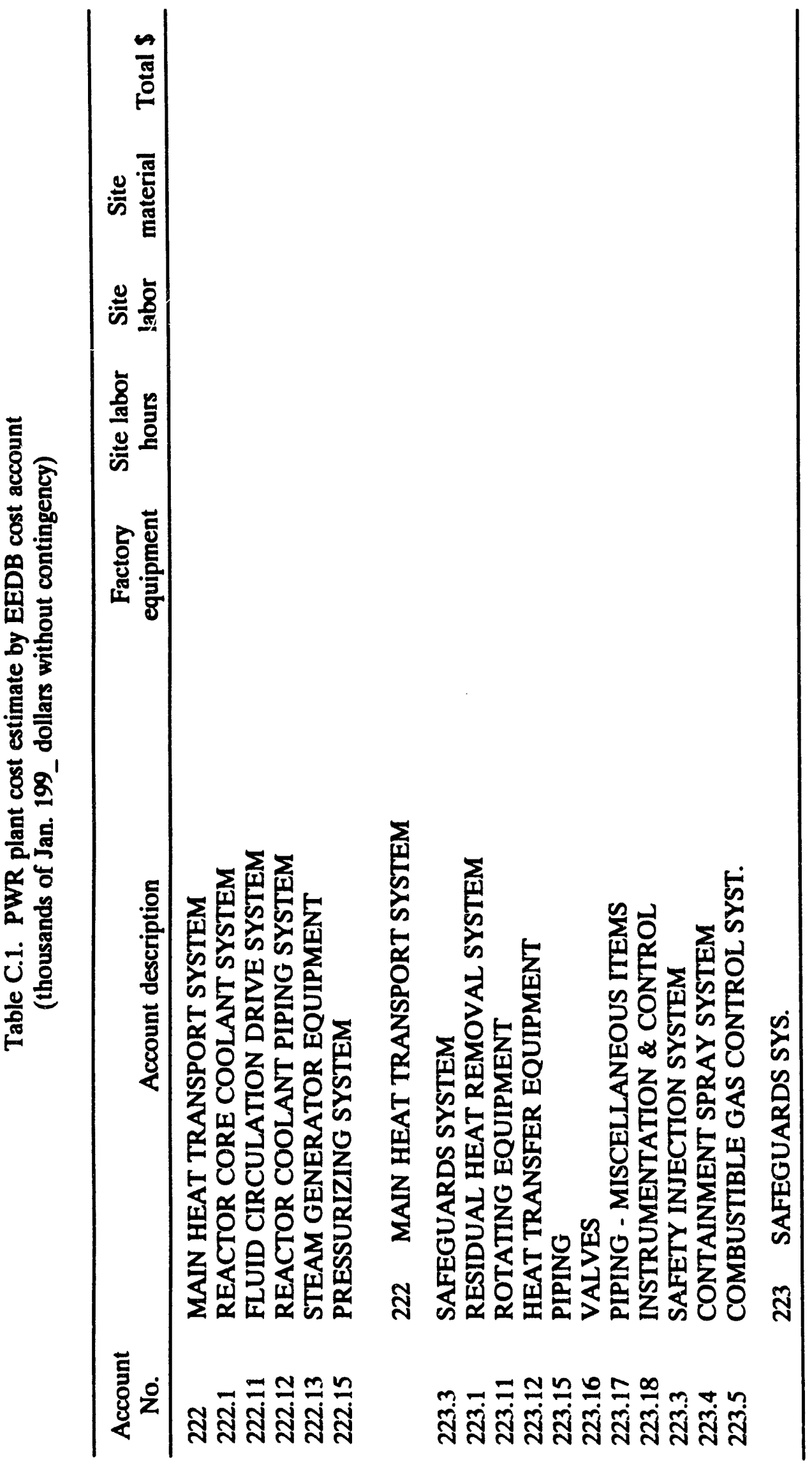




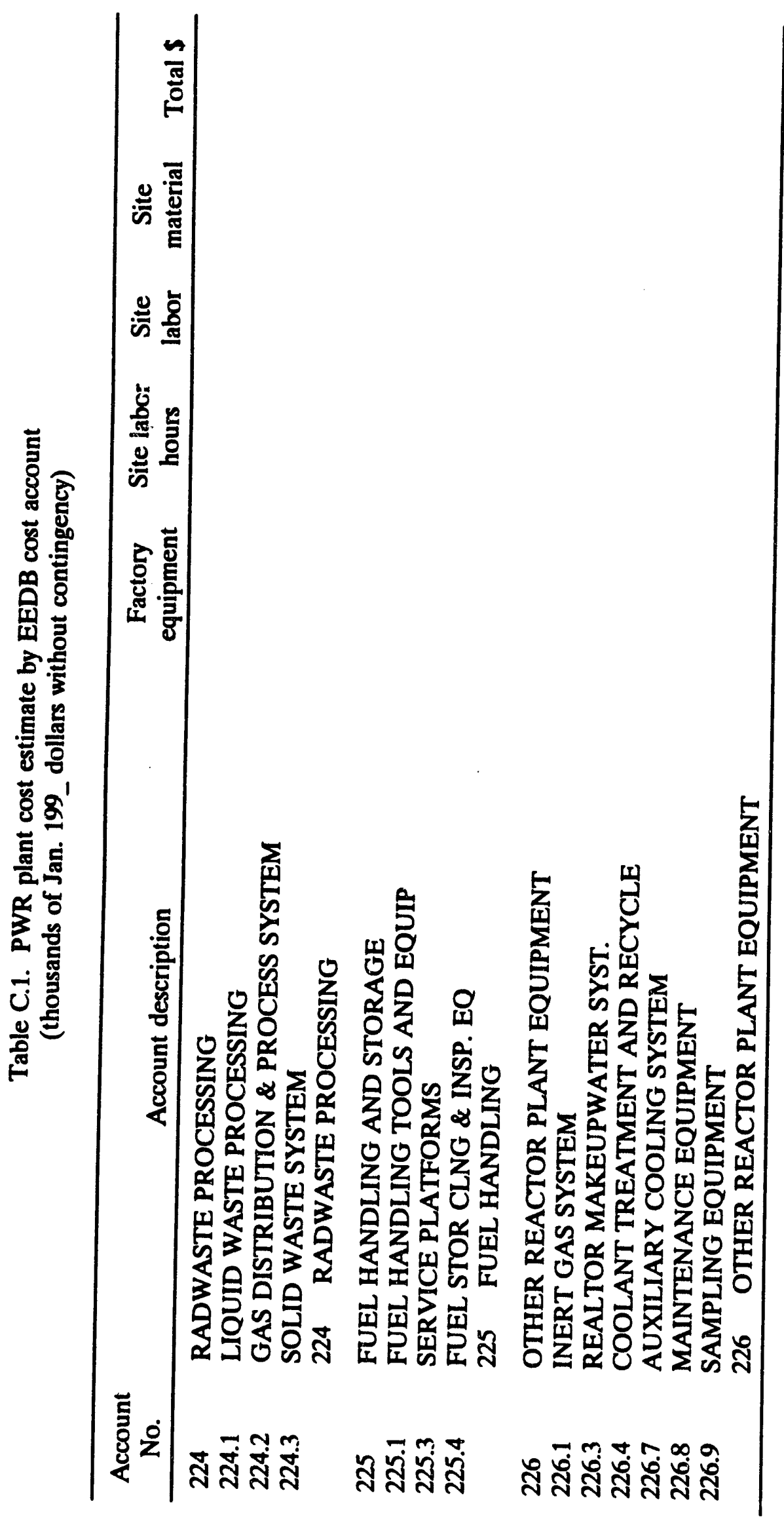




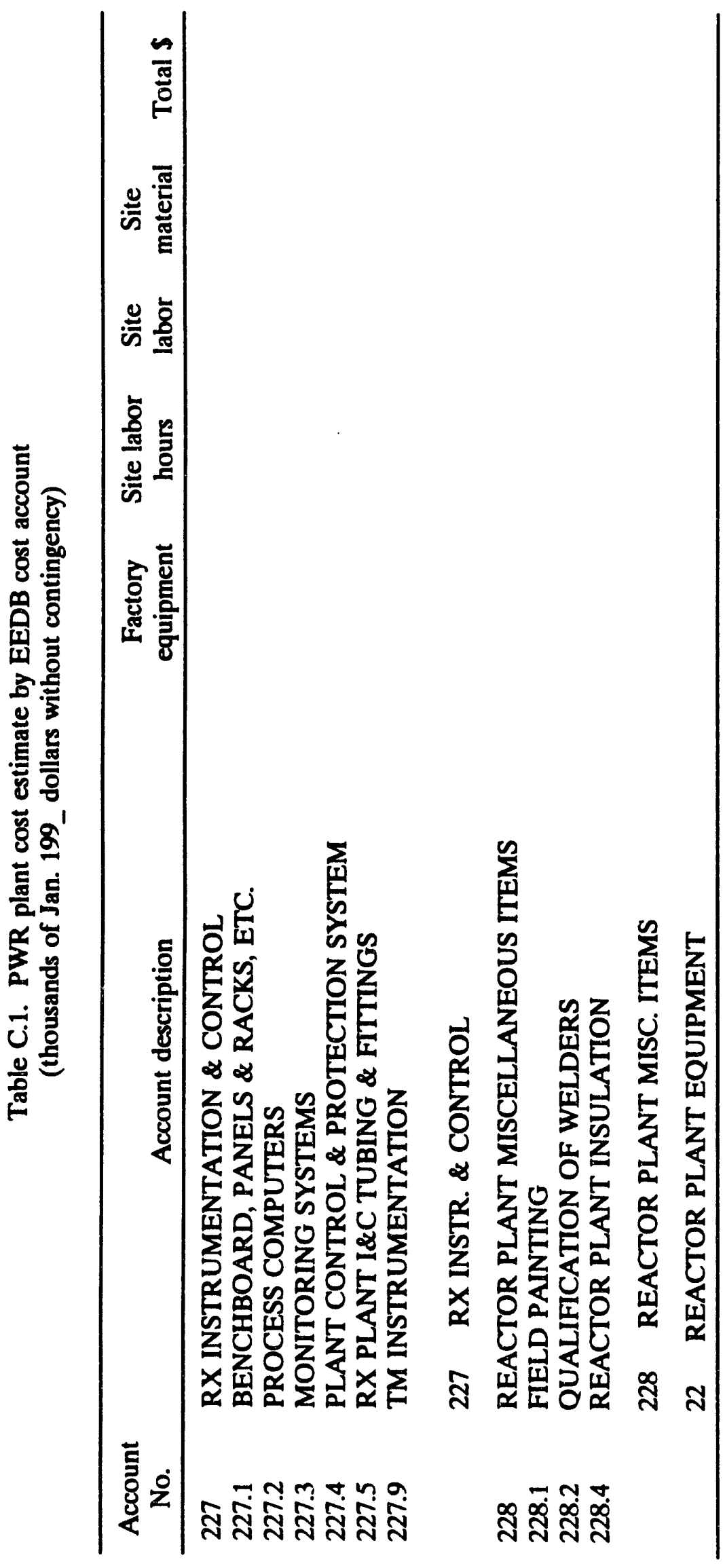




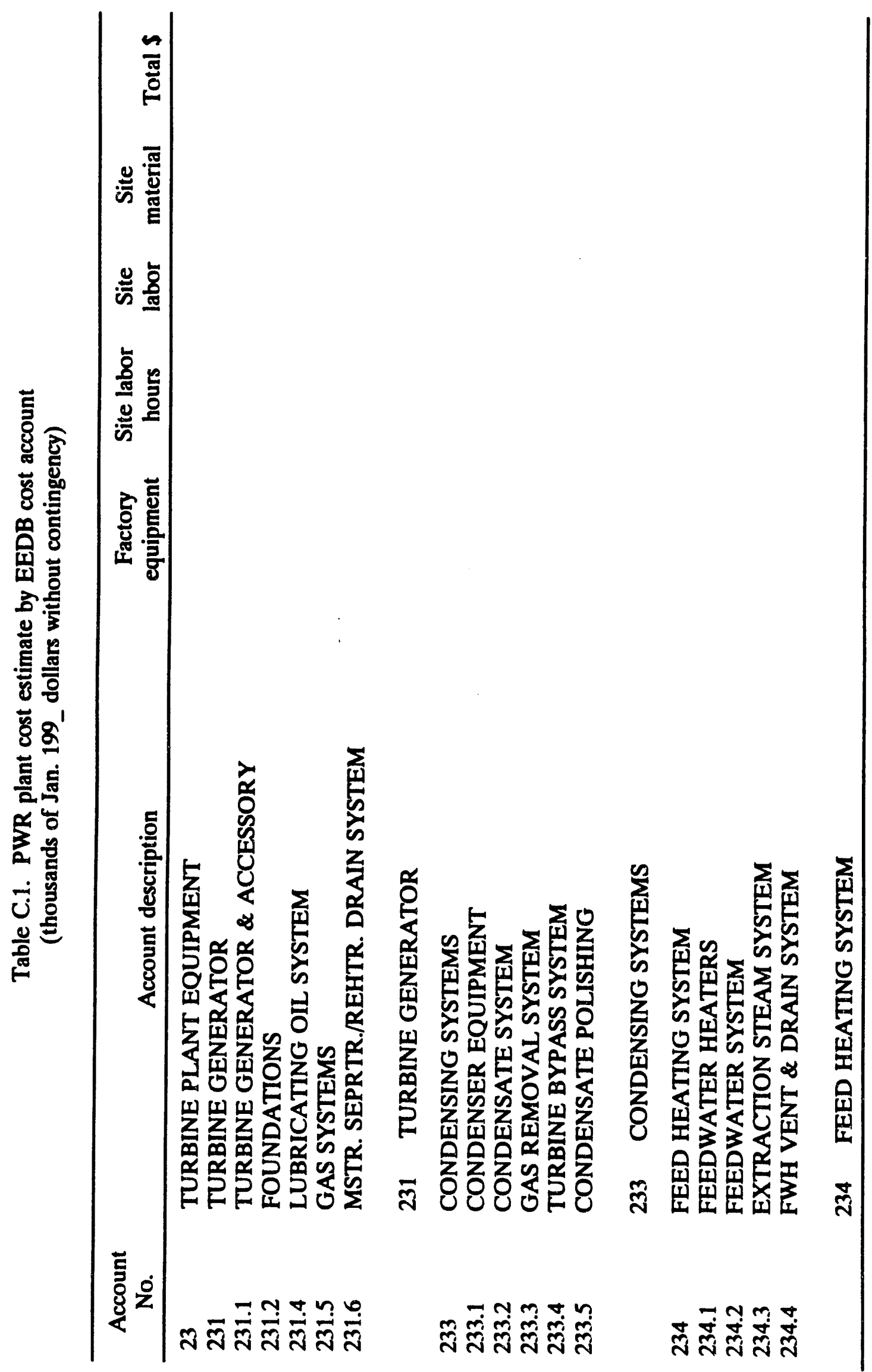




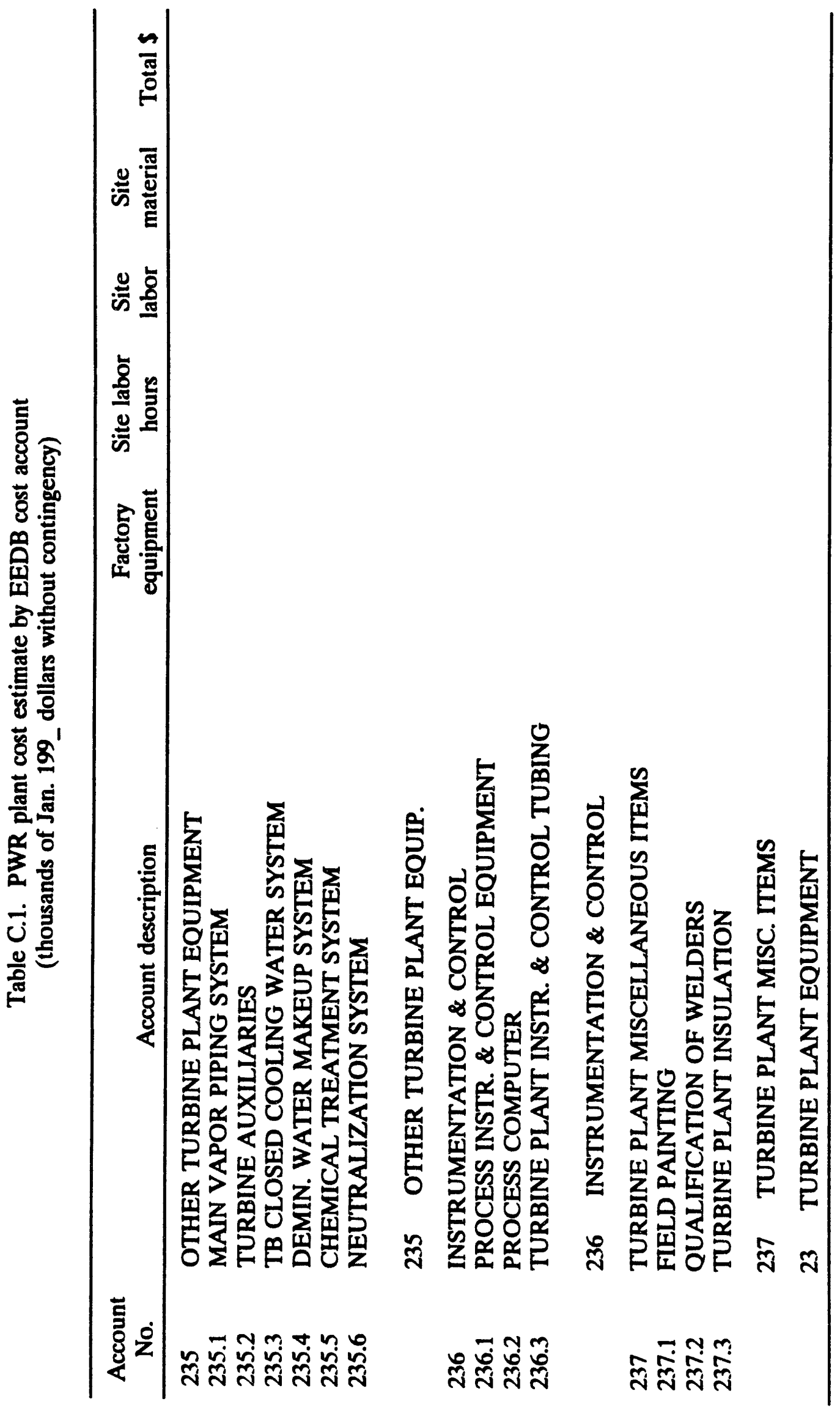




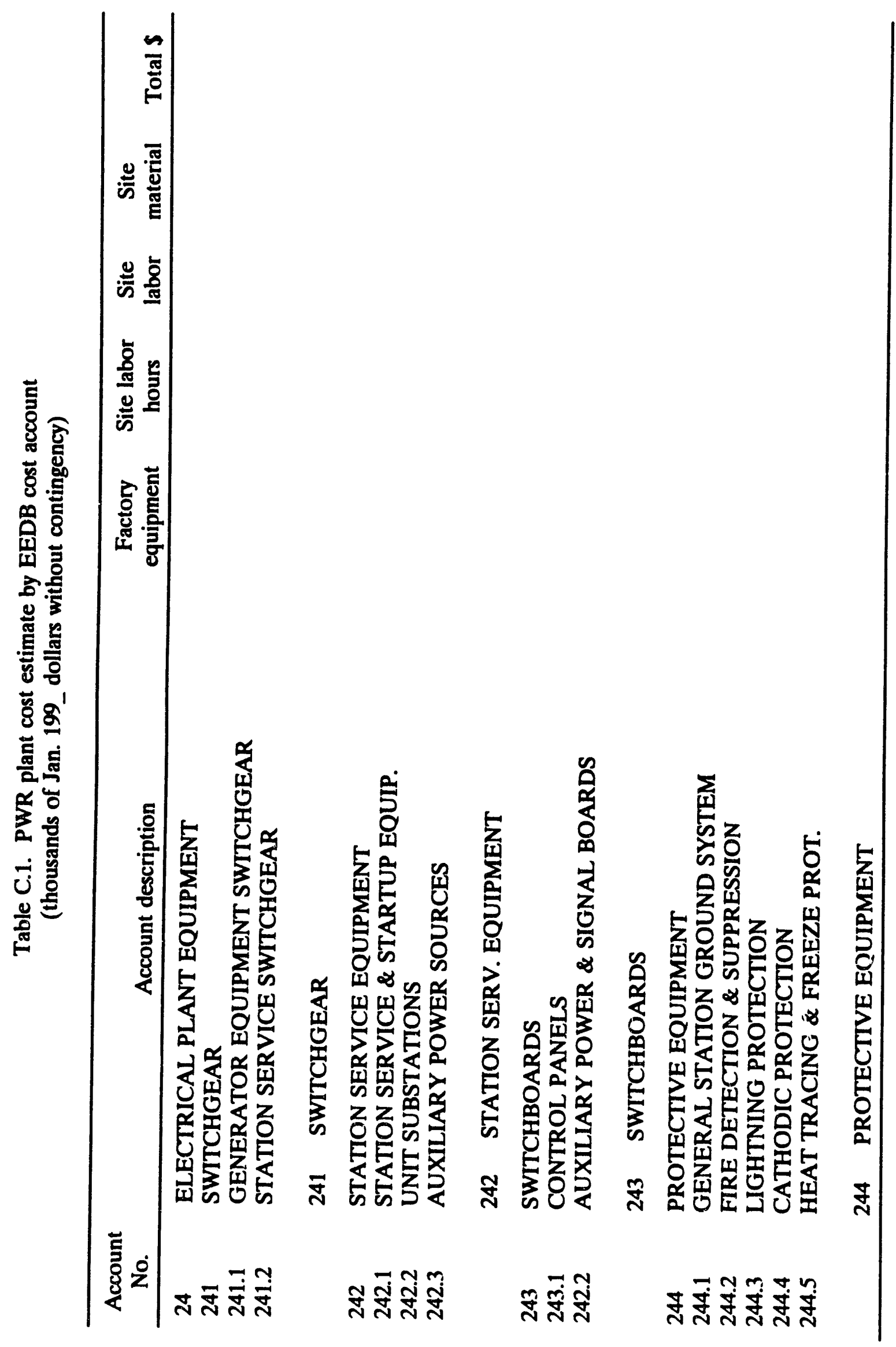




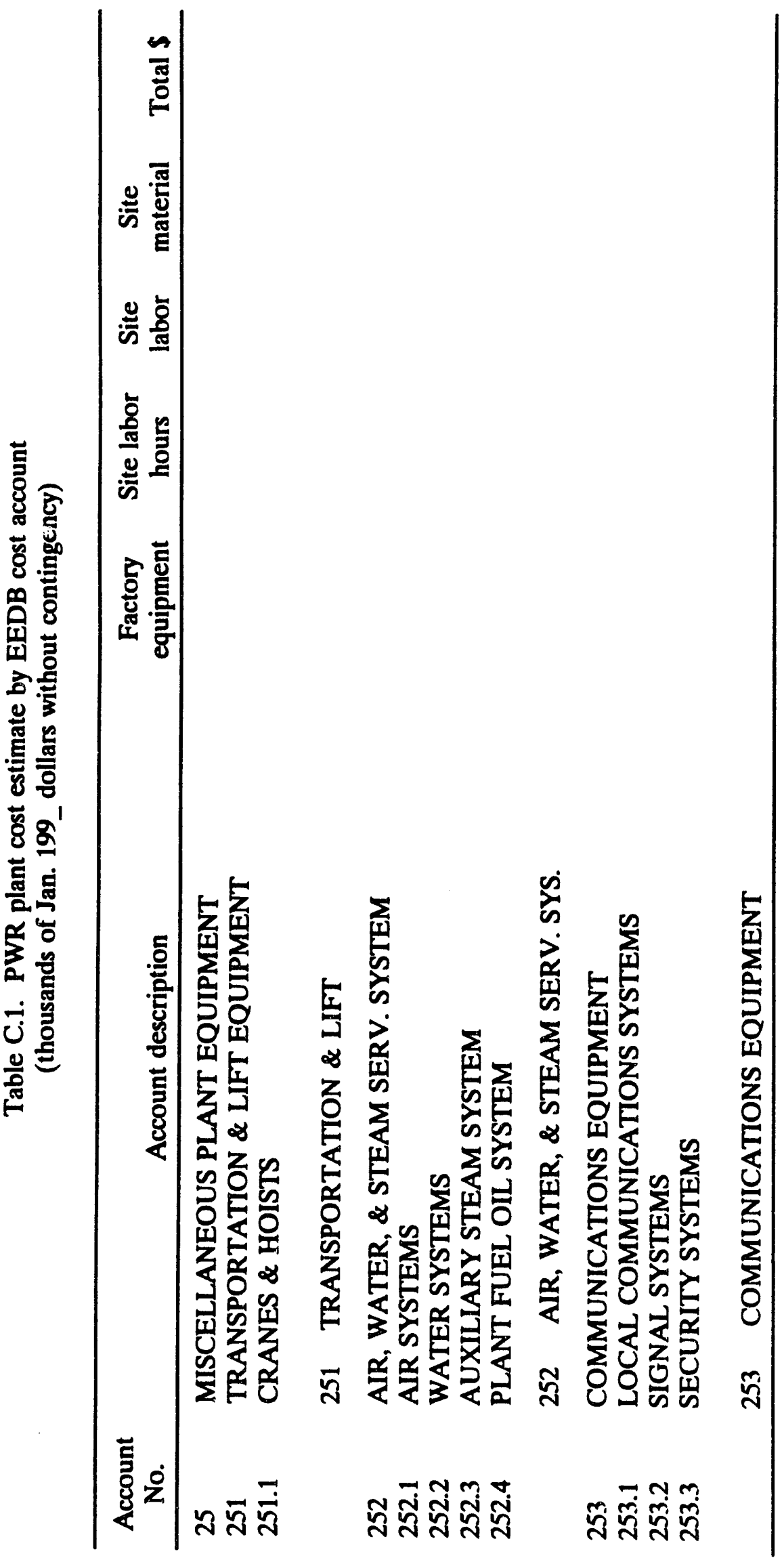




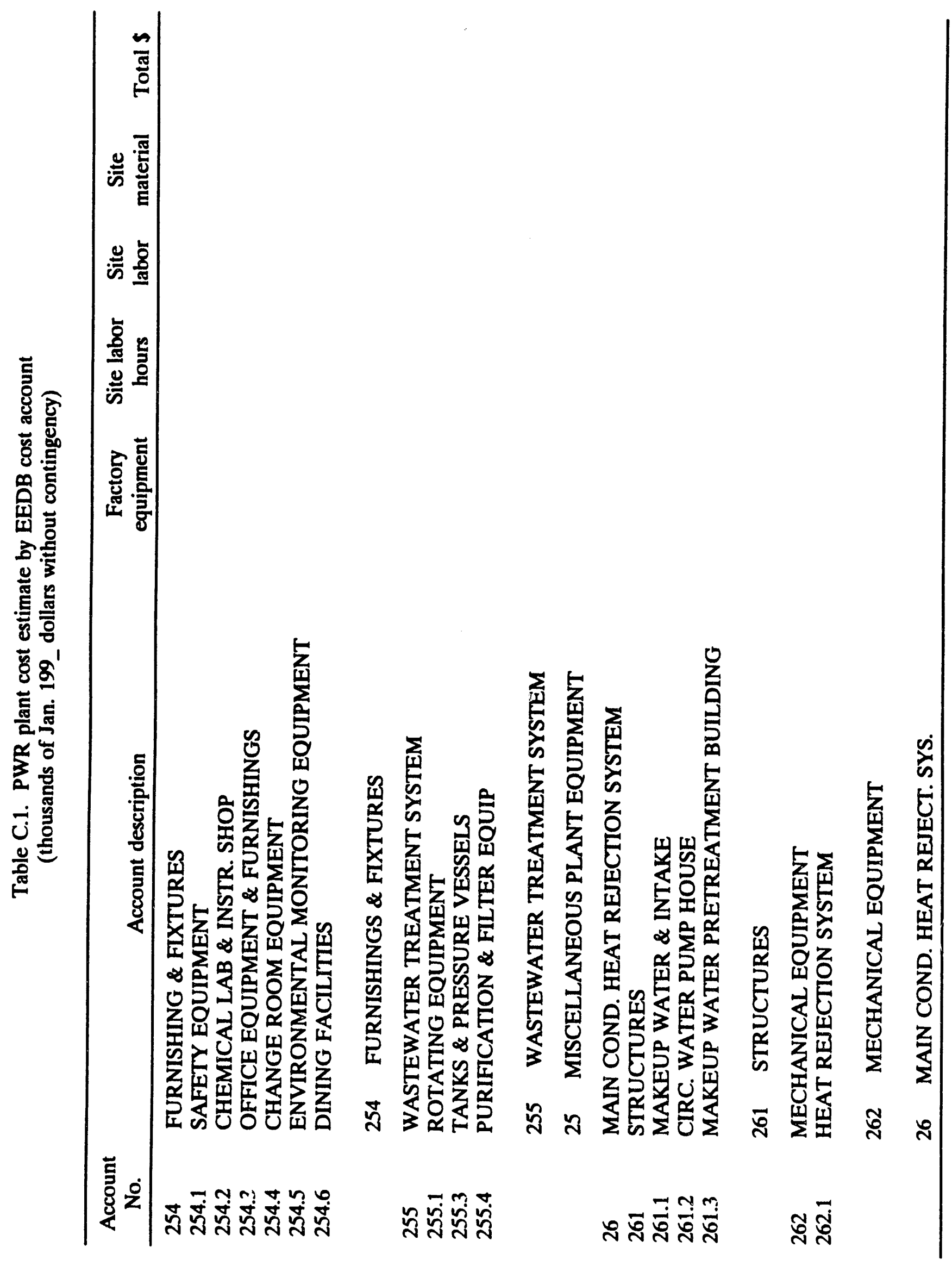




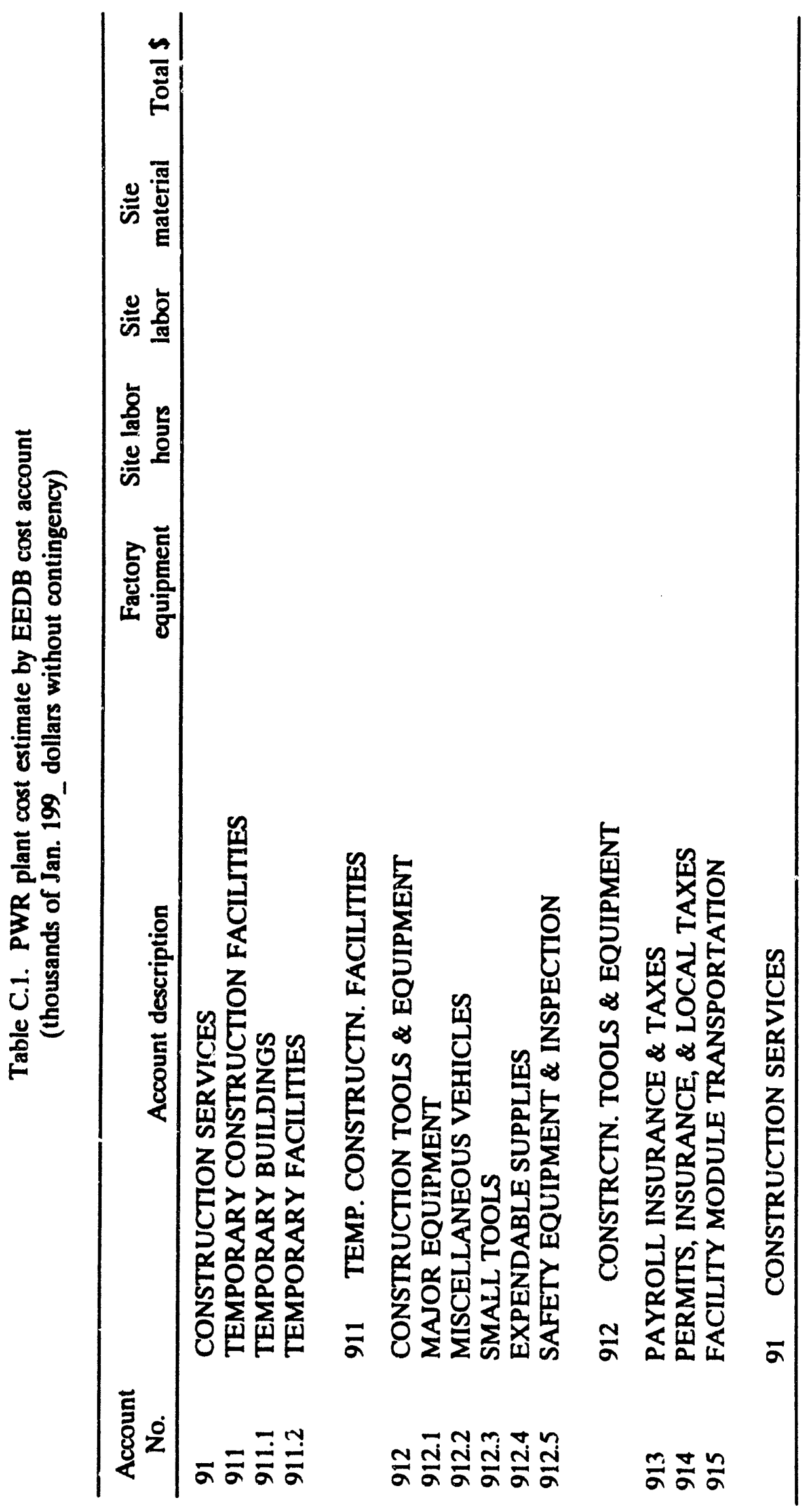




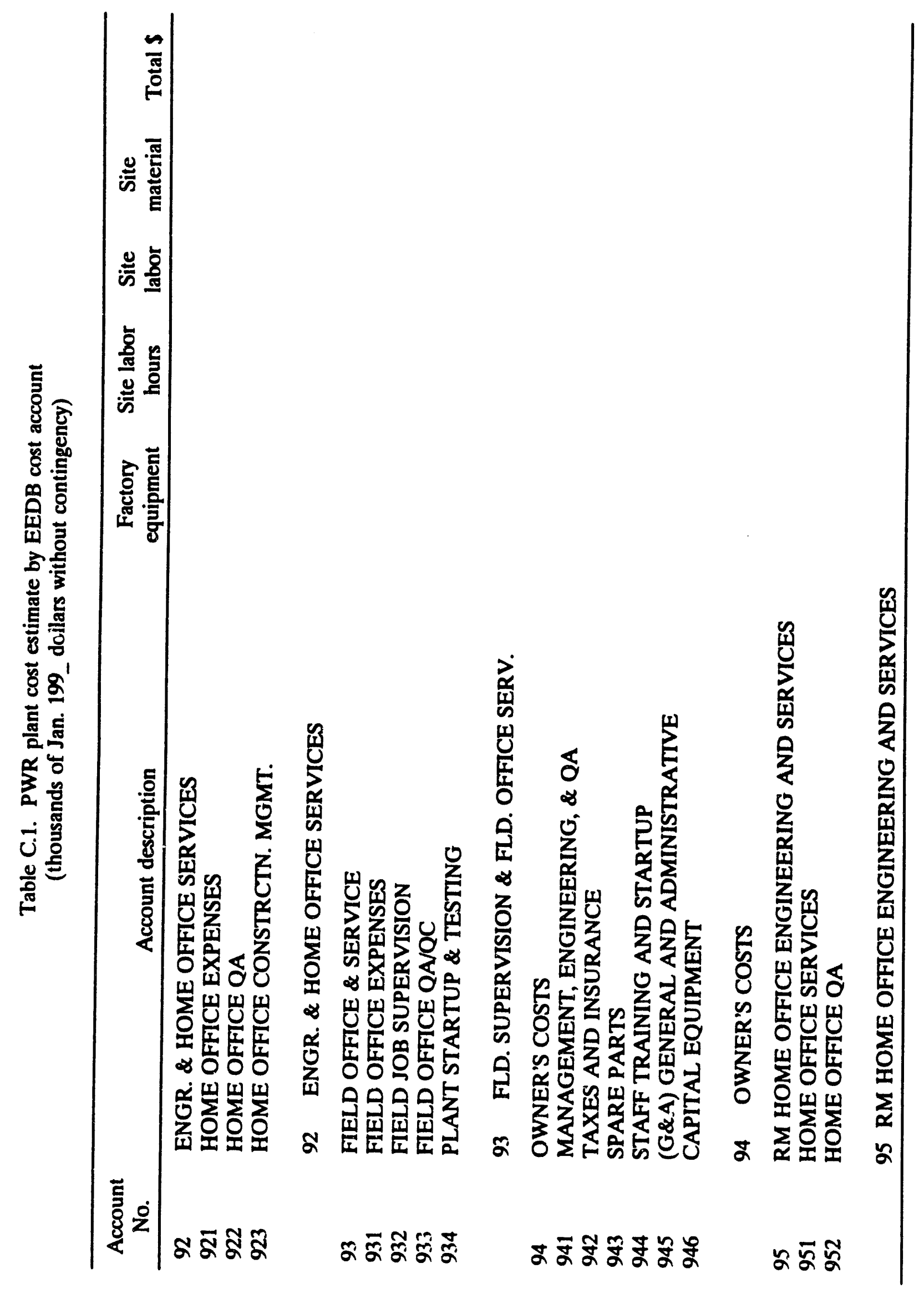


Appendix D

\section{LISTING OF SAMPLE FOAK TASKS}

\section{D.1 ENGINEERING AND MANAGEMENT}

- Prepare engineering specifications and drawings using generic site parameters as needed for design certification (layouts, design, manufacturing, installation, and interface control drawings).

- Prepare overall plant technical documents and maintenance and operating manuals.

- Prepare management plans, directives, and procedures.

- Prepare test plans, specifications, and procedures including definition of startup systems and turnover plans and procedures.

- Conduct analyses (stress, thermal, reliability, maintainability, availability, thermal hydraulics, loads, seismic failure mode analysis, and safety).

- Conduct design review meetings.

- Prepare verification and validation plans and conduct verification tests and analyses.

- Develop computer programs.

- Prepare vendor bid packages, including preparation of RFPs, bid evaluations, owner interface activities, and award of contract.

- Prepare plant construction model.

- Prepare modularization plan including Modular Fabrication/Acquisition strategies

- Obtain NRC certification for standard design.

\section{D2 EQUIPMENT MANUFACTURER}

- Develop tooling and fixtures for fabrication and assembly of components.

- Fabricate or purchase special component shipping fixtures and conditioning equipment.

- Conduct component development tests.

- Fabricate special test fixtures.

- Purchase or fabricate special test equipment.

- Fabricate or purchase any special component/material handling or transportation equipment used for equipment fabrication. 


\section{D.3 CONSTRUCTION}

- Prepare construction planning documentation.

- Fabricate any special forms or scaffolding required for construction of the first plant.

- Fabricate or purchase any special component and/or material handling or transportation equipment used on the first construction site. 


\section{Appendix E \\ SITE-RELATED ENGINEERING AND MANAGEMENT TASKS*}

(Applicable to all plants including prototype, first commercial, transitional, and NOAK plants)

- Prepare site-related engineering specifications and drawings (layouts, design, manufacturing, installation, and interface control drawings).

- Identify and retab nonsite drawings (design, manufacturing, installation, $a-d$ interface control drawings), technical documents, specifications, and manuals to show applicability to the Target Plant.

- Update and maintain technical work packages.

- Provide support at vendor's plant to witness factory acceptance testing.

- $\mathrm{St}^{*}$. port the constructor during plant construction and acceptance testing.

- Provide support to the Materials Review Board (MRB).

- Provide support as specifically requested to SAR (including emergency response) to show that the plant is identical in design.

- Support vendor bid evaluations and negotiations as requested by Procurement.

- Support the Constructor in the resolution of any field problems.

- Prepare site-specific licensing documents, such as ER and SAR.

- Repeat plant planning and scheduling and administrative, quality assurance, procurement, and industrial and public relations activities.

- Provide modularization schedule/sequencing plan.

- Provide engineering necessary to excavate and lay out the site for construction. This includes excavation drawings; dewatering calculations and analyses; and design and layout of access roads, parking lots, utilities, etc.

- Provide project management associated with the above tasks.

\footnotetext{
-All FOAK expenditures are separately listed in Appendix D.
} 


\section{Appendix F \\ DESCRIPTION OF EPRI STANDARD HYPOTHETICAL EAST/WEST CENTRAL SITE FOR NUCLEAR POWER PLANTS}

\section{F.1 GENERAL}

This site description provides the site and environmental data, derived from the EPRI standard site description for their East/West Central site. These data form the site-related bases of the criteria used in the EPRI requirements document for the siting of advanced nuclear plants including evaluation of the routine and accidental release of radioactive and other liquids and gases to the environment.

\section{F2 SITE-RELATED CRITERIA}

The site location is the EPRI Kenosha, Wisconsin site. This site is typical of power generation facilities located in middle America and having access to water and rail transportation. The site is assumed to be clear and level with no special problems: however, pile foundations may be required.

Site-related criteria are summarized below:

- Elevation

- Seismic zone

- Road

- Access to water - shipping

- Sources of water - makeup

- Limestone proximity

- Electric power
600 feet above mean sea level 1

1-mile road required

Lake Michigan; no docking facilities available Lake Michigan (Standard Lake Michigan water analysis) Available locally by truck $<50$ miles or by rail Available from the grid during startup; 1-mile transmission line required

\section{F.3 METEOROLOGICAL DATA}

Annual average ambient air conditions for material balances, thermal efficiencies, and equipment sizing are: 
- Dry bulb temperature

- Wet bulb temperature

- Atmospheric prsesure

- Maximum dry bulb temperature

- Maximum wet bulb temperature

Other meteorological data include:

- Minimum temperature (low ambient performance)

- Minimum temperature (freeze protection)

- Design conditions for rated output:

- Rainfall

- Wind velocity

- Wind direction $60^{\circ} \mathrm{F}$

$52^{\circ} \mathrm{F}$

14.4 psia

$95^{\circ} \mathrm{F}$

$75^{\circ} \mathrm{F}$

$20^{\circ} \mathrm{F}$

$-20^{\circ} \mathrm{F}$

31 in./yr

$10 \mathrm{mph}$

Southwest (summer conditions)

Weatherization criteria include the following:

- All exposed piping subject to freezing is electrically heat traced.

- Final coal and sorbent preparation, gas turbine, steam turbine, and water treatment facilities are located indoors.

Meteorlogical maximum data are given in Table F.1

\section{F.4 TECHNICAL DATA}

- Raw water is from Lo'ke Michigan: analysis is shown in Table F.2.

- Equipment sizing and sparing are based on achieving the target equivalent availability.

\section{F.5 PLANT SERVICES}

Plant services requirements include standards for power voltages, alternative power sources, compressed air, and cooling water.

- Power Voltages

- To line

- To yard

$230 \mathrm{kV}$

- Motors <250 hp

$13.8 \mathrm{kV}$

- Motors 250-3,000 hp

$480 \mathrm{~V}$

- Motors $>3000 \mathrm{hp}$ 
Table F.1. Envelope of Advanced Nuclear Plant Design Parameters

Maximum Ground Water Level

Maximum flood level ${ }^{a}$

Precipitation for roof design:

- Maximum rainfall ${ }^{b}$

- Maximum snow load

Ambient Design Temperatures,

- $1 \%$ Exceedance Values

Maximum:

Minimum:

- $0 \%$ Exceedance Values

(historic limit, excluding peaks $<2 \mathrm{hrs}$ )

Maximum:

Minimum:

Extreme Wind:

Basic wind speed ${ }^{c}$

Importance factors

Tornadof

- Maximum Tornado wind speed

- Translational velocity

- Radius

- Rate of pressure change

- Missile Spectra

- Missile velocity

- Missile Attitude
2 feet below grade

1 foot below plant grade

$19.4 \mathrm{in} . / \mathrm{h}$

(6.2 in./5 min)

$50 \mathrm{lb} / \mathrm{sq} \mathrm{ft}$

$100^{\circ} \mathrm{F}$ dry bulb/

$77^{\circ} \mathrm{F}$ coincident wet bulb

$80^{\circ} \mathrm{F}$ wet bulb (non-coincident)

$-10^{\circ} \mathrm{F}$

$115^{\circ} \mathrm{F}$ dry bulb/

$80^{\circ} \mathrm{F}$ coincident wet bulb

$81^{\circ} \mathrm{F}$ wet bulb (non-coincident)

$-40^{\circ} \mathrm{F}$

$110 \mathrm{mph}$

$1.0^{d} / 1.11^{e}$

$260 \mathrm{mph}$

$57 \mathrm{mph}$

$453 \mathrm{ft}$

$0.27 \mathrm{psi} / \mathrm{sec}$

spectrum 1 of SRP 3.5.1.4

35\% of Maximum Horiztonal Windspeed

$30 \mathrm{ft}$ above grade for large missiles; all evaluations for small missiles 
Table F.1 Continued

Soil Properties

- Minimum Bearing Capacity demand

$\geq 15 \mathrm{ksf}$

- Minimum shear wave velocity

$\geq 1000$ fps

- Liquefaction potential

none

Seismology

- SSE PGA

$0.30 \mathrm{~g}$

- SSE Design Response Spectra

per Reg. Guide 1.6

- SSE Time History

Envelope SSE Response spectra

Atmospheric Dispersion (Chi/Q)

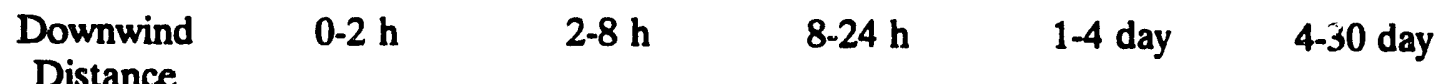

0.5 miles $\quad 1.0 \times 10^{-3}$

2.0 miles

$1.35 \times 10^{-4}$

$1.0 \times 10^{-4}$

$5.4 \times 10^{-5}$

$2.2 \times 10^{-5}$

'Probable maximum flood level as defined in ANSi/ANS 2.8-1983. Minimum value to be basis of standard plant design with previsions for accomodiation of flood levels up to maximum level.

${ }^{b}$ Maximum value for 1 hour, 1 square mile probable maximum precipitation (PMP) with ratio of 5 minutes to 1 hour PMP of 0.32 .

‘50 year recurrence level.

Importance factor to be used for non-safety-related structures as defined in ANSI A5811-1982.

Importance factor to be used for safety-related structures as defined in ANSI A58.1-1982.

One million year tornado recurrence interval with associated parameters based on ANSI/ANS 2.3-1983.

Values of bearing capabity and shear wave velocity are included to assure wide application of standard mat-type foundation design. Design must be evaluated against ranges of possible soil properties to verify wide application.

'PGA = Peak Ground Acceleration.

iFree-field at plant grade elevation. Envelopes all present U.S. nuclear sites except those on California coastline.

iThe Chi/Q values are to be used for the $10 \mathrm{CFR} 100$ dose evaluation. 
Table F.2. Raw water analysis

(Lake Michigan)

\begin{tabular}{|c|c|}
\hline Compound & $\begin{array}{c}\text { Analysis } \\
\text { (ppmw) }\end{array}$ \\
\hline Silica $\left(\mathrm{SiO}_{2}\right)$ & 1.8 \\
\hline Iron $(\mathrm{Fe})$ & 0.09 \\
\hline Manganese (Mn) & 0.0 \\
\hline Calcium (Ca) & 39.0 \\
\hline Magnesium (Mg) & 10.0 \\
\hline Sodium $(\mathrm{Na})$ & 3.3 \\
\hline Potassium (K) & 0.7 \\
\hline Carbonate $\left(\mathrm{CO}_{3}\right)$ & 0.0 \\
\hline Bicarbonate $\left(\mathrm{HCO}_{3}\right)$ & 132.0 \\
\hline Sulfate $\left(\mathrm{SO}_{4}\right)$ & 23.0 \\
\hline Chloride $(\mathrm{Cl})$ & 7.2 \\
\hline Fluoride (F) & 0.1 \\
\hline Nitrate $\left(\mathrm{NO}_{3}\right)$ & 0.0 \\
\hline \multicolumn{2}{|l|}{ Hardness as $\mathrm{CaCO}_{3}$ equivalents: } \\
\hline Total & 168 \\
\hline Noncarbonate & 30 \\
\hline Total suspended solids & 10 \\
\hline Total dissolved solids & 215 \\
\hline Color & 1 unit \\
\hline pH & 7.9 \\
\hline Turbidity & 0 \\
\hline $\begin{array}{l}\text { Specific conductance @ } 25^{\circ} \mathrm{C} \\
\text { (micrombos) }\end{array}$ & 275 \\
\hline
\end{tabular}

- Alternative Power Sources

- $250 \mathrm{~V}$ dc system with static inverters with normal feed via no break system for uninterruptible ac power for programmable logics, relay protections, operating circuits, and dc motors

- $125 \mathrm{~V}$ dc system for dc controls, instruments, emergency lighting, and annunicators

- Compressed Air

- Instrument air supplied at 80 to $100 \mathrm{psig}$ and $100^{\circ} \mathrm{F}$ (maximum), filtered and dried to $-40^{\circ} \mathrm{F}$ dew point

- Service air supplied at 80 to 100 psig and $100^{\circ} \mathrm{F}$ (maximum) 
- Cooling Water

- Mechanical draft cooling towers

- Design based on summer conditions ( $75^{\circ} \mathrm{F}$ wet bulb)

- Projected temperatures:

\begin{tabular}{lcc}
\hline \multicolumn{1}{c}{ Description } & $\begin{array}{c}\text { Maximum } \\
\left({ }^{\circ} \mathrm{F}\right)\end{array}$ & $\begin{array}{c}\text { Base } \\
\left({ }^{\circ} \mathrm{F}\right)\end{array}$ \\
\hline Ambient & 95 & 60 \\
Wet bulb & 75 & 52 \\
Temperature approach & 10 & 19 \\
Cold water & 85 & 71 \\
Temperature rise & 20 & $a$ \\
Return temperature & 105 & $a$ \\
\hline
\end{tabular}

To be established by maintaining the same cooling water circulation rate set by maximum ambient case.

\section{F.6 ENVIRONMENTAL REQUIREMENTS}

Sewage - Sewage generated on-site must receive primary and secondary treatment before discharge. Nonradioactive wastewater must be discharged in compliance with Environmental Protection Agency (EPA) effluent guidelines and standards as promulgated in 40 CFR 423.

Gaseous and Liquid Radioactive Wastes. Gaseous and liquid effluent releases at the site must comply with 10 CFR 20 and the intent of Appendix I of 10 CFR 50.

Solid Radioactive Wastes. On-site storage of solid radioactive wastes to permit radioactive decay is permissible, but ultimate disposal on-site is not planned.

Noise Limitations. In-plant noise levels must not exceed $90 \mathrm{dBA}$ for an 8-h exposure. Plant perimeter noise levels must not exceed $65 \mathrm{dBA}$ during the day and $55 \mathrm{dBA}$ during the night. 


\section{Appendix G \\ CONVERSION FROM NOMINAL TO CONSTANT DOLLARS}

Factors for converting nominal dollar levelized costs to constant dollars levelized costs are given in Tables G.1-G.9. These factors were calculated using the formula

$$
L C_{d} L C=(1+i)^{-L} \frac{\operatorname{CRF}\left(d_{0}, 30\right)}{\operatorname{CRF}(d, 30)} \times \frac{\sum_{j}^{j} 1 /(1+d)^{t-t_{1}}}{\sum_{j} 1 /\left(1+d_{0}\right)^{t_{-1}}}
$$

where

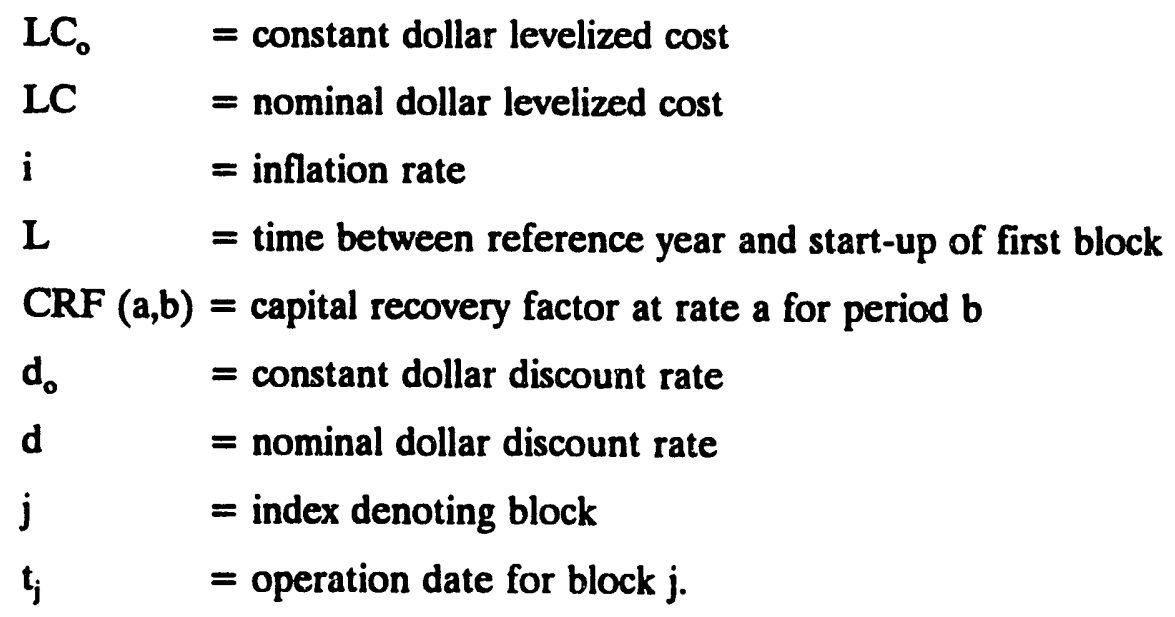

The cost factors are shown for a range of spacing between blocks and time between the reference years and the startup of the first block. Information is included for 1 to 4 block plants and for reference utility, industrial and IPP (high risk industrial) financing ground rules.

The ratio of the constant to nominal dollar capital recovery factors by itself is given in Table G.10 for a range of inflation rates and nominal costs of money. 
Table G.1. Levelized cost ratios ${ }^{a}$

Utility economics, 2-Block plant

\begin{tabular}{|c|c|c|c|c|c|c|c|}
\hline \multirow{2}{*}{$\begin{array}{l}\text { Time } \\
\text { until } \\
\text { startup } \\
\text { years }^{b}\end{array}$} & \multicolumn{7}{|c|}{ Spacing between blocks, yr } \\
\hline & $0.0^{c}$ & 0.5 & 1.0 & 1.5 & 2.0 & 2.5 & 3.0 \\
\hline 0.00 & 0.5898 & 0.5827 & 0.5760 & 0.5696 & 0.5635 & 0.5577 & 0.5522 \\
\hline 1.00 & 0.5617 & 0.5550 & 0.5486 & 0.5425 & 0.5367 & 0.5312 & 0.5259 \\
\hline 2.00 & 0.5349 & 0.5286 & 0.5225 & 0.5167 & 0.5111 & 0.5059 & 0.5008 \\
\hline 3.00 & 0.5095 & 0.5034 & 0.4976 & 0.4921 & 0.4868 & 0.4818 & 0.4770 \\
\hline 4.00 & 0.4852 & 0.4794 & 0.4739 & 0.4686 & 0.4636 & 0.4588 & 0.4543 \\
\hline 5.00 & 0.4621 & 0.4566 & 0.4513 & 0.4463 & 0.4415 & 0.4370 & 0.4326 \\
\hline 6.00 & 0.4401 & 0.4349 & 0.4298 & 0.4251 & 0.4205 & 0.4162 & 0.4120 \\
\hline 7.00 & 0.4191 & 0.4141 & 0.4094 & 0.4048 & 0.4005 & 0.3964 & 0.3924 \\
\hline 8.00 & 0.3992 & 0.3944 & 0.3899 & 0.3855 & 0.3814 & 0.3775 & 0.3737 \\
\hline 9.00 & 0.3802 & 0.3756 & 0.3713 & 0.3672 & 0.3633 & 0.3595 & 0.3559 \\
\hline 10.00 & 0.3621 & 0.3578 & 0.3536 & 0.3497 & 0.3460 & 0.3424 & 0.3390 \\
\hline 11.00 & 0.3448 & 0.3407 & 0.3368 & 0.3330 & 0.3295 & 0.3261 & 0.3228 \\
\hline 12.00 & 0.3284 & 0.3245 & 0.3208 & 0.3172 & 0.3138 & 0.3106 & 0.3075 \\
\hline 13.00 & 0.3128 & 0.3090 & 0.3055 & 0.3021 & 0.2988 & 0.2958 & 0.2928 \\
\hline 14.00 & 0.2979 & 0.2943 & 0.2909 & 0.2877 & 0.2846 & 0.2817 & 0.2789 \\
\hline 15.00 & 0.2837 & 0.2803 & 0.2771 & 0.2740 & 0.2711 & 0.2683 & 0.2625 \\
\hline 16.00 & 0.2702 & 0.2670 & 0.2639 & 0.2610 & 0.2582 & 0.2555 & 0.2530 \\
\hline 17.00 & 0.2573 & 0.2542 & 0.2513 & 0.2485 & 0.2459 & 0.2433 & 0.2409 \\
\hline 18.00 & 0.2451 & 0.2421 & 0.2394 & 0.2367 & 0.2342 & 0.2317 & 0.2294 \\
\hline 19.00 & 0.2334 & 0.2306 & 0.2280 & 0.2254 & 0.2230 & 0.2207 & 0.2185 \\
\hline 20.00 & 0.2223 & 5.2196 & 0.2171 & 0.2147 & 0.2124 & 0.2102 & 0.2081 \\
\hline 21.00 & 0.2117 & 0.2092 & 0.2068 & 0.2045 & 0.2023 & 0.2002 & 0.1982 \\
\hline 22.00 & 0.2016 & 0.1992 & 0.1969 & 0.1947 & 0.1926 & 0.1907 & 0.1888 \\
\hline 23.00 & 0.1920 & 0.1897 & 0.1875 & 0.1855 & 0.1835 & 2.1816 & 0.1798 \\
\hline 24.00 & 0.1829 & 0.1807 & 0.1786 & 0.1766 & 0.1747 & 0.1729 & 0.1712 \\
\hline 25.00 & 0.1742 & 0.1721 & 0.1701 & 0.1682 & 0.1664 & 0.1647 & 0.1631 \\
\hline 26.00 & 0.1659 & 0.1639 & 0.1620 & 0.1602 & 0.1585 & 0.1569 & 0.1553 \\
\hline 27.00 & 0.1580 & 0.1561 & 0.1543 & 0.1526 & 0.1509 & 0.1494 & 0.1479 \\
\hline 28.00 & 0.1504 & 0.1487 & 0.1469 & 0.1453 & 0.1438 & 0.1423 & 0.1409 \\
\hline 29.00 & 0.1433 & 0.1416 & 0.1399 & 0.1384 & 0.1369 & 0.1355 & 0.1342 \\
\hline 30.00 & 0.1365 & 0.1348 & 0.1333 & 0.1318 & 0.1304 & 0.1290 & 0.1278 \\
\hline
\end{tabular}

'Ratio of constant to nominal dollar levelized costs.

'Time between reference year and year of commercial operation of first block.

'Single block plant ratio is the same as zero lag time. 
144

Table G.2. Levelized cost ratios ${ }^{a}$

Utility economics, 3-Block plant

\begin{tabular}{rlllllll}
\hline \multirow{2}{*}{$\begin{array}{c}\text { Time } \\
\text { until }\end{array}$} & \multicolumn{7}{c}{ Spacing between blocks, yr } \\
startup \\
\cline { 2 - 8 } years
\end{tabular}

${ }^{9}$ Ratio of constant to nominal dollar levelized costs.

bTime between reference year and year of commercial operation of first block.

'Single block plant ratio is the same as zero lag time. 
145

Table G.3. Levelized cost ratios ${ }^{a}$

Utility economics, 4-Block plant

\begin{tabular}{|c|c|c|c|c|c|c|c|}
\hline \multirow{2}{*}{$\begin{array}{l}\text { Time } \\
\text { until } \\
\text { startup } \\
\text { years }\end{array}$} & \multicolumn{7}{|c|}{ Spacing between blocks, yr } \\
\hline & $0.0^{c}$ & 0.5 & 1.0 & 1.5 & 2.0 & 2.5 & 3.0 \\
\hline 0.00 & 0.5898 & 0.5827 & 0.5760 & 0.5696 & 0.5635 & 0.5577 & 0.5522 \\
\hline 1.00 & 0.5617 & 0.5550 & 0.5486 & 0.5425 & 0.5367 & 0.5312 & 0.5259 \\
\hline 2.00 & 0.5349 & 0.5286 & 0.5225 & 0.5167 & 0.5111 & 0.5059 & 0.5008 \\
\hline 3.00 & 0.5095 & 0.5034 & 0.4976 & 0.4921 & 0.4868 & 0.4818 & 0.4770 \\
\hline 4.00 & 0.4852 & 0.4794 & 0.4739 & 0.4686 & 0.4636 & 0.4588 & 0.4543 \\
\hline 5.00 & 0.4621 & 0.4566 & 0.4513 & 0.4463 & 0.4415 & 0.4370 & 0.4326 \\
\hline 6.00 & 0.4401 & 0.4349 & 0.4298 & 0.4251 & 0.4205 & 0.4162 & 0.4120 \\
\hline 7.00 & 0.4191 & 0.4141 & 0.4094 & 0.4048 & 0.4005 & 0.3964 & 0.3924 \\
\hline 8.00 & 0.3992 & 0.3944 & 0.3899 & 0.3855 & 0.3814 & 0.3775 & 0.3737 \\
\hline 9.60 & 0.3802 & 0.3756 & 0.3713 & 0.3672 & 0.3633 & 0.3595 & 0.3559 \\
\hline 10.00 & 0.3621 & 0.3578 & 0.3536 & 0.3497 & 0.3460 & 0.3424 & 0.3390 \\
\hline 11.00 & 0.3448 & 0.3407 & 0.3368 & 0.3330 & 0.3295 & 0.3261 & 0.3228 \\
\hline 12.00 & 0.3284 & 0.3245 & 0.3208 & 0.3172 & 0.3138 & 0.3106 & 0.3075 \\
\hline 13.00 & 0.3128 & 0.3090 & 0.3055 & 0.3021 & 0.2988 & 0.2958 & 0.2928 \\
\hline 14.00 & 0.2979 & 0.2943 & 0.2909 & 0.2877 & 0.2846 & 0.2817 & 0.2789 \\
\hline 15.00 & 0.2837 & 0.2803 & 0.2771 & 0.2740 & 0.2711 & 0.2683 & 0.2625 \\
\hline 16.00 & 0.2702 & 0.2670 & 0.2639 & 0.2610 & 0.2582 & 0.2555 & 0.2530 \\
\hline 17.00 & 0.2573 & 0.2542 & 0.2513 & 0.2485 & 0.2459 & 0.2433 & 0.2409 \\
\hline 18.00 & 0.2451 & 0.2421 & 0.2394 & 0.2367 & 0.2342 & 0.2317 & 0.2294 \\
\hline 19.0 & 0.2334 & 0.2306 & 0.2280 & 0.2254 & 0.2230 & 0.2207 & 0.2185 \\
\hline 20.00 & 0.2223 & 5.2196 & 0.2171 & 0.2147 & 0.2124 & 0.2102 & 0.2081 \\
\hline 21.00 & 0.2117 & 0.2092 & 0.2068 & 0.2045 & 0.2023 & 0.2002 & 0.1982 \\
\hline 22.00 & 0.2016 & 0.1992 & 0.1969 & 0.1947 & 0.1926 & 0.1907 & 0.1888 \\
\hline 23.00 & 0.1920 & 0.1897 & 0.1875 & 0.1855 & 0.1835 & 2.1816 & 0.1798 \\
\hline 24.00 & 0.1829 & 0.1807 & 0.1786 & 0.1766 & 0.1747 & 0.1729 & 0.1712 \\
\hline 25.00 & 0.1742 & 0.1721 & 0.1701 & 0.1682 & 0.1664 & 0.1647 & 0.1631 \\
\hline 26.00 & 0.1659 & 0.1639 & 0.1620 & 0.1602 & 0.1585 & 0.1569 & 0.1553 \\
\hline 27.00 & 0.1580 & $0.150 \mathrm{i}$ & 0.1543 & 0.1526 & 0.1509 & 0.1494 & 0.1479 \\
\hline 28.00 & 0.1504 & 0.1487 & 0.1469 & 0.1453 & 0.1438 & 0.1423 & 0.1409 \\
\hline 29.00 & 0.1433 & 0.1416 & 0.1399 & 0.1384 & 0.1369 & 0.1355 & 0.1342 \\
\hline 30.00 & 0.1365 & 0.1348 & 0.1333 & 0.1318 & 0.1304 & 0.1290 & 0.1278 \\
\hline
\end{tabular}

${ }^{a}$ Ratio of constant to nominal dollar levelized costs.

Time between refere ${ }^{\prime}$ ce year and year of commercial operation of first block.

'Single block plant ratio is the same as zero lag time. 
146

Table G.4. Levelized cost ratios ${ }^{a}$

Industrial economics, 2-Block plant

\begin{tabular}{|c|c|c|c|c|c|c|c|}
\hline \multirow{2}{*}{$\begin{array}{c}\text { Time } \\
\text { until } \\
\text { startup } \\
\text { years }^{b}\end{array}$} & \multicolumn{7}{|c|}{ Spacing between blocks, yr } \\
\hline & $0.0^{\circ}$ & 0.5 & 1.0 & 1.5 & 2.0 & 2.5 & 3.0 \\
\hline 0.00 & 0.6523 & 0.6446 & 0.6374 & 0.6307 & 0.6244 & 0.6186 & 0.6132 \\
\hline 1.00 & 0.6213 & 0.6139 & 0.6071 & 0.6007 & 0.5947 & 0.5892 & 0.5840 \\
\hline 2.00 & 0.5917 & 0.5847 & 0.5782 & 0.5721 & 0.5664 & 0.5611 & 0.5562 \\
\hline 3.00 & 0.5635 & 0.5569 & 0.5506 & 0.5448 & 0.5394 & 0.5344 & 0.5297 \\
\hline 4.00 & 0.5367 & 0.5303 & 0.5244 & 0.5189 & 0.5137 & 0.5089 & 0.5045 \\
\hline 5.00 & 0.5111 & 0.5051 & 0.4994 & 0.4942 & 0.4893 & 0.4847 & 0.4805 \\
\hline 6.00 & 0.4868 & 0.4810 & 0.4757 & 0.4706 & 0.4660 & 0.4616 & 0.4576 \\
\hline 7.00 & 0.4636 & 0.4581 & 0.4530 & 0.4482 & 0.4438 & 0.4396 & 0.4358 \\
\hline 8.00 & 0.4415 & 0.4363 & 0.4314 & 0.4269 & 0.4226 & 0.4187 & 0.4151 \\
\hline 9.00 & 0.4205 & 0.4155 & 0.4109 & 0.4066 & 0.4025 & 0.3988 & 0.3953 \\
\hline 10.00 & 0.4005 & 0.3957 & 0.3913 & 0.3872 & 0.3833 & 0.3798 & 0.3765 \\
\hline 11.00 & 0.3814 & 0.3769 & 0.3727 & 0.3688 & 0.3651 & 0.3617 & 0.3585 \\
\hline 12.00 & 0.3632 & 0.3590 & 0.3549 & 0.3512 & 0.3477 & 0.3445 & 0.3415 \\
\hline 13.00 & 0.3459 & 0.3419 & 0.3380 & 0.3345 & 0.3311 & 0.3281 & 0.3252 \\
\hline 14.00 & 0.3295 & 0.3256 & 0.3219 & 0.3185 & 0.3154 & 0.3124 & 0.3097 \\
\hline 15.00 & 0.3138 & 0.3101 & 0.3066 & 0.3034 & 0.3004 & 0.2976 & 0.2950 \\
\hline 16.00 & 0.2988 & 0.2953 & 0.2920 & 0.2889 & 0.2861 & 0.2834 & 0.2809 \\
\hline 17.00 & 0.2846 & 0.2813 & 0.2781 & 0.2752 & 0.2724 & 0.2699 & 0.2675 \\
\hline 18.00 & 0.2711 & 0.2679 & 0.2649 & 0.2621 & 0.2595 & 0.2570 & 0.2548 \\
\hline 19.00 & 0.2582 & 0.2551 & 0.2523 & 0.2496 & 0.4271 & 0.2448 & 0.2427 \\
\hline 20.00 & 0.2459 & 0.2430 & 0.2402 & 0.2377 & 0.2353 & 0.2331 & 0.2311 \\
\hline 21.00 & 0.2342 & 0.2314 & 0.2288 & 0.2264 & 0.2241 & 0.2220 & 0.2201 \\
\hline 22.00 & 0.2230 & 0.2204 & 0.2179 & 0.2156 & 0.2135 & 0.2115 & 0.2096 \\
\hline 23.00 & 0.2124 & 0.2099 & 0.2075 & 0.2053 & 0.2033 & 0.2014 & 0.1996 \\
\hline 24.00 & 0.2023 & 0.1999 & 0.1976 & 0.1956 & 0.1936 & 0.1918 & 0.1901 \\
\hline 25.00 & 0.1926 & 0.1904 & 0.1882 & 0.1862 & 0.1844 & 0.1827 & 0.1811 \\
\hline 26.00 & 0.1835 & 0.1813 & 0.1793 & 0.1774 & 0.1756 & 0.1740 & 0.1725 \\
\hline 27.00 & 0.1747 & 0.1727 & 0.1707 & 0.1689 & 0.1673 & 0.1657 & 0.1643 \\
\hline 28.00 & 0.1664 & 0.1644 & 0.1626 & 0.1609 & 0.1593 & 0.1578 & 0.1564 \\
\hline 29.00 & 0.1585 & 0.1566 & 0.1549 & 0.1532 & 0.1517 & 0.1503 & 0.1490 \\
\hline 30.00 & 0.1509 & 0.149 & 0.1475 & 0.1459 & 0.1445 & 0.1431 & 0.1419 \\
\hline
\end{tabular}

${ }^{a}$ Ratio of constant to nominal dollar levelized costs.

bime between reference year and year of commercial operation of first block.

'Single block plant ratio is the same as zero lag time. 
Table G.5. Levelized cost ratios ${ }^{a}$

Industrial economics, 3-Block plant

\begin{tabular}{|c|c|c|c|c|c|c|c|}
\hline \multirow{2}{*}{$\begin{array}{l}\text { Time } \\
\text { until } \\
\text { startup } \\
\text { years }\end{array}$} & \multicolumn{7}{|c|}{ Spacing between blocks, yr } \\
\hline & $0.0^{\circ}$ & 0.5 & 1.0 & 1.5 & 2.0 & 2.5 & 3.0 \\
\hline 0.00 & 0.0523 & 0.6372 & 0.6234 & 0.6109 & 0.5997 & 0.5897 & 0.5807 \\
\hline 1.00 & 0.6213 & 0.6068 & 0.5937 & 0.5818 & 0.5712 & 0.5616 & 0.5530 \\
\hline 2.00 & 0.5917 & 0.5779 & 0.5654 & 0.5541 & 0.5440 & 0.5348 & 0.5267 \\
\hline 3.00 & 0.5635 & 0.5504 & 0.5385 & 0.5277 & 0.5181 & 0.5094 & 0.5016 \\
\hline 4.00 & 0.5367 & 0.5242 & 0.5129 & 0.5026 & 0.4934 & 0.4851 & 0.4777 \\
\hline 5.00 & 0.5111 & 0.4992 & 0.4884 & 0.4787 & 0.4699 & 0.4620 & 0.4550 \\
\hline 6.00 & 0.4868 & 0.4755 & 0.4652 & 0.4559 & 0.4475 & 0.4400 & 0.4333 \\
\hline 7.00 & 0.4636 & 0.4528 & 0.4430 & 0.4342 & 0.4262 & 0.4191 & 0.4127 \\
\hline 8.00 & 0.4415 & 0.4313 & 0.4219 & 0.4135 & 0.4059 & 0.3991 & 0.3930 \\
\hline 9.00 & 0.4205 & 0.4107 & 0.4018 & 0.3938 & 0.3866 & 0.3801 & 0.3743 \\
\hline 10.00 & 0.4005 & 0.3912 & 0.3827 & 0.3751 & 0.3682 & 0.3620 & 0.3565 \\
\hline 11.00 & 0.3814 & 0.3725 & 0.3645 & 0.3572 & 0.3506 & 0.3448 & 0.3395 \\
\hline 12.00 & 0.3632 & 0.3548 & 0.3471 & 0.3402 & 0.3339 & 0.3283 & 0.3234 \\
\hline 13.00 & 0.3459 & 0.3379 & 0.3306 & 0.3240 & 0.3180 & 0.3127 & 0.3080 \\
\hline 14.00 & 0.3295 & 0.3218 & 0.3148 & 0.3086 & 0.3029 & 0.2978 & 0.2933 \\
\hline 15.00 & 0.3138 & 0.3065 & 0.2999 & 0.2939 & 0.2885 & 0.2836 & 0.2793 \\
\hline 16.00 & 0.2988 & 0.2919 & 0.2856 & 0.2799 & 0.2747 & 0.2701 & 0.2660 \\
\hline 17.00 & 0.2846 & 0.2780 & 0.2720 & 0.2665 & 0.2617 & 0.2573 & 0.2534 \\
\hline 18.00 & 0.2711 & 0.2648 & 0.2590 & 0.2539 & 0.2492 & 0.2450 & 0.2413 \\
\hline 19.00 & 0.2582 & 0.2521 & 0.2467 & 0.2418 & 0.2373 & 0.2333 & 0.2298 \\
\hline 20.00 & 0.2459 & 0.2401 & 0.2349 & 0.2303 & 0.2260 & 0.2222 & 0.2189 \\
\hline 21.00 & 0.2342 & 0.2287 & 0.2238 & 0.2193 & 0.2153 & 0.2117 & 0.2084 \\
\hline 22.00 & 0.2230 & 0.2178 & 0.2131 & 0.2088 & 0.2050 & 0.2016 & 0.1985 \\
\hline 23.00 & 0.2124 & 0.2074 & 0.2030 & 0.1989 & 0.1952 & 0.1920 & 0.1891 \\
\hline 24.00 & 0.2023 & 0.1976 & 0.1933 & 0.1894 & 0.1860 & 0.1828 & 0.1801 \\
\hline 25.00 & 0.1926 & 0.1882 & 0.1841 & 0.1804 & 0.1771 & 0.1741 & 0.1715 \\
\hline 26.00 & 0.1835 & 0.1792 & 0.1753 & 0.1718 & 0.1687 & 0.1658 & 0.1633 \\
\hline 27.00 & 0.1747 & 0.1707 & 0.1670 & 0.1636 & 0.1606 & 0.1579 & 0.1555 \\
\hline 28.00 & 0.1664 & 0.1625 & 0.1590 & 0.1558 & 0.1530 & 0.1504 & 0.1481 \\
\hline 29.00 & 0.1585 & 0.1548 & 0.1514 & 0.1484 & 0.1457 & 0.1433 & 0.1411 \\
\hline 30.00 & 0.1509 & 0.1474 & 0.1442 & 0.1414 & 0.1388 & 0.1364 & 0.1344 \\
\hline
\end{tabular}

'Ratio of constant to nominal dollar levelized costs.

'Time between reference year and year of commercial operation of first block.

'Single block plant ratio is the same as zero lag time. 
148

Table G.6. Levelized cost ratios ${ }^{\circ}$

Industrial economics, 4-Block plant

\begin{tabular}{|c|c|c|c|c|c|c|c|}
\hline \multirow{2}{*}{$\begin{array}{l}\text { Time } \\
\text { until } \\
\text { startup } \\
\text { years }\end{array}$} & \multicolumn{7}{|c|}{ Spacing between blocks, yr } \\
\hline & $0.0^{\circ}$ & 0.5 & 1.0 & 1.5 & 2.0 & 2.5 & 3.0 \\
\hline 0.00 & 0.6523 & 0.6299 & 0.6102 & 0.5929 & 0.5779 & 0.5649 & 0.5537 \\
\hline 1.00 & 0.6213 & 0.5999 & 0.5811 & 0.5646 & 0.5503 & 0.5380 & 0.5274 \\
\hline 2.00 & 0.5917 & 0.5713 & 0.5534 & 0.5378 & 0.5241 & 0.5123 & 0.5022 \\
\hline 3.00 & 0.5635 & 0.5441 & 0.5271 & 0.5122 & 0.4992 & 0.4880 & 0.4783 \\
\hline 4.00 & 0.5367 & 0.5182 & 0.5020 & 0.4878 & 0.4754 & 0.4647 & 0.4556 \\
\hline 5.00 & 0.5111 & 0.4935 & 0.4781 & 0.4645 & 0.4528 & 0.4426 & 0.4439 \\
\hline 6.00 & 0.4858 & 0.4700 & 0.4553 & 0.4424 & 0.4312 & 0.4215 & 0.4132 \\
\hline 7.00 & 0.4636 & 0.4477 & 0.4336 & 0.4214 & 0.4107 & 0.4014 & 0.3935 \\
\hline 8.00 & 0.4415 & 0.4263 & 0.4130 & 0.4013 & 0.3911 & 0.3823 & 0.3748 \\
\hline 9.00 & 0.4205 & 0.4060 & 0.3933 & 0.3822 & 0.3725 & 0.3641 & 0.3569 \\
\hline 10.00 & 0.4005 & 0.3867 & 0.3746 & 0.3640 & 0.3548 & 0.3468 & 0.3399 \\
\hline 11.00 & 0.3814 & 0.3683 & 0.3567 & 0.3466 & 0.3379 & 0.3303 & 0.3238 \\
\hline 12.00 & 0.3632 & 0.3507 & 0.3398 & 0.3301 & 0.3218 & 0.3145 & 0.3083 \\
\hline 13.00 & 0.3459 & 0.3340 & 0.3236 & 0.3144 & 0.3064 & 0.2996 & 0.2937 \\
\hline 14.00 & 0.3295 & 0.3181 & 0.3082 & 0.2994 & 0.2919 & 0.2853 & 0.2797 \\
\hline 15.00 & 0.3138 & 0.3030 & 0.2935 & 0.2852 & 0.2780 & 0.2717 & 0.2664 \\
\hline 16.00 & 0.2988 & 0.2886 & 0.2795 & 0.2716 & 0.2647 & 0.2588 & 0.2537 \\
\hline 17.00 & 0.2846 & 0.2748 & 0.2662 & 0.587 & 0.2521 & 0.2464 & 0.2416 \\
\hline 18.00 & 0.2711 & 0.2617 & 0.2535 & 0.2464 & 0.2401 & 0.2347 & 0.2301 \\
\hline 19.00 & 0.2582 & 0.2493 & 0.2415 & 0.2346 & 0.2287 & 0.2235 & 0.2191 \\
\hline 20.00 & 0.2459 & 0.2374 & 0.2300 & 0.2235 & 0.2178 & 0.2129 & 0.2087 \\
\hline 21.00 & 0.2342 & 0.2261 & 0.2190 & 0.2128 & 0.2074 & 0.2028 & 0.1988 \\
\hline 22.00 & 0.2230 & 0.2153 & 0.2086 & 0.2027 & 0.1975 & 0.1931 & 0.1893 \\
\hline 23.00 & 0.2124 & 0.2051 & 0.1986 & 0.1930 & 0.1881 & 0.1839 & 0.1803 \\
\hline 24.00 & 0.2023 & 0.1953 & 0.1892 & 0.1838 & 0.1792 & 0.1751 & 0.1717 \\
\hline 25.00 & 0.1926 & 0.1860 & 0.1802 & 0.175 & 0.176 & 0.1668 & 0.1535 \\
\hline 26.00 & 0.1835 & 0.1772 & 0.1716 & 0.1667 & 0.1625 & 0.1589 & 0.1557 \\
\hline 27.00 & 0.1747 & 0.1687 & 0.1634 & 0.1588 & 0.1548 & 0.1513 & 0.1483 \\
\hline 28.00 & 0.1665 & 0.1607 & 0.1556 & 0.1512 & 0.1474 & 0.1441 & 0.1413 \\
\hline 29.00 & 0.1585 & 0.1530 & 0.1482 & 0.1440 & 0.1404 & 0.1372 & 0.1345 \\
\hline 30.00 & 0.1509 & 0.1457 & 0.1412 & 0.1372 & 0.1337 & 0.1307 & 0.1281 \\
\hline
\end{tabular}

${ }^{a}$ Ratio of constant to nominal dollar levelized costs.

Time between reference year and year of commercial operation of first block.

'Single block plant ratio is the same as zero lag time. 
Table G.7. Levelized cost ratios ${ }^{a}$

IPP economics, 2-Block plant

\begin{tabular}{|c|c|c|c|c|c|c|c|}
\hline \multirow{2}{*}{$\begin{array}{l}\text { Time } \\
\text { until } \\
\text { startup } \\
\text { years }\end{array}$} & \multicolumn{7}{|c|}{ Spacing between blocks, yr } \\
\hline & $0.0^{\circ}$ & 0.5 & 1.0 & 1.5 & 2.0 & 2.5 & 3.0 \\
\hline 0.00 & 0.6330 & 0.6255 & 0.6184 & 0.6118 & 0.6055 & 0.5997 & 0.5943 \\
\hline 1.00 & 0.6028 & 0.5957 & 0.5890 & 0.5826 & 0.5767 & 0.5712 & 0.5660 \\
\hline 2.00 & 0.5741 & 0.5673 & 0.5609 & 0.5549 & 0.5493 & 0.5440 & 0.5390 \\
\hline 3.00 & 0.5468 & 0.5403 & 0.5342 & 0.5285 & 0.5231 & 0.5181 & 0.5133 \\
\hline 4.00 & 0.5208 & 0.5146 & 0.5088 & 0.5033 & 0.4982 & 0.4934 & 0.4889 \\
\hline 5.00 & 0.4960 & 0.4901 & 0.4845 & 0.4793 & 0.4745 & 0.4699 & 0.4656 \\
\hline 6.00 & 0.4723 & 0.4667 & 0.4615 & 0.4565 & 0.4519 & 0.4475 & 0.4434 \\
\hline 7.00 & 0.4498 & 0.4445 & 0.4395 & 0.4348 & 0.4304 & 0.4262 & 0.4223 \\
\hline 8.00 & 0.4284 & 0.4234 & 0.4186 & 0.4141 & 0.4099 & 0.4059 & 0.4022 \\
\hline 9.00 & 0.4080 & 0.4032 & 0.3986 & 0.3944 & 0.3903 & 0.3866 & 0.3831 \\
\hline 10.00 & 0.3886 & 0.3840 & 0.3797 & 0.3756 & 0.3718 & 0.3682 & 0.3648 \\
\hline 11.00 & 0.3701 & 0.3657 & 0.3616 & 0.3577 & 0.3541 & 0.3506 & 0.3474 \\
\hline 12.00 & 0.3525 & 0.3483 & 0.3444 & 0.3407 & 0.3372 & 0.3339 & 0.3309 \\
\hline 13.00 & 0.3357 & 0.3317 & 0.3280 & 0.3233 & 0.3211 & 0.3180 & 0.3151 \\
\hline 14.00 & 0.3197 & 0.3159 & 0.3123 & 0.3090 & 0.3058 & 0.3029 & 0.3001 \\
\hline 15.00 & 0.3045 & 0.3009 & 0.2975 & 0.2943 & 0.2913 & 0.2885 & 0.2858 \\
\hline 16.00 & 0.2900 & 0.2865 & 0.2833 & 0.2803 & 0.2774 & 0.2747 & 0.2722 \\
\hline 17.00 & 0.2762 & 0.2729 & 0.2698 & 0.2669 & 0.2642 & 0.2617 & 0.2593 \\
\hline 18.00 & 0.2630 & 0.2599 & 0.2570 & 0.2542 & 0.2516 & 0.2492 & 0.2469 \\
\hline 19.00 & 0.2505 & 0.2475 & 0.2447 & 0.2421 & 0.2396 & 0.2373 & 0.2352 \\
\hline 20.00 & 0.2386 & 0.2357 & 0.2331 & 0.2306 & 0.2282 & 0.2260 & 0.2240 \\
\hline 21.00 & 0.2272 & 0.2245 & 0.22220 & 0.2196 & 0.2174 & 0.2153 & 0.2133 \\
\hline 22.00 & 0.2164 & 0.2138 & 0.2114 & 0.2091 & 0.2070 & 0.2050 & 0.2031 \\
\hline 23.00 & 0.2061 & 0.2036 & 0.2013 & 0.1992 & 0.1971 & 0.1952 & 0.1935 \\
\hline 24.00 & 0.1963 & 0.1939 & 0.1918 & 0.1897 & 0.1878 & 0.1860 & 0.1843 \\
\hline 25.00 & 0.1869 & 0.1847 & 0.1826 & 0.1807 & 0.1788 & 0.1771 & 0.1755 \\
\hline 26.00 & 0.1780 & 0.1759 & 0.1739 & 0.1721 & 0.1703 & 0.1687 & 0.1671 \\
\hline 27.00 & 0.1695 & 0.1675 & 0.1656 & 0.1639 & 0.1622 & 0.1606 & 0.1592 \\
\hline 28.00 & 0.1615 & 0.1596 & 0.1578 & 0.1561 & 0.1545 & 0.1530 & 0.1516 \\
\hline 29.00 & 0.1538 & 0.1520 & 0.1502 & 0.1486 & 0.1471 & 0.1457 & 0.1444 \\
\hline 30.00 & 0.1465 & 0.1447 & 0.1431 & 0.1416 & 0.1401 & 0.1388 & 0.1375 \\
\hline
\end{tabular}

${ }^{a}$ Ratio of constant to nominal dollar levelized costs.

Time between reference year and year of commercial operation of first block.

'Single block plant ratio is the same as zero lag time. 
Table G.8. Levelized cost ratios ${ }^{a}$

IPP economics, 3-Block plant

\begin{tabular}{|c|c|c|c|c|c|c|c|}
\hline \multirow{2}{*}{$\begin{array}{c}\text { Time } \\
\text { until } \\
\text { startup } \\
\text { years }^{b}\end{array}$} & \multicolumn{7}{|c|}{ Spacing between blocks, yr } \\
\hline & $0.0^{c}$ & 0.5 & 1.0 & 1.5 & 2.0 & 2.5 & 3.0 \\
\hline 0.00 & 0.6330 & 0.6182 & 0.6046 & 0.5923 & 0.5810 & 0.5708 & 0.5616 \\
\hline 1.00 & 0.6028 & 0.5888 & 0.5759 & 0.5641 & 0.5534 & 0.5436 & 0.5348 \\
\hline 2.00 & 0.5741 & 0.4607 & 0.5484 & 0.5372 & 0.5270 & 0.5177 & 0.5093 \\
\hline 3.00 & 0.5468 & 0.5340 & 0.5223 & 0.5116 & 0.65019 & 0.4931 & 0.4851 \\
\hline 4.00 & 0.5208 & 0.5086 & 0.4974 & 0.4873 & 0.4780 & 0.4696 & 0.4620 \\
\hline 5.00 & 0.4960 & 0.4844 & 0.4738 & 0.4641 & 0.4552 & 0.4472 & 0.440 \\
\hline 6.00 & 0.4723 & 0.4613 & 0.4512 & 0.4420 & 0.4336 & 0.4259 & 0.4190 \\
\hline 7.00 & 0.4498 & 0.4393 & 0.4297 & 0.4209 & 0.4129 & 0.4057 & 0.3991 \\
\hline 8.00 & 0.4284 & 0.4184 & 0.4092 & 0.4009 & 0.3933 & 0.3863 & 0.3801 \\
\hline 9.00 & 0.4080 & 0.3985 & 0.3898 & 0.3818 & 0.3745 & 0.3679 & 0.3620 \\
\hline 10.00 & 0.3886 & 0.3795 & 0.3712 & 0.3636 & 0.3567 & 0.3504 & 0.3447 \\
\hline 11.00 & 0.3701 & 0.3614 & 0.3535 & 0.3463 & 0.3397 & 0.3337 & 0.3283 \\
\hline 12.00 & 0.3525 & 0.3442 & 0.3367 & 0.3298 & 0.3235 & 0.3178 & 0.3127 \\
\hline 13.00 & 0.3357 & 0.3278 & 0.3207 & 0.3141 & 0.3081 & 0.3027 & 0.2978 \\
\hline 14.00 & 0.3197 & 0.3122 & 0.3054 & 0.2991 & 0.2935 & 0.2883 & 0.2836 \\
\hline 15.00 & 0.3045 & 0.2974 & 0.2908 & 0.2849 & 0.2795 & 0.2746 & 0.2701 \\
\hline 16.00 & 0.2900 & 0.2832 & 0.2770 & 0.2713 & 0.2662 & 0.2615 & 0.2573 \\
\hline 17.00 & 0.2762 & 0.2697 & 0.2638 & 0.2584 & 0.2535 & 0.2490 & 0.2450 \\
\hline 18.00 & 0.2630 & 0.2569 & 0.2512 & 0.2461 & 0.2414 & 0.2372 & 0.2333 \\
\hline 19.00 & 0.2505 & 0.2446 & 0.2393 & 0.2344 & 0.2299 & 0.2259 & 0.2222 \\
\hline 20.00 & 0.2386 & 0.2330 & 0.2279 & 0.2232 & 0.2190 & 0.2151 & 0.2116 \\
\hline 21.00 & 0.2272 & 0.2219 & 0.2170 & 0.2126 & 0.2086 & 0.2049 & 0.2016 \\
\hline 22.00 & 0.2164 & 0.2113 & 0.2067 & 0.2025 & 0.1986 & 0.1951 & 0.1920 \\
\hline 23.00 & 0.2061 & 0.2013 & 0.1969 & 0.1928 & 0.1892 & 0.1858 & 0.1828 \\
\hline 24.00 & 0.1963 & 0.1917 & 0.1875 & 0.1836 & 0.1802 & 0.1770 & 0.1741 \\
\hline 25.00 & 0.1869 & 0.1826 & 0.1786 & 0.1749 & 0.1716 & 0.1686 & 0.1658 \\
\hline 26.00 & 0.1780 & 0.1739 & 0.1701 & 0.1666 & 0.1634 & 0.1605 & 0.1579 \\
\hline 27.00 & 0.1695 & 0.1656 & 0.1620 & 0.1586 & 0.1556 & 0.1529 & 0.1504 \\
\hline 28.00 & 0.1615 & 0.1577 & 0.1542 & 0.1511 & 0.1482 & 0.1456 & 0.1432 \\
\hline 29.00 & 0.1538 & 0.1502 & 0.1469 & 0.1439 & 0.1412 & 0.1387 & 0.1364 \\
\hline 30.00 & 0.1465 & 0.1430 & 0.1399 & 0.1370 & 0.1344 & 0.1321 & 0.1299 \\
\hline
\end{tabular}

${ }^{a}$ Ratio of constant to nominal dollar levelized costs.

bTime between reference year and year of commercial operation of first block.

'Single block plant ratio is the same as zero lag time. 
151

Table G.9. Levelized cost ratios ${ }^{\circ}$

IPP economics, 4-Block plant

\begin{tabular}{|c|c|c|c|c|c|c|c|}
\hline \multirow{2}{*}{$\begin{array}{c}\text { Time } \\
\text { until } \\
\text { startup } \\
\text { years }^{b}\end{array}$} & \multicolumn{7}{|c|}{ Spacing between blocks, yr } \\
\hline & $0.0^{\circ}$ & 0.5 & 1.0 & 1.5 & 2.0 & 2.5 & 3.0 \\
\hline 0.0 & 0.6330 & 0.6111 & 0.5916 & 0.5744 & 0.5591 & 0.5457 & 0.5340 \\
\hline 1.00 & 0.6028 & 0.5820 & 0.5634 & 0.5470 & 0.5325 & 0.5197 & 0.5086 \\
\hline 2.00 & 0.5741 & 0.5543 & 0.5366 & 0.5210 & 0.5071 & 0.4950 & 0.4843 \\
\hline 3.00 & 0.5468 & 0.5279 & 0.5111 & 0.4961 & 0.4830 & 0.4714 & 0.4613 \\
\hline 4.00 & 0.5208 & 0.5027 & 0.4867 & 0.4725 & 0.4600 & 0.4490 & 0.4393 \\
\hline 5.00 & 0.4960 & 0.4788 & 0.4635 & 0.4500 & 0.4381 & 0.4276 & 0.4184 \\
\hline 6.00 & 0.4723 & 0.4560 & 0.4415 & 0.4286 & 0.4172 & 0.4072 & 0.3985 \\
\hline 7.00 & 0.4498 & 0.4343 & 0.4205 & 0.4082 & 0.3973 & 0.3878 & 0.3795 \\
\hline 8.00 & 0.4284 & 0.4136 & 0.4004 & 0.3887 & 0.3784 & 0.3694 & 0.3614 \\
\hline 9.00 & 0.4080 & 0.3939 & 0.3814 & 0.3702 & 0.3604 & 0.3518 & 0.3442 \\
\hline 10.00 & 0.3886 & 0.3752 & 0.3632 & 0.3526 & 0.3432 & 0.3350 & 0.3278 \\
\hline 11.00 & 0.3701 & 0.3573 & 0.3459 & 0.3358 & 0.3269 & 0.3191 & 0.3122 \\
\hline 12.00 & 0.3525 & 0.3403 & 0.3294 & 0.3198 & 0.3113 & 0.309 & 0.2973 \\
\hline 13.00 & 0.3357 & 0.3241 & 0.3137 & 0.3046 & 0.2965 & 0.2894 & 0.2832 \\
\hline 14.00 & 0.3197 & 0.3086 & 0.2988 & 0.2901 & 0.2824 & 0.2756 & 0.2697 \\
\hline 15.00 & 0.3045 & 0.2939 & 0.2846 & 0.2763 & 02689 & 0.2625 & 0.2569 \\
\hline 16.00 & 0.2900 & 0.2799 & 0.2710 & 0.2631 & 0.2561 & 0.2500 & 0.2446 \\
\hline 17.00 & 0.2762 & 0.2666 & 0.2581 & 0.2506 & 0.2439 & 0.2381 & 0.2330 \\
\hline 18.00 & 0.2630 & 0.2539 & 0.2458 & 0.2387 & 0.2323 & 0.2268 & 0.2219 \\
\hline 19.00 & 0.2505 & 0.2418 & 0.2341 & 0.2273 & 0.2213 & 0.2160 & 0.2113 \\
\hline 20.00 & 0.2386 & 0.2303 & 0.2230 & 0.2165 & 0.2107 & 0.2057 & 0.2013 \\
\hline 21.00 & 0.2272 & 0.2193 & 0.2124 & 0.2062 & 0.2007 & 0.1959 & 0.1917 \\
\hline 22.00 & 0.2165 & 0.2089 & 0.2002 & 0.1963 & 0.1911 & 0.1865 & 0.1825 \\
\hline 23.00 & 0.2061 & 0.1990 & 0.1926 & 0.187 & 0.1820 & 0.1777 & 0.1739 \\
\hline 24.00 & 0.1963 & 0.1895 & 0.1834 & 0.1781 & 0.1734 & 0.1692 & 0.1656 \\
\hline 25.00 & 0.1869 & 0.1805 & 0.1747 & 0.1696 & 0.1651 & 0.1611 & 0.1577 \\
\hline 26.00 & 0.1780 & 0.1719 & 0.166 & 0.1615 & 0.1572 & 0.1535 & 0.1502 \\
\hline 27.00 & 0.1695 & 0.1637 & 0.1585 & 0.1538 & 0.1498 & 0.1462 & 0.1430 \\
\hline 28.00 & 0.1615 & 0.1559 & 0.1509 & 0.1465 & 0.1426 & 0.1392 & 0.1362 \\
\hline 29.00 & 0.1538 & 0.1485 & 0.1437 & 0.1395 & 0.1358 & 0.1326 & 0.1297 \\
\hline 30.00 & 0.1465 & 0.1414 & 0.1369 & 0.1329 & 0.1294 & 0.1263 & 0.1236 \\
\hline
\end{tabular}

"Ratio of constant to nominal dollar levelized costs.

bTime between reference year and year of commercial operation of first block.

'Single block plant ratio is the same as zero lag time. 
152

Table G.10. Levelized cost ratios ${ }^{\circ}$

Utility economics, 2-Block plant

\begin{tabular}{|c|c|c|c|c|c|c|c|c|c|}
\hline \multirow{2}{*}{$\begin{array}{c}\text { Nominal } \\
\text { discount } \\
\text { rate, } \\
\text { \%/year }\end{array}$} & \multicolumn{9}{|c|}{ Inflation rate, \%/yr } \\
\hline & 3.0 & 3.5 & 4.0 & 4.5 & 5.0 & 5.5 & 6.0 & 6.5 & 7.0 \\
\hline 5.00 & 0.681 & 0.635 & 0.592 & 0.551 & 0.512 & 0.476 & 0.441 & 0.408 & 0.377 \\
\hline 5.50 & 0.688 & 0.643 & 0.600 & 0.560 & 0.521 & 0.484 & 0.450 & 0.147 & 0.386 \\
\hline 6.00 & 0.694 & 0.650 & 0.608 & 0.568 & 0.530 & 0.493 & 0.459 & 0.426 & 0.395 \\
\hline 6.50 & 0.701 & 0.657 & 0.616 & 0.576 & 0.538 & 0.502 & 0.468 & 0.435 & 0.404 \\
\hline 7.00 & 0.707 & 0.665 & 0.624 & 0.584 & 0.547 & 0.511 & 0.477 & 0.444 & 0.413 \\
\hline 7.50 & 0.714 & 0.672 & 0.631 & 0.592 & 0.555 & 0.520 & 0.486 & 0.453 & 0.423 \\
\hline 8.00 & 0.720 & 0.679 & 0.639 & 0.601 & 0.564 & 0.528 & 0.495 & 0.463 & 0.432 \\
\hline 8.50 & 0.726 & 0.686 & 0.646 & 0.608 & 0.572 & 0.537 & 0.504 & 0.472 & 0.441 \\
\hline 9.00 & 0.732 & 0.692 & 0.654 & 0.616 & 0.580 & 0.546 & 0.513 & 0.481 & 0.450 \\
\hline 9.50 & 0.738 & 0.699 & 0.661 & 0.624 & 0.589 & 0.554 & 0.521 & 0.490 & 0.460 \\
\hline 10.00 & 0.744 & 0.705 & 0.668 & 0.632 & 0.597 & 0.563 & 0.530 & 0.499 & 0.469 \\
\hline 10.50 & 0.750 & 0.712 & 0.675 & 0.639 & 0.605 & 0.571 & 0.539 & 0.508 & 0.478 \\
\hline 11.00 & 0.755 & 0.718 & 0.682 & 0.646 & 0.612 & 0.579 & 0.547 & 0.517 & 0.487 \\
\hline 11.50 & 0.761 & 0.724 & 0.688 & 0.654 & 0.620 & 0.587 & 0.556 & 0.525 & 0.496 \\
\hline 12.00 & 0.766 & 0.730 & 0.695 & 0.661 & 0.627 & 0.595 & 0.564 & 0.634 & 0.505 \\
\hline 12.50 & 0.771 & 0.736 & 0.701 & 0.668 & 0.635 & 0.603 & 0.572 & 0.542 & 0.513 \\
\hline 13.00 & 0.776 & 0.741 & 0.707 & 0.674 & 0.642 & 0.611 & 0.580 & 0.551 & 0.522 \\
\hline 13.50 & 0.781 & 0.747 & 0.713 & 0.681 & 0.649 & 0.618 & 0.588 & 0.559 & 0.530 \\
\hline 14.00 & 0.785 & 0.752 & 0.719 & 0.687 & 0.656 & 0.625 & 0.596 & 0.567 & 0.539 \\
\hline 14.50 & 0.790 & 0.757 & 0.725 & 0.693 & 0.662 & 0.632 & 0.603 & 0.574 & 0.547 \\
\hline 15.00 & 0.794 & 0.762 & 0.730 & 0.699 & 0.669 & 0.639 & 0.610 & 0.582 & 0.555 \\
\hline 15.50 & 0.798 & 0.767 & 0.736 & 0.705 & 0.675 & 0.646 & 0.618 & 0.590 & 0.562 \\
\hline 16.00 & 0.802 & 0.771 & 0.741 & 0.711 & 0.681 & 0.653 & 0.624 & 0.597 & 0.570 \\
\hline 16.50 & 0.806 & 0.776 & 0.746 & 0.716 & 0.687 & 0.659 & 0.631 & 0.604 & 0.578 \\
\hline 17.00 & 0.810 & 0.780 & 0.751 & 0.722 & 0.693 & 0.665 & 0.638 & 0.611 & 0.585 \\
\hline 17.50 & 0.814 & 0.784 & 0.755 & 0.727 & 0.699 & 0.671 & 0.644 & 0.618 & 0.592 \\
\hline 18.00 & 0.817 & 0.788 & 0.760 & 0.732 & 0.704 & 0.677 & 0.651 & 0.624 & 0.599 \\
\hline 18.50 & 0.821 & 0.792 & 0.764 & 0.737 & 0.709 & 0.683 & 0.657 & 0.631 & 0.606 \\
\hline 19.00 & 0.824 & 0.796 & 0.768 & 0.741 & 0.715 & 0.688 & 0.663 & 0.637 & 0.612 \\
\hline 19.50 & 0.827 & 0.800 & 0.773 & 0.746 & 0.720 & 0.694 & 0.668 & 0.643 & 0.619 \\
\hline 20.00 & 0.830 & 0.803 & 0.777 & 0.750 & 0.724 & 0.699 & 0.674 & 0.649 & 0.625 \\
\hline
\end{tabular}
factor.

${ }^{a}$ Ratio of constant dollar capital recovery factor to nominal dollar capital recovery 


\section{APPENDIX H MOST LIKELY, EXPECTED, AND CONTINGENCY COSTS*}

Base construction cost is defined in Sect. 1.2 to be the "most likely" plant capital cost based on the direct and indirect costs only. Contingency, defined in Sect. 3, is a percentage of base construction cost when added results in the median cost estimate. The relevance of these terms and their interrelationship is described in this Appendix. The overall contingency factor will include an allowance for indeterminates.

\section{H.1 MOST LIKELY COST}

If there were several cost estimates for a given item, where the item has uncertainties and complexities associated with it, experience indicates that the distribution of the estimated costs would be typically like that shown in Fig. H.1 with a characteristically skewed to-theright shape. The highest point on the distribution corresponds to the estimate value for which there are the largest number of estimates. This value, known in statistics as the mode, is the most likely value (i.e., the most probable value or value with the highest probability).

For estimates determined in accordance with these guidelines, the base construction cost estimates are to represent the most likely cost value.

\section{H.2 EXPECTED COST AND CONTINGENCY}

Referring again to Fig. H.1, the median estimate value (estimate where there is an equal probability of actual costs being higher or lower) is greater than the most likely value. For the skewed distribution such as that shown in Fig. H.1, the median is where the area under the curve on both sides of the point is equal. The median is shown in Fig. H.2 to be the point were the cumulative probability is $50 \%$. For a normal distribution of costs (not skewed) the median cost $=$ the mode cost and a "0\%" contingency for that item would be assigned.

Based on Ref. 13. 
The total contingency cost for a power plant is the sum of the contributions for each system or component category and will also include the expected value of cost items not explicitly covered in the detailed estimate (allowance for indeterminates).

Thus, base cost plus contingency is intended to be a projected cost for which there is an equal probability of the actual cost being higher or lower. The greater the uncertainty, the higher the contingency assigned to develop a 50\% confidence level estimate. Obviously, if a $90 \%$ confidence level estimate is desired (90\% probability that the actual cost will be lower), a much higher contingency factor will be required to be applied to the "most likely" cost (1.85 vs. 1.2 in the Figs. H.1 and H.2 example).

Figures H.1 and H.2 were generated using a simple beta function with a "most likely" estimate of 100 , an optimistic estimate of 50 , and a pessimistic estimate of 270 . This data set results in an median value of 120 and a $20 \%$ contingency. 
Fig. H.1. Typical Capital Cost of Estimate Distribution (in presence of uncertainites).

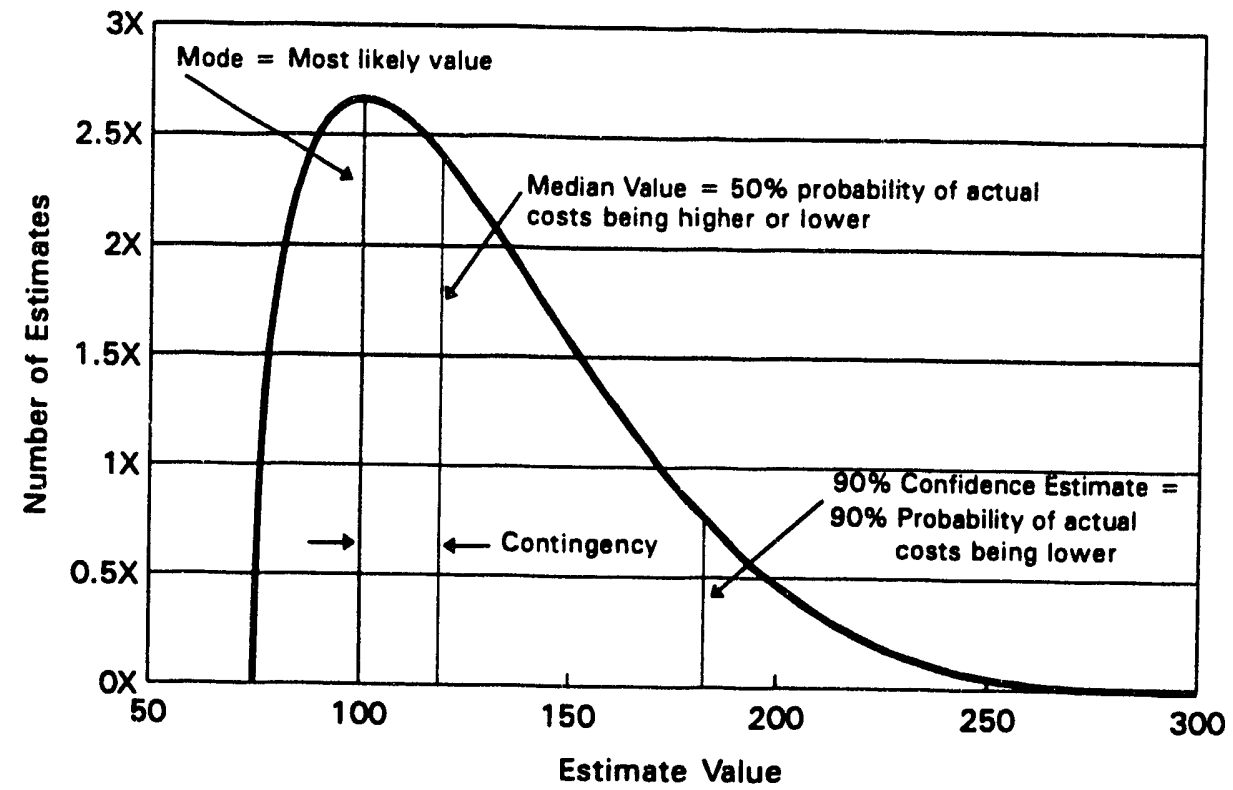

GCRAI

Fig. H.2. Typical Cost Estimate Cumulative Distribution (in presence of uncertainties).

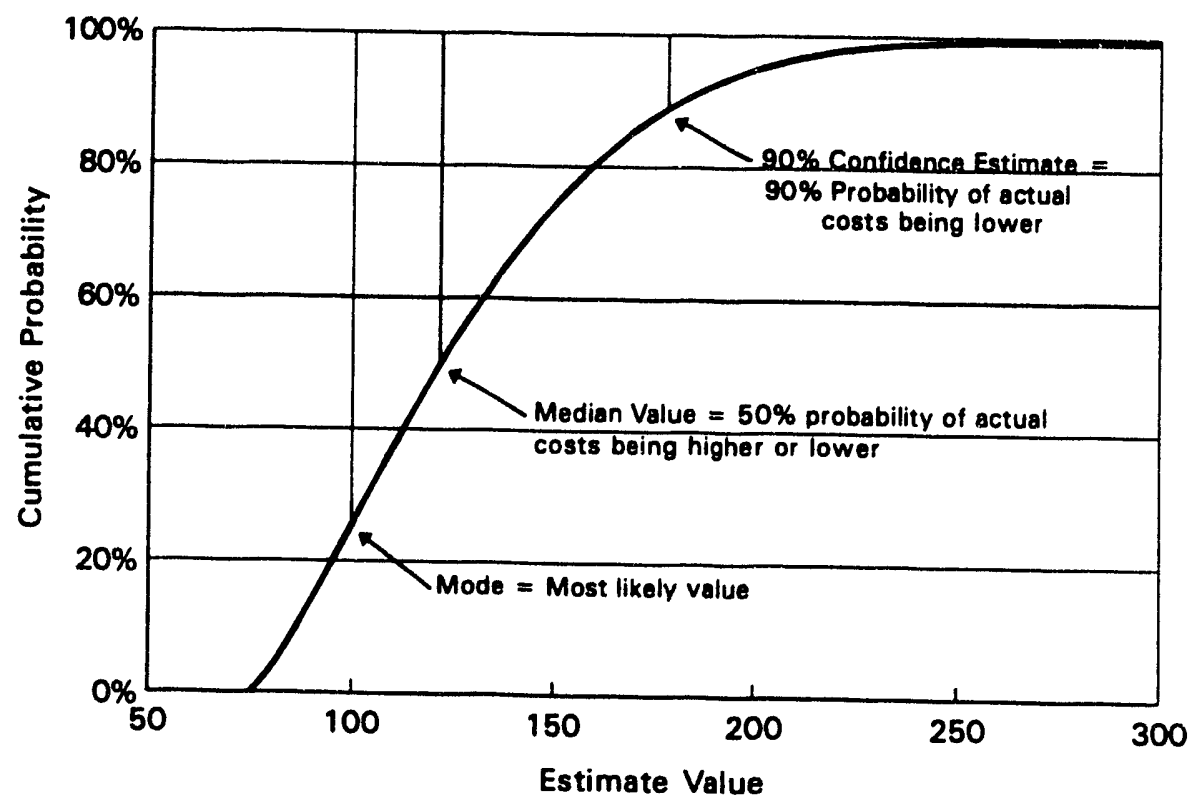

ecru2 
ORNL/TM-10071/R3

Dist. Category UC-520

\section{Internal Distribution}

1-5. J. G. Delene

6. C. A. Forsberg

7. E. C. Fox

8. L. C. Fuller

9. W. J. Fulkerson

10. F. J. Homan

11-15. C. R. Hudson II

16. H. Jones

17. J. E. Jones Jr.

18. D. L. Moses

19. R. L. Reid
20. P. L. Rittenhouse

21. J. O. Steigler

22. C. L. Wagner

23. J. D. White

24. K. A. Williams

25. ORNL Patent Office

26. Central Research Library

27. Document Reference Section

28-29. Laboratory Records Department

30. Laboratory Records (RC)

\section{External Distribution}

31. R. E. Allen, United Engineers \& Constructors Inc., P.O. Box 8223, Philadelphia, PA 19101

32. R. C. Berglund, General Electric Company, P.O. Box 530954, San Jose, CA 95153

33. L. F. Blankner, DOE-OR, P.O. Box 2001, Oak Ridge, TN 37831-8600.

34. G. C. Bramblett, General Atomics, P.O. Box 85608, San Diego, CA 92138

35. E. C. Brolin, U.S. Department of Energy, NE-2, Washington, DC 20545

36. H. Brusche, Westinghouse Electric Corporation, P.O. Box 355, Pittsbu gh, PA 15230

37. J. Caldwell, Gilbert/Commonwealth, Inc., P.O. Box 1498, Reading, PA 19603-1498

38. Sten Caspersson, ABB/CENP(M/S 9354-0422) 1000 Prospect Hill Road, Windsor, CT 06095-0500

39. Y. I. Chang, Bldg. 208, Argonne National Laboratory, 9700 S. Cass Ave., Argonne, IL 60439

40. R. Clausen, United Engineers and Constructors, 4500 Cherry Creek Drive, Box 5888, Denver, CO 80217

41. E. Cutting, Stone and Webster, 245 Summer St., Boston, MA 02107.

42. G. A. Davis, Combustion Engineering, Inc., P.O. Box 500, Windsor, CT 06095

43. David Dilling, Bechtel National Incorporated, P.O. Box 3965, San Francisco, CA 94119

44. E. J. Domaleski, Babcock \& Wilcox, P.O. Box 10935, Lynchburg, VA 24506-0935

45. C. S. Ehrman, Burns and Roe Company, Inc., 700 Kinderkamack Road, Oradell, NJ 07649.

46. S. El Safwany, U.S. Department of Energy, San Francsico Operations Office, 1333 Broadway, Oakland, CA 94612

47. G. P. Eysymontt, AutEx, Inc., 7213 Chestnut St., Chevy Chase, MD 20815 
48. L. K. Fletcher, DOE-Oak Ridge Operations, Oak Ridge, TN 37831

49. S. M. Franks, U.S. Department of Energy, NP-61, Washington, DC 20545

50. Mark Gielecki, U.S. Department of Energy EI-821, Washington, DC 20545

51. S. Golan, Bechtel National Incorporated, P.O. Box 3965, San Francisco, CA 94119

52. F. J. Goldner, U.S. Department of Energy, NE-45, Washington, DC 20545

53. J. N. Gonzaga, AutEx, Inc., 130 W. 67 St., Suite 1C, New York, NY 10023

54. J. Griffith, U.S. Department of Energy, NE-40, Washington, DC 20545

55. N. Grossman, U.S. Department of Energy, NE-45, Washington, DC 20545

56. C. O. Gruber, Gilbert/Commonwealth, Inc., P.O. Box 1498, Reading, PA 19603-1498

57. P. B. Hemmig, U.S. Department of Energy, NE-462, Washington, DC 20545

58. B. A. Hutchins, General Electric Company, P.O. Box 530954, San Jose, CA 95153

59. M. P. LaBar, General Atomics, P.O. Box 85608, San Diego, CA 92138

60. E. G. Lazur, U.S. Department of Energy, DP-66, Washington, DC 20545

61. D. J. McGoff, U.S. Department of Energy, NE-40, Washington, DC 20545

62. L. D. Mears, Gas-Cooled Reactor Associates, 10240 Sorrento Valley Rd., San Diego, CA 92121

63. Ray R. Mills, MHTGR-PDCO-East, MEREX, Inc., 3206 Tower Oak Blvd., Ste. 300, Rockville, MD 20852

64. James Mottley, Westinghouse Electric Corporation, P.O. Box 355, Pittsburgh, PA 15230

65. J. D. Nulton, U.S. Department of Energy, NE-40, Washington, DC 20545

66. P. Overholt, U.S. Department of Energy, NE-44, Washington, DC 20545

67. Walter Parker, Stone and Webster, 245 Summer St., Boston, MA 02107

68. G. R. Pause, Gas-Cooled Reactor Associates, 10240 Sorrento Valley Rd., San Diego, CA 92121

69. G. Pavlenco, United Engineers \& Constructors Inc., P.O. Box 8223, Philadelphia, PA 19101

70. J. E. Quinn, General Electric Company, P.O. Box 530954, San Jose, CA 95153

71. E. Rodwell, Electric Power Research Institute, P.O. Box 10412, Palo Alto, CA 94303

72. H. H. Rohm, U.S. Department of Energy, NE-40, Washington, DC 20545

73. S. Rosen, U.S. Department of Energy, NE-45, Washington, DC 20545

74. L. N. Salerno, General Electric Company, P.O. Box 530954, San Jose, CA 95153

75. C. R. Snyder, Bechtel National Incorporated, P.O. Box 3965, San Francisco, CA 94119

76. John Stamos, U.S. Department of Energy, NE-44, Washington, DC 20545

77. I. Taylor, General Electric Company, P.O. Box 530954, San Jose, CA 95153

78. M. L. Thompson, General Electric Company, P.O. Box 530954, San Jose, CA 95153

79. T. A. Werner, U.S. Department of Energy, NE-44, Washington, DC 20545

80. John Williams, U.S. Department of Energy, NE-40, Washington, DC 20545

81. P. M. Williams, U.S Department of Energy, NE-45, Washington, DC 20545

82. R. S. Wood, U.S. Nuclear Regulatory Commission, 11555 Rockville Pike, Rockville, MD 20852 
83. Office of Assistant Manager for Energy Research and Development, DOE-Oak Ridge Operations, Oak Ridge, TN 37831

84-152. Given distribution as shown in DOE/OSTI-4500-R75 under category UC-520 (General Reactor Technology) 

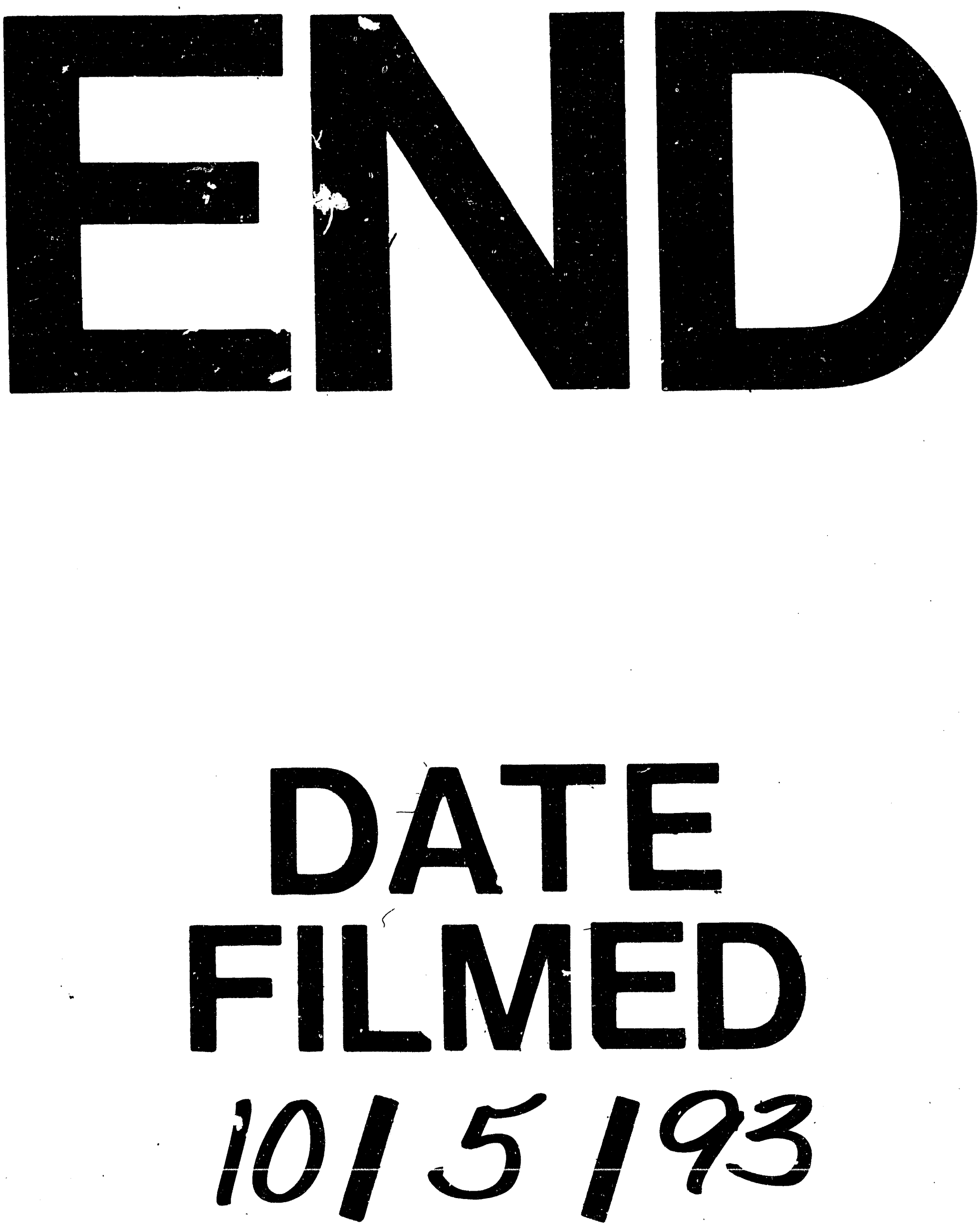

1 
